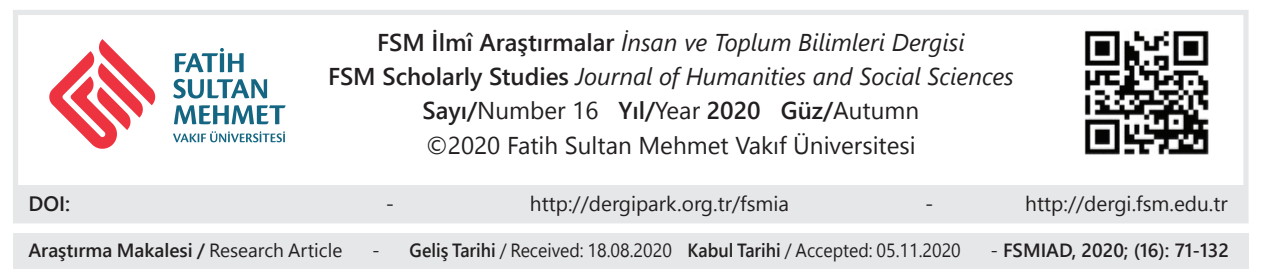

\title{
Suriye İç Savaşındaki Afganlılar: İran Hazara Fatımiyyun Tugayı Mehmet Erkan Kıllığlu*
}

\section{Öz}

Eski Sovyet Cumhuriyetlerinde bağımsızlık sonrası dönemde iktidarda kalmaya devam eden Sovyet Nomenklatura sisteminin bakiyesi olan kadroları tasfiye etmek için başlatılan Renki Devrimler'in yansımaları ilk olarak Arap Baharı olayları kapsamında Tunus'ta ortaya çıktı. Tunus'ta başlayan bu istikrarsızlık dalgası 2011 yılında Suriye'ye de ulaştı. Ülkede başlayan halk ayaklanması baskıcı Esed rejiminin geleceğini tehlikeye soktu; rejimin yönetme gücünün kaybolmaya başlaması sonucunda Esed rejimi özellikle kırsal bölgelerde kontrolü kaybetti. Suriye rejiminin Ortadoğu'daki en önemli destekçilerinden birisi olan İran ülkedeki bu kötü gidişatı durdurmak için Esed rejimine örtülü destek sağlamaya başladı. Bu destek sayesinde İran, Irak ve Suriye'den geçerek Lübnan'da Akdeniz'e ulaşan kara köprüsünün varlığını güvenceye almaya çalışıyordu. Ancak Suriye muhalefetinin başarısı Esed rejimi ile İran'ın kara köprüsünü tehdit ediyordu. İran'ın kurduğu bu kara köprüsü stratejik açıdan hayati önemde idi çünkü bu yolla İran, İsrail'i Lübnan ve Filistin'de meşgul eden kendisine yakın gruplara personel ve malzeme desteği sağlayabiliyordu. Ancak İran'ın sağladığı örtülü destek yeterli olmadı. Bunun üzerine İran Suriye'deki dahlini arttırmak ve Devrim Muhafızları ve Kudüs Gücü gibi resmi güçlerini seferber etmek zorunda kaldı. Bu resmi güçlere ek olarak, İran Şii gö-

\footnotetext{
* Dr., Çanakkale Onsekiz Mart Üniversitesi, Çanakkale/Türkiye, mehmeterkan@comu.edu.tr, orcid.org/0000-0002-3146-2609
} 
nüllüleri de seferber etme yoluna gitti. İran, Irak’ta bir hava saldırısı sırasında öldürtülen Kasım Süleymani tarafından geliştirilen ve İran dışındaki başka ülkelerden devşirilen Şii gönüllülerin İran adına vekâlet savaşlarında kullanılması stratejisi kapsamında, Afganistan'ın sahipsiz topluluklarından birisi olan Afgan Hazaraları Suriye'de kendi namına savaştırmaya başladı.

Anahtar Kelimeler: Hazaralar, Fatimiyyun Tugay1, Afganistan.

\section{Afghans in Syrian Civil War: Iran's Hazara Fatemiyoun Division}

\section{Abstract}

Because of the unwanted effects of Color Revolutions that shook the former Soviet Republics, which aims to topple remnants old Soviet Nonemclatura system, Arap Spring incidents first broke in Tunisia. That wave of unrest reaches to Syria in 2011. The popular unrest in Syria puts the existing oppressiand Al-Assad's government in close danger. As Esed's regime power and the ability to governing the country began to erode, Al-Assad's government lose control in the country, especially in the rural countryside. In order to stop that negative pattern, Iran, one the top supporter of the Syrian Baathist Regime, take the initiative and provide meaningful but covert support. With the help of that support Iran tried to ensure existence of the land bridge, passing througt Iraq to Syria and then reaches to Mediterranean in Lebanon. But growing success and performence of the Syrian Opposition put existence of Syrian Regime and Iran's Land Bridge in danger. This Land Bridge is strategically important because with the help of that land bridge Iran can provide personel and material support to allied factions which are disturbing Israel in Lebanon and Palestine and keeps Israel busy. As it turned out that this covert support would not be enough, Iran was forced to decide to take advantage of the official forces such as the Iranian Revolutionary Guards and the Quds Force. Other than offical organizations Iran implements the strategy of using the Shiite volunteers recruited from other countries other than Iran in the proxy wars. Strategy of using Shia volunteers in proxy wars developed by Kasım Süleymani, who was killed during an air attack in Iraq. The Afghan Hazaras, one of the most exploited communities of the Afghanistan, started to fight on the behalf of Iran.

Keywords: Hazaras, Fatemiyoun Division, Afghanistan. 


\section{Giriş}

Suriye İç Savaşı'na müdahil olan bölgesel güçlerden biri -kendisi başlarda bu dahlini inkar etse de- İran'dır. ${ }^{1}$ Çok az kişinin İran'ın Suriye'deki iç savaşta dahli konusunda şüphesi vardı. Çünkü İran ile Suriye arasında geçmişi İran Devrimi’ne dayanan iyi ilişkiler mevcuttur. 1979 yılında İran'da Devrim olduğu sırada, Suriye teknik olarak savaş halinde olduğu İsrail'le Mısır'ın barış antlaşması yaparak aradan çekilmesi nedeniyle yalnız kalmıştı. Aynı dönemde Suriye ile Irak arasındaki yaşanan gerginlik de bu olumsuz duruma katkıda bulunuyordu. $\mathrm{Bu}$ sıkıntılı dönemde İran'daki Batı/ABD yanlısı monarşinin (Şahllk) devrilmesi ve yerine İsrail/Siyonizm karşıtı, anti-emperyalist söylemi olan ve Filistin davasını sahiplenen bir yönetimin gelmesi Suriye'nin rahat nefes almasını sağlamıştır. Bu saiklerin etkisiyle Suriye rejimi İran'daki bu yeni yönetimi tanıyan ve destekleyen ilk Arap ülkesi olmuştur. Öyle ki dönemin Suriye Dışişleri Bakanı Abdulhalim Haddam, İran Devrimi'ni “20. yüzyıl tarihindeki en önemli olay” olarak nitelendirmiştir. ${ }^{2}$ Ek olarak İran, Karim Sadjadpour'un analizinde değindiği üzere, Suriye ile olan ittifakını kendi yüksek stratejisinin önemli bir bileşeni olarak görmektedir. Suriye, İran'ın Ortadoğu'daki stratejik çıkarları açısından önemli bir ülkedir ve uzunca bir süredir de bölgedeki en iyi müttefiklerinden biridir. Suriye, İran'ın Lübnan Hizbullah'1, Hamas vb. irtibat halinde olduğu örgütlere erişimini sağlamaktadır. İran, bu örgütlere Suriye'nin sağladığı kara bağlantısı sayesinde insan, para, silah ve teçhizat gönderebilmekte ve rakip olarak gördüğü ülkeleri meşgul edebilmektedir. ${ }^{3}$

Ortadoğu'da Esed rejimine açık destek veren ve iç savaşın en aktif tarafı olduğu artık açıkça belli olan ülke ise şüphesiz Suriye sorununu kendi iç meselesi olarak gören İran'dır. Suriye'deki İran müdahalesinin kapsamı 2013 yılı Şubat ayında İranlı Tuğgeneral Hasan Şateri, Beyrut'a giderken Şam kırsalında suikaste kurban gitmesi ile ortaya çıkmıştır. Suikaste kurban giden Şateri, İran

1 Robert F. Worth, "Effort to Rebrand Arab Spring Backfires in Iran", The New York Times, 2 Şubat 2012, s. 1.

2 Melih Kazdal, “İran'ın Arap Baharı Sonrası Suriye Politikasını Anlamak”, Artuklu Kaime Uluslararası İktisadi ve İdari Araştırmalar Dergisi, cilt 1, sayı 1, 2018, s. 2. Ayrıca bkz. Bayram Sinkaya, "İran-Suriye İlişkileri ve Suriye'de Halk İsyanı”, Ortadoğu Analiz, cilt 3, say1 33, Eylül 2011, s. 39. Benzer görüş için bkz. Ali Ansari - Aniseh Bassiri Tabrizi, "The View from Tehran", Understanding Iran's Role in the Syrian Conflict içinde (3-9), ed. Aniseh Bassiri Tabrizi ve Raffaello Pantucci, Londra, Royal United Services Institute for Defense and Security Studies, Occasional Paper, Ağustos 2016, s. 3.

3 Will Fulton - Joseph Holliday - Sam Wyer, Iranian Strategy in Syria, A Joint Report by AEI's Critical Threats Project \& Institute for the Study of War, Institute for the Study of War, May1s, 2013, s. 9. 
Devrim Muhafızları Kudüs Gücü’nün kıdemli komutanlarındandı ve 2006 yılından beri Lübnan'da bulunuyordu. Lübnan'dan önce de Afganistan ve Irak'ta bulunmuştu. ${ }^{4}$ Suriye'de bulunması İran'ın ülkeye verdiği önemin göstergesi olarak yorumlanmıştı. Şateri suikastin ortaya çıkardığı üzere Suriye, İran'ın bölgesel nüfûzunu artırmak amacıyla belli bir süredir 'yatırım yaptığı' ve özel önem verdiği bir ülkeydi. Taraflar arasında zaman zaman fikir ayrılıkları ortaya çıkmış olsa da Tahran, Suriye üzerinde etki kurmaya ve Beşşar Esed rejiminin ayakta tutmaya büyük önem veriyordu. Çünkü İran'a göre Suriye İç Savaşı, bölgede aslında kendisine karşı yapılmak istenen saldırının bir parçası ve ön hazırlığı idi. İran ayrıca, oluşturmaya çalıştığı Şii Hilâli'ni ${ }^{5}$ korumak adına Esed rejiminin gücünü muhafaza etmesini istiyordu. İran'a göre Esed'in koltukta kalmas1, Irak, Lübnan hatta Mısır ile olan ilişkilerini geliştirecek, İsrail'e karşı güvenliğini de arttıracak faktörlerin başında gelmekte idi. Bu yüzden İran'ın Esed rejimine olan desteğini sadece tarihi, kültürel ve mezhepsel sebeplere dayandırarak açılamaya çalışmak yeterli olmayacaktır. İran'ı Suriye'ye çeken bu sayılanlara ek olarak realpolitik ve stratejik gerçeklerdir. Devrim Muhafizları komuta kademesi ve İran yönetimine göre Suriye İran'ın terörizmle ve DAEŞ gibi tekfiri gruplarla olan mücadelesindeki ilk savunma hattıdır. ${ }^{6}$ Bu yüzden de ayakta kalması gerekmektedir. Bu sayılanlara ek olarak İran'ın Şii Hilali olarak da adlandırılan Ortadoğu'ya yönelik yüksek stratejisi Suriye'de Sünni bir idarenin başa geçmesi halinde sekteye uğrayacak ${ }^{7}$ ve İran'ın bölgeye yönelik güç projeksiyonu yapma

4 Fulton - Holliday - Wyer, a.g.e., s. 10.

5 "Şii Hilali tabirini ilk kez kullanan kişi Ürdün Kralı II. Abdullah olmuştur. Ortadoğu'daki Sünni devletleri kuşatma amacı taşıyan bu stratejinin coğrafi sinırlarını Kral II. Abdullah şu şekilde tarif etmişti: Hilal İran'dan başlamakta, Şii nüfusunun çoğunlukta olduğu Irak' da içine alarak Alevi elitlerin yönettiği Suriye'den, Şii nüfusun git gide artmakta olduğu Lübnan'a kadar genişlemektedir.” İrem Bilgetürk, “İranın Suriye Politikası Bağlamında Şiilik ve Şii Milisler”, Ankasam, Bölgesel Araştırmalar Dergisi, cilt 2, sayı 2, Aralık 2018, s. 402. Ayrıca bkz. Emin Salihi, “Ortadoğu'da Oluşan Yeni Dengeler ve 'Şii Hilali' Söylemi””, Bilge Strateji, cilt 2, sayı 4, Bahar 2011, s. 183-202; Tunahan Hazır, "Şii Hilali Bağlamında Suriye İç Savaşı ve İran", TURAN-SAM, Turan Stratejik Araştırmalar Merkezi, cilt 11, sayı 43, Yaz 2019, s. 359-365. Daha fazla bilgi için bkz. Müjde Aysun Özbay, “İran'ın Şii Hilal Projesi İddiası”, (Yayımlanmamış Yüksek Lisans Tezi), Ankara Üniversitesi, Sosyal Bilimler Enstitüsü, Ankara, 2010. Ayrıca bkz. Utku Başar, “Şii Hilali' Gerçek Oldu!”, CNN Türk, 10.03.2015, https://www.cnnturk.com/yazarlar/guncel/utku-basar/sii-hilali-gercek-oldu , Erişim tarihi 02.08.2020.

6 Ansari - Tabrizi, a.g.e., s. 3.

7 Bkz. Bryan Pierce, "Syria: A Wicked Problem for All”, CTC Sentinel, (Özel Say1), cilt 6, say1 8, Ağustos 2013, s. 2. Ayrıca bkz. Karim Sadjadpour, "Iran's Unwavering Support to Assad's Syria”, CTC Sentinel, (Özel Sayı), cilt 6, say1 8, Ağustos 2013, s. 11-14. 
imkanı da azalacaktır. ${ }^{8}$ Bu kötü gidişatın önüne geçebilmek için İran, Suriye İç Savaşı'na dahil olmak zorunda kalmıştır.

Bu noktada Suriye İç Savaşı'nın neden ve nasıl başladığını kısaca hatırlamak yerinde olacaktır: Babası Hafız Esed'in ölümünden sonra Beşşar Esed iktidara geldiğinde Soğuk Savaş sonrası dönemin değişen paradigmalarına uyabilmek ve Batı Dünyası ile yakınlaşabilmek adına bir dizi neo-liberal reform yapma yoluna gitmişti. Ancak bu reformları refah politikalarıyla desteklemeyi ihmal etmiştir. $\mathrm{Bu}$ ise Soğuk Savaş sonrası dönemde Sovyetler Birliği'nin mali desteğini kaybeden ülkede fakirliğin, işsizliğin ve gelir dağılımı dengesizliğinin artmasına sebep olmuştur. Mali yapının bozulması sonucunda ortaya çıan ekonomik krizin 2011 yılında Esed rejimine karşı başlayan ayaklanmaların en büyük sebeplerinden biri olduğu bilinmektedir. Ancak ekonomik faktörler isyanın tek sebebi değildir, siyasi sebepler de bu duruma katkıda bulunmuştur. Suriye'nin komşusu Lübnan'da 2005 y1lında gerçekleşen Sedir Devrimi'nden sonra Lübnan'da bulunan Suriye askeri gücü ülkeden ayrılmak zorunda kalmıştı. Bu durum Suriye halkı tarafından bir yenilgi olarak görülmüş ve 2007 yılında yapılan seçimleri kazanmasına karşın Esed'in politik gücünde gözle görülür bir düşüşe sebep olmuştu. ${ }^{9}$ Kötüye giden durumu fark eden Beşşar Esed muhalefete bazı tavizler verme yoluna gitmişti. Bu tavizler arasında Müslüman Kardeşler'in politik aktiviteler yürütmesine izin verilmesi de vard. Ancak taviz verirken bir yandan da babası Hafız Esed'in yaptığ 1 gibi, otoriter uygulamaları da sürdürme yoluna gitmiştir. Bu durum sonucunda ortaya çıkan siyasal katılımın azlığ 1 ve alınan çeşitli politik önlemler rejimin otoriterleşmesine sebep olmuştur. ${ }^{10}$ Güvenlik güçleri insanları keyfi olarak tutuklamaya başlamış, özellikle İslamcı ve Kürt muhalif gruplar baskı altına alınmıştır. Ekonomik liberalleşme için atılan her adım ülkedeki mevcut elitin işine yaramış, halka yeni firsatlar sunmamıştır. ${ }^{11}$ Ayrıca, Deraa'da siyasi duvar yazıları yazan çocukların tutuklanması sonrasında siyasi suçluların serbest bırakılmasını talep eden gösteriler sırasında güvenlik güçlerinin halka karşı olan sert tutumu ülke genelinde çeşitli gösterilerin ortaya çıkmasına sebep olmuştur. Artan gerginliğin azaltılması için pek çok siyasi suçlu serbest bırakılmış, hükümet feshedilmiş ve

8 Fulton - Holliday - Wyer, a.g.e., s. 9.

9 Çağatay Özdemir, "Suriye'de İç Savaşın Nedenleri: Otokratik Yönetim mi, Bölgesel ve Küresel Güçler mi?”, Bilgi Sosyal Bilimler Dergisi, sayı 2, 2016, s. 89.

10 William R. Polk, "Understanding Syria: From Pre-Civil War to Post-Assad", The Atlantic, 10.03.2013, https:/www.theatlantic.com/international/archive/2013/12/understanding-syriafrom-pre-civil-war-to-post-assad/281989/ , Erişim Tarihi 22.10.2020.

11 "Syrian President Bashar Al-Assad: Facing Down Rebellion”, BBC News, 31.08.2015, https:// www.bbc.com/news/10338256, Erişim Tarihi 22.10.2020. 
ülkede 48 yıldır süren olağanüstü hâle son verilmiştir. ${ }^{12}$ Ancak muhalefetin talepleri devam etmiş, gösteriler ve onlara yapılan müdahalaler bir süre sonra taraflar arasında silahlı çatışmalara dönüşmüştür. Bu açıdan 2011 yılında başlayan Suriye Devrimi ve sonrasındaki iç savaş özellikle mevcut rejim açısından tam bir sürpriz olmuştur.

Bilindiği gibi savaşın başlangıç döneminde Suriye rejimine muhalif gruplar karşısında hızla geri çekilen Esed güçleri, ülke içinde birçok bölgenin kontrolünü kaybetmişti. ${ }^{13}$ İç savaşın ilk günlerinde Suriye'deki varlı̆̆ının dikkat çekmesini istemeyen İran bu dönemde Suriye rejimine olan desteğini sınırlı tutmuş, daha çok teknik ve finansal destek sağlamaya odaklanmıştı. Rejime sağlanan sınırlı yardım Devrim Muhafizları'na bağlı Kudüs Gücü vasıtasıyla ulaştırılıyordu. ${ }^{14}$ Ancak bu desteğin yeterli olmadığını gören İran 2012 yılı sonlarında paramiliter bir güç olan Milli Savunma Güçleri'nin (National Defense Forces/ Kuvvet ed-Difa el-Vatani) kurulmasına destek verdi. ${ }^{15}$ Ancak, Suriye ordusunun tek baş1na muhaliflerle başa çıkamayacağının anlaşılması üzerine İran ülkeye yabancı ülkelerden gelen Şii milisleri getirmeye başladı. Bu kapsamda 2012 yılında ilk olarak Hizbullah milisleri getirildi. ${ }^{16}$ Eş zamanlı olarak Iraklı Kata'ib el-İmam Ali gibi yabancı kökenli milis gruplarına verilen silah ve eğitim desteğinde artışa gidildi. ${ }^{17}$ Bunlara ek olarak Afgan ve Pakistanlı Şii gönüllülerden Fatımiyyun ve Zeynebiyyun Tugayları oluşturuldu ve Suriye'de savaşa gönderildi. ${ }^{18}$ Para-

12 Özdemir, a.g.m., s. 90.

13 "Esed Rejimi 2012 yazında ülkenin kuzeyi ve doğusundaki kontrolünü kaybetmeye başlamıştı." Fulton - Holliday - Wyer, a.g.e., s. 9.

14 Benzer görüş için bkz. Fulton - Holliday - Wyer, a.g.e., s. 9.

“Kudüs Gücü Iran'ın ülke dışındaki gizli askeri operasyonlarından sorumludur.” Fulton - Holliday - Wyer, a.g.e., s. 10.

15 "Milli Savunma Güçleri farklı mezhepler ve gruplardan gelen 100.000 kadar gönüllü savaşçıdan oluşuyordu. Iran bu gruba aleni olarak mali destek sağllyordu." Ansari - Tabrizi, a.g.e., s. 4.

"Milli Savunma Güçleri'nin kurucusu ve fikir babası Kasım Süleymani idi. Süleymani bu paramiliter grubu Iran'ın Besic Milislerini örnek alarak oluşturmuştu. Milli Savunma Güçleri militanları Suriye, Lübnan ve Iran'daki tesislerde Iran Devrim Muhafizlart ve Hizbullah gerillalarından meskun mahalde çatışma ve gerilla eğitimi alıyorlardı. Iran bu yapı altında farklı grupları birleştirmiş, onları eğitmiş ve silahlandırmıştı." Daha fazla bilgi için bkz. Fulton Holliday - Wyer, a.g.e.

16 Ansari - Tabrizi, a.g.e., s. 5.

17 Omar Al-Jaffal, ‘Iraqi Shiites Join Syria War', Al-Monitor, 29 Ekim 2013.

18 Bunların hepsi İran Devrim Muhafızları Ordusu komutanı General Muhammed Ali Caferi'nin emrinde idiler. Daha fazla bilgi için bkz. Hashmatallah Moslih, "Iran 'Foreign Legion' Leans on Afghan Shia in Syria War”, Al Jazeera, 22 Ocak 2016, https://www.aljazeera.com/ news/2016/01/iran-foreign-legion-leans-afghan-shia-syria-war-160122130355206.html, Erişim tarihi 06.08.2020. 
militer güçler Suriye rejimi ve İran için daha önemli hale gelmeye başladı çünkü çatışmanın doğası gösteriler ve ayaklanmadan hızla iç savaşa doğru evrilmeye başlamıştı. ${ }^{19}$

İşte bu noktada İran tarafindan koordine edilen Şii milislerin Suriye İç Savaşı'na katılmasıyla savaşın gidişatı değişmeye başladı. ${ }^{20}$ Şii nüfusunun yoğun olduğu ülkelerden gelen paralı ve gönüllü savaşçılardan oluşan bu milis güçleri İran Devrim Muhafızları'na ${ }^{21}$ bağlı Kudüs Gücü² tarafından

19 Fulton - Holliday - Wyer, a.g.e., s. 9.

20 “Suriye'de İ̧ Savaş’ın başlamasından itibaren ülkedeki tüm gelişmelerle yakından ilgilenen Tahran yönetimi, stratejik ortak olarak nitelendirdiği Esed rejimini her koşulda savunma kararı almıştır. Bu açıdan, ABD, Türkiye ve Körfez ülkeleri tarafindan desteklenen muhaliflerin hızla ilerleme kaydetmesi üzerine kaygılanan Tahran yönetimi, Esed rejimine yönelik desteğini artırmıştır." Rahimullah Farzam - İsmail Sarı, "Fatimiyyun: İran'ın Afgan Milisleri”, Selçuk Üniversitesi, Selçuklu Araştırmaları Dergisi, sayı 6, 2017, s. 277. Ayrıca bkz. Jubin Goodarzi, Iran and Syria, The Iran Primer, United States Institute of Peace, 2010, https://iranprimer.usip. org/resource/iran-and-syria, Erişim tarihi 28.05.2020

21 “Yasal dayană̆ını İran Anayasası'nın 150. Maddesinden alan Devrim Muhafizları doğrudan Iran İslam Cumhuriyeti'nin dini lideri Ali Hamaney'e bağlı olup, Milli Savunma Yüksek Şurası bünyesinde bă̆ımsız bir ordu şeklinde örgütlenmiştir. Asıl görevi İran Devrimi'nin koruyuculuğunu yapmak olan Devrim Muhafizlarl, ülkede imar faaliyetlerinden (baraj inşası, yol ve kanalizasyon yapımı, taşımacılık, maden işletmeciliği, zirai faaliyetler, danışmanlık hizmeti vs.) kültürel faaliyetlere, eğitimden doğal afetlerle mücadeleye kadar birçok alanda faaliyet göstermektedir. Çok iyi eğitilmiş ve oldukça organize bir örgüt olan Devrim Muhafizlarl; 15 bini Hava Kuvvetlerinde, 20 bini Deniz Kuvvetlerinde ve 230 bini ise Kara Kuvvetlerinde olmak üzere toplam 265 bin personele sahiptir.” Farzam - Sarı, a.g.m., s. 273.

"Iran Íslam Cumhuriyeti Anayasası, Madde 150: Devrim zaferinin ilk günlerinde oluşturulan İslam Devrimi'ni koruma ordusu, Devrimi ve Devrim hareketlerinin devamlılı̆̆ını sağlamak amacıyla kurulmuştur. Bu ordunun faaliyet ve sorumluluk alanı, diğer silahlı kuvvetlerin sorumluluk alanıyla bağlantılı olarak aralarında koordineli ve kardeşçe bir işbirliğine dayanmasl, yasa ile belirtilecektir.” Farzam - Sar1, a.g.m., s. 273.

22 "Yaklaşık 15-20 bin askeri personeli bulunduğu tahmin edilen Kudüs Gücü ise Devrim Muhafizları'nın bir alt birimi olup, yurt dışındaki askeri faaliyetleri yürütmekten sorumludur. Bu özel birimde görev yapanlar doğrudan çatışmaya girmek, suikastlar düzenlemek ve istihbarat toplamak üzere Tahran ve Şiraz'da eğitilmektedir. Askeri eğitim tamamlandiktan sonra üyelerin büyük bir kısmı dini merkez olan Kum şehrinde ayrıca dini bir eğitimden geçirilmektedir. Kudüs Gücü'nün dokuz farkl ülke ve bölgeden sorumlu olan dokuz birimi bulunmaktadır: 1 . birim Irak, 2. birim Pakistan, 3. birim Türkiye, 4. birim Afganistan, 5. birim Türki cumhuriyetler, 6. birim Körfez ülkeleri, 7. birim Suriye ve Lübnan, 8. birim Kuzey Afrika ülkeleri, 9. birim Avrupa ve Amerika kıtası ülkelerinden sorumludur. Devrim Muhafizları'nın kara, hava, deniz ve Besic ile birlikte 5 biriminden biri olan Kudüs Gücü, ilk kez Iran-Irak Savaşı sırasında Irak'taki Saddam muhaliflerini örgütleme görevini üstlenirken, daha sonra Afganistan ve Lübnan Savaşlarında gerçekleştirdiği faaliyetlerle adından söz ettirmiştir.” Farzam - Sarı, a.g.m., 
örgütlenmektedir. Bilindiği gibi İran'ın, Devrim Muhafızları aracılığıyla kendi çıkarları doğrultusunda kullanmak üzere yabancı savaşçıları örgütlemesi hiç de yeni bir olay değildir. ${ }^{23}$

İran, Ortadoğu'da kendi çıkarları doğrultusunda hareket edecek milis gücü oluşturma konusunda tecrübe sahibi bir ülkedir. Günümüzde Suriye'de yabanc1 Şii savaşçıların çoğunluğunu Irak ve Lübnanlılar oluşturmakla birlikte dünyanın birçok bölge ve ülkesinden Suriye'de rejim saflarında savaşmak üzere gelen gönüllü Şii milisler mevcuttur. Arap olmayanlar arasından en büyük katılımı Şii Afganlar oluşturmakta ${ }^{24}$ ve Suriye'de Fatımiyyun Tugayı bünyesinde görev almaktadırlar. ${ }^{25} 1980$ 'li yılların başında Humeyni'nin söylemlerinden etkilenen Afganlar tarafindan kurulan bu birlik İran-Irak Savaşı ve Afgan İç Savaşı'na katılmıştır. Suriye İç Savaşı'nda da İran Devrim Muhafızları'na bağlı bir grup olarak görev yapmaktadır. İddialara göre grubun zayiatı oldukça fazladır. ${ }^{26}$ Genellikle de en tehlikeli bölgelere gönderilmektedir.

Genel olarak İran'da yaşayan Afgan Hazara topluluğu içinden seçilen veya gönüllülerden oluşan Fatımiyyun Tugayının kuruluş amacı olarak Şam yakınlarında yer alan Seyyide Zeynep Türbesi'nin iç savaştan korunması gösterilmektedir. İran'ın kendi askeri gücü ve İran destekli milislerin mevcudiyeti Suriye İç Savaşı süresince düzenli olarak artmıştır. İran'daki Şii Afgan mültecilere Suriye İç Savaşı'na gönderilen İran destekli milis gücüne katılırlarsa iyi bir ücret alacakları, bu sayede ailelerine para gönderebilecekleri, İran'da ikamet izni ve İran toplumu içinde saygın bir sosyal statüye sahip olacakları vaat edilmektedir.

s. 274. Ayrıca bkz. Bekir Ünal, “İran’ın Vekâlet Savaşı Stratejisi ve Suriye'deki Şii Milisler”, Bilgesam Analiz, no 1304, 2015, s. 2.

23 Farzam - Sar1, a.g.m., s. 270.

24 “... Pakistanlı Şiiler, Hindistan’daki Şiiler, Somali ve Fildişi Sahili gibi Afrika ülkelerinde yaşayan Şii nüfus içinden gönüllüler de Suriye'de savaşmaktadır. Suriye'deki Şii milisler arasında ABD ve Kanada vatandaşı olan Arap kökenli Şiiler de vardır.” Farzam - Sarı, a.g.m., s. 271.

25 Farzam - Sar1, a.g.m., s. 272.

“Fatimiyyun Tugayı, Iran'ın kendi vekâlet savaşı stratejisi doğrultusunda Suriye rejimi saflarında savaşması için örgütlediği milis gruplardan biri olup, özellikle Afgan Şii Hazaralardan oluşmaktadır." Farzam - Sarı, a.g.m., s. 278.

26 Christoph Reuter, "Murad's War: An Afghan Face to the Syrian Conflict", Afghanistan Analysts Network, 26 Haziran 2015, https:/www.afghanistan-analysts.org/murads-war-an-afghan-face-to-the-syrian-conflict/, Erişim tarihi 24 Ocak 2020. Ayrıca bkz. Golnaz Esfandiari, "Increasing Number Of Afghans, Pakistanis Killed In Syria Buried In Iran", Radio Free Europe, Radio Liberty, 25 Nisan 2015, https://www.rferl.org/a/persian-letters-afghans-pakistanis-killed-fighting-in-syria-for-iran/26977907.html, Erişim tarihi 24 Ocak 2020. 
İşte bu çalışmada Fatımiyyun Tugayı'nın ortaya çıkışı ve büyümesi, en son olarak da Suriye İç Savaşı'ndaki faaliyetleri incelenecektir. Keza bu dahlin İran'da yaşayan Afgan Hazara topluluğuna ve Afganistan'a olan etkilerine de değinilmeye çalışılacaktır. Bu çalışma ile amaçlanan ve alana yapılması beklenen katkı ise Afganistan'da yaşayan ama haklarında pek fazla bilgi bulunmayan Hazaralara dikkat çekmektir. Tarihleri ve kültürleri incelendiğinde Türkiye Türkleri ile bazı ortak noktaları olduğu görülen Hazaraların incelenmesi Türkiye Tarihi’nin inanç ve etnisite gibi ihtilaflar barındıran konularının açıklığa kavuşturulmasında faydalı olabilecektir. Bu duruma ek olarak İran tarafından suiistimal edildikleri görülen bu grup üzerinden İran'ın vekâlet savaşlarında uyguladığı stratejiler ve kullandığı yöntemlere de dikkat çekilmesi amaçlanmaktadır. Bu amaçla makalenin yazımı aşamasında birincil ve ikincil kaynaklara başvurulmuş ve bu kaynaklar bir arada kullanılmıştır. İran'ın Afganistan'ın dışlanmış gruplarından birisi olan Hazaralardan faydalanmak için geliştirdiği yöntemlerin incelendiği bu çalışmada, öncelikle Hazaraların kim olduğu sorusuna odaklanılmış, bu konudaki görüşlere değinilmiştir. Kimlikleri ve tarihleri hakkında arka plan oluşturulduktan sonra Fatımiyyun Tugayı ve Hazaraların Suriye İç Savaşı'na nasıl müdahil oldukları, onları bu çatışmaya katılmaya iten motivasyon sebeplerine değinilmiştir.

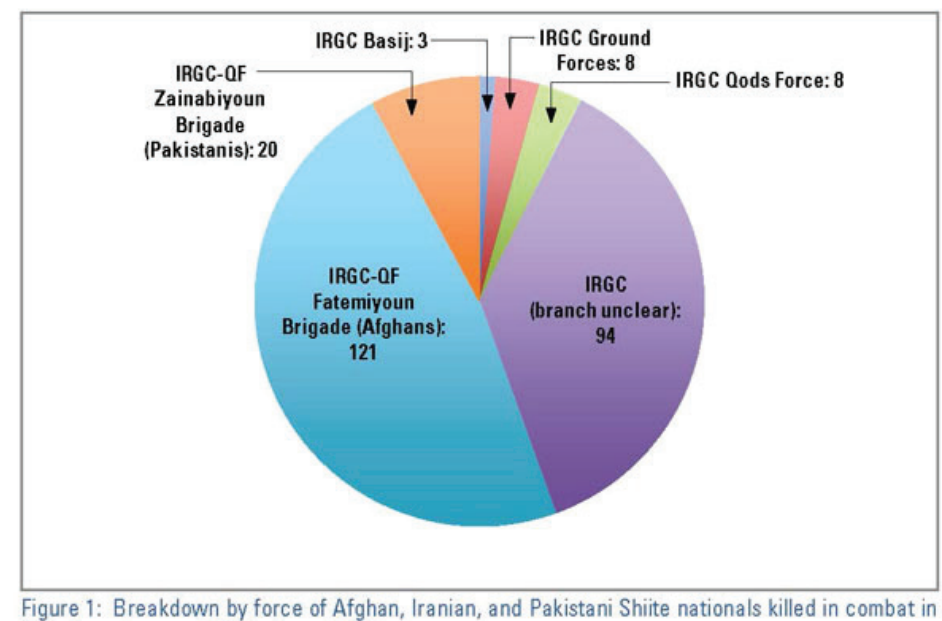
Syria from January 2013 to August 2015.

Resim 1. Şii Milis Kayıpları (2013 Ocak-2015 Ağustos Dönemi). Kaynak: Ali Alfoneh, Shiite Combat Casualties Show the Depth of Iran's Involvement in Syria, Policy Watch 2458, 3 Ağustos 2015, The Washington Institute, (https://www.washingtoninstitute. org/policy-analysis/view/shiite-combat-casualties-show-the-depth-of-irans-involvement-in-syria), (Erişim Tarihi: 03.05.2020). 


\section{Hazaralar ve Afganistan: Hazaralar'ın Tarihi}

Kabile/aşiret yapısını önceleyen Afganistan'ın toplumsal ve sosyal iç dinamikleri, güçlü bir merkezi devlet ve ulusun ortaya çıkmasına engel olmuştur. $\mathrm{Bu}$ yüzden devlet bürokrasisi ve kurumları tam olarak gelişememiştir. 20. yüzyılın ilk yarısına kadar olan dönemde Afganistan'ı modernleştirme çabaları, komşu ülkelerde ve Avrupa' da gerçekleşen Modernizm sürecinin etkisi altında başlamıştır. Bu kapsamda Afgan Emiri Şir Ali Han, İngiltere'nin daveti sonrasında Hindistan'daki İngiliz idaresinin uygulamalarını yerinde görmek amacıyla bir geziye çıkmış, o dönemdeki tüm yabancı devlet adamları gibi gördüklerinden çok etkilenmiştir. Afganistan'a geri döndükten sonra bazı düzenlemeleri ülkesinde de hayata geçirmeye karar vermiştir. ${ }^{27}$

Emir Şir Ali Han 1879 yılında tahttan indirilmesinden sonra yerine Muhammed Yakup Han (1879-1879) geçmiş, onu takiben Abdurrahman Han (18801901), Habibullah Han (1901-1919) ve Nasrullah Han (1919-1919) Afgan Kralı olmuştur. Nasrullah Han'1 da aynı yıl tahta çıkan Emanullah Han izlemiştir. Afgan Kralı olan Emanullah Han da 1927 yılında Avrupa'ya yaptığı ziyaretten sonra, modernleşme ve yenileşme konusuna daha ciddi bir şekilde eğilmeye başlamıştır. Bu modernleşme çabası sırasında ise önce Osmanlı İmparatorluğ ${ }^{28}$ ve daha sonra Cumhuriyet dönemi Türkiye'sini ${ }^{29}$ örnek alma ve onun tecrübe ve bilgi birikiminden yararlanmayı en uygun çözüm olarak görmüştür. Bu kapsamda Türkiye'den uzmanlar getirilmiş ve Türkiye' deki ıslahatların benzerlerini Afganistan' da hayata geçirmeye çalışmıştı. ${ }^{30}$

27 Afgan Emiri Şir Ali Han'ın modernleşme çabaları ve Hindistan ziyareti hakkında bkz. Abdül Metin Çelikbilek, “Afganistan Emiri Şir Ali Han'ın Modernleşme Çabaları”, Bartın Üniversitesi Çeşm-i Cihan: Tarih, Kültür ve Sanat Araştırmaları E-Dergisi, cilt 4, sayı 2, Kış 2017, s. 94-110.

28 "Afgan-Türk ilişkileri tarihine bakıldı̆̆ında karşımıza ilk çıkan isimlerden biri Cemal Paşa'dır. I. Dünya Savaşı sonrası Cemal Paşa, Afganistan'ın Türkiye'den sonra, İslam âleminin en kuvvetli ikinci devleti olmasını istemiştir. Bunun gerçekleşmesi içinde, Afganistan'ın modernleşmesi gerektiğine inanmıştır. Modernleşmeyi ordudan başlatmak isteyen Cemal Paşa, I. Dünya Savaşı 'nda Ruslar'a esir düşmüss subaylardan bir kısmını serbest bıraktırıp yanına alarak, Afganistan'da modern bir alay kurmuştur. Müteakiben, kuvvetli bir Afgan ordusu kurmak için maddi destek almak amacıyla, Rusya ve Almanya'ya gitmiştir. Burada, Avrupa devletleri tarafindan Afganistan'in tanınması amacıyla, Avrupa'ya gönderilen Muhammed Veli Han Başkanlığındaki Afgan heyetiyle Berlin'de buluşarak, önce Alman hükümet temsilcileri ve sonrasinda da Fransa'ya beraber giderek, Fransiz hükümet temsilcileri ile Afgan temsil heyetini tanıştırmış ve bu iki devletin Afganistan’ı resmen tanımasını sağlamıştır.” Bkz. Mehmet Saray, Dünden Bugüne Afganistan, İstanbul, Boğaziçi Yayınları, 1981, s. 142-144 ve 145.

29 Ehsanullah Farzan, “Afgan Modernleşme Çabalarında Türkçe'nin Etkisi”, International Journal of Teaching Turkish as a Foreign Language, cilt 2, say1 2, 2019, s. 192.

30 Farzan, a.g.e., s.193. 
$\mathrm{Bu}$ dönemde Türk-Afgan ilişkilerinin gelişmesinde Atatürk ve Emanullah Han'ın tesis ettiği ikili ilişkinin etkisi vardır. ${ }^{31}$ Türkiye Afganistan'ı her zaman kardeş ülke olarak görmüş ve her konuda yardım etmeye çalışmıştır. Bu iyi ilişkiler sonucunda Emanullah Han da modernleşme konusunda Atatürk'ü örnek almıştır. ${ }^{32}$ Öyle ki, Emanullah Han, ikili görüşmelerinde Atatürk'e "Ağabeyim" diye hitap etmiş ve yapacağı uygulamalarla ilgili olarak onun tavsiye ve görüşlerini alma yoluna gitmiştir. $\mathrm{O}$ dönemde Atatürk'ün Emanullah Han'a en önemli tavsiyesi, öncelikle güçlü bir ordu kurması ve ondan sonra diğer modernleşme girişimlerini başlatması olmuştur. ${ }^{33}$ Ancak Emanullah Han, yakınlarının güçlü bir ordunun kendisini devirebileceği telkinlerinin etkisinde kalarak, ordunun modernizasyonunu ağırdan almıştır. ${ }^{34}$ Atatürk'ün ordunun güçlendirilmesi konusundaki tavsiyelerine rağmen Emanullah Han bu konudaki önerilerini dikkate almamış, kanun ve otoriteyi ülkede iyice yerleştirmeden ve ordusunu güçlendirmeden, reform sürecini başlatmıştır. Bunun sonucunda ise yapılan bir darbe sonucunda devrilmiştir.

Emanullah Han'in devrilmesinden sonra bir çete lideri olan Habibullah, Kabil'de Emirliğini ilan etmiş ve ülkeyi kaos ortamına sürüklemiştir. Bunun üzerine Fransa'dan gelen Nadir Han ve kardeşleri, 1929 yılında Habibullah'1 yenerek, Afganistan'da düzeni yeniden tesis etmişlerdir. Düzenin tesisinden sonra yeni Kral'ı belirlemek için, 16 Ekim 1929'da Kabil'de, kabile ve aşiret reisleri, Türk, İran ve Rus Büyükelçilerinin de katıldığı bir toplantı düzenlenmiştir. Toplantıya katılanların büyük çoğunluğu Nadir Han'ın tahta geçmesini istemiştir. Bu isteği kabul eden Nadir Han da ülkenin yeni Kral'1 olarak tahta çıkmıştır. ${ }^{35}$

Nadir Şah, ilk iş olarak, 31 Ekim 1931'de, 1964'e kadar küçük değişiklerle yürürlükte kalacak olan Anayasa'yı kabul etmiştir. İlköğretime, ordunun modernleşmesine, ulaşım altyapısının geliştirilmesine ve rüşvet ve yolsuzlukla mücadeleye büyük önem vermiştir. Nadir Şah tarafından yapılan Müslüman halkın hayatında büyük sarsıntılar yaratmayan, mütevazı ve gerçekçi yenilikler ülkenin

31 Türk-Afgan İlişkileri hakkında daha fazla bilgi için bkz. Hüsnü Özlü, “"Türk-Afgan Dostluk ve İşbirliği Antlaşması' Kapsamında Atatürk Dönemi Türkiye-Afganistan İlişkilerine Bakış”, Uluslararası Avrasya Sosyal Bilimler Dergisi, y1l 3, sayı 8, Eylül 2012, s. 31-46.

32 Lucy Morgan Edwards, "State-building in Afghanistan: A Case Showing the Limits?", International Review of the Red Cross, cilt 92, say1 880, Aral1k 2010, s. 973.

33 Saray, Dünden Bugüne Afganistan ..., s. 151.

34 Saray, Dünden Bugüne Afganistan ..., s. 153-155.

35 Saray, Dünden Bugüne Afganistan ..., s. 157-159. 
ilerlemesine destek olmuş ve modernleşme sürecine katkı sağlamıştır. ${ }^{36}$ Nadir Şah 1933 yılında öldürülünce, yerine oğlu Zahir Şah geçmiştir. Yaşı küçük olduğundan ülke Nadir Şah'ın kardeşleri (Meşhur Beş Kardeşler) tarafından 1953'e kadar vekaleten yönetilmiştir. Bu dönemde Afganistan Emanullah Han'dan itibaren takip ettiği tarafsızlık politikasını terk etmiş, bunun sonucunda ülke uluslararası arenada giderek yalnızlaşmaya başlamıştır. Uluslararası siyasette ortaya çıkan yeni konjonktürde Afganistan'ın dünyanın geri kalan kısmından izole olup, içine kapanmasını önlemek için Türkiye girişimlerde bulunmuştur. Bu kapsamda öncelikle İran-Afganistan sınır sorunu konusunda hakemlik yapılmış, daha sonra da Afganistan'ın Miletler Cemiyetine girmesine destek verilmiştir. Bu destek sonucunda Afganistan dış politikada düştüğü sıkıntılardan kurtulmayı başarmıştır. Yine bu girişimler kapsamında, II. Dünya Savaşı öncesinde, Türkiye'nin Afganistan Büyükelçisi Memduh Şevket Esendal'ın çabalarıyla, Afganistan'ın İtalyan ve Alman nüfuz ve etki alanına girmesi engellenmiş ve İran'la birlikte Sadabat Paktı'na girmesi sağlanmıştır. II. Dünya Savaşı sırasında ise Afganistan, tıpkı Türkiye gibi, tarafsız bir politika izleme yoluna gitmiştir.

II. Dünya Savaşı'nın sona ermesini takiben Afganistan'da bazı siyasi değişiklikler meydana gelmiştir. Bu değişikliklerden en önemlisi, Başbakan Haşim Han'ın 1946'da görevinden çekilmesi ve yerine Şah Mahmud'un getirilmesidir. Mahmud Han ülkede barışı ve istikrarı sağlamış, bu sayede ülkenin sınırlı ve mütevazı gelişmesi devam edebilmiştir. Bu dönemde Türkiye Afganistan'a askeri konularda ve eğitim faaliyetlerinin geliştirilip, sürdürülmesi konusunda yardım yapıp ülkenin gelişmesine destek olmaya devam etmiş̧tir. Yine II. Dünya Savaşı'ndan sonra Pakistan'la Durand Hattı'ndan kaynaklanan Afganistan-Pakistan sınırın belirlenmesi ve Peştun sorunu konusu yeniden gündeme gelmiştir. ${ }^{37} \mathrm{ABD}$, bu dönemde sorunun çözümü için iki taraf arasındaki arabuluculuk yapmayı teklif etmiş ancak bu teklif Pakistan tarafından kabul görmemiştir. Bunun üzerine ABD, her iki tarafin da güvenebileceği bir ülke olan Türkiye'nin arabuluculuğunu taraflara önermiştir. Bu teklif Afganistan tarafından kabul görse de Pakistan tarafın-

36 Saray, Dünden Bugüne Afganistan ..., s. 159-163.

37 “Afganistan, Pakistan'la yüzyıllardır süre gelen bir sınır sorunu vardır. Durand (The Durand Line) Hattı adı verilen Afganistan-Pakistan sınırı tam olarak nereden geçtiği belli değildir. Afganlar farklı yerlerden ve Pakistanlılar farklı yerlerden geçtiğini savunmaktadırlar ki zaman zaman sınır çatışmalarını da beraberinde getirmektedir.” Esmatullah Surosh, “Afganistan'ın Etnik Grupları Arasındaki Çatışmaların Temel Nedenlerinin Analizi”, 14/01/2018, Kafkasya Stratejik Araştırmalar Merkezi-Kafkassam, https://kafkassam.com/afganistanin-etnik-gruplar-arasindaki-catismalarin-temel-nedenlerinin-analiz.html , Erişim tarihi 12.05.2020. 
dan reddedilmiştir. ${ }^{38}$ Yine bu dönemde Afganistan, Sadabat Paktı'na alınmasına rağmen, Bağdat Paktı'ndan dışlanmıştır. ${ }^{39}$ Yine de Türkiye, Sovyet İşgali’ne kadar Afganistan'a talep edilen her konuda yardımcı olmaya devam etmiştir.

Ancak 1979 yılında Sovyetler Birliği’nin Afganistan'1 işgal etmesi ile başlayan süreç Afganistan'ın ülke yönetimindeki bütünlügünün kaybolmasına neden olmuştur. Ülkedeki en son nüfus sayımı 1979 yılında yapılmış olduğu için Afganistan'ın etnik yapısı konusunda sağlıklı bir veriye ulaşmak oldukça zor olabilmektedir. ${ }^{40} \mathrm{Bu}$ da toplumsal yapılarla ilgili bilgi toplamayı güçleştirmektedir. Bundan dolayı yapılan çalışmalarda ülkedeki etnik yapı ile ilgili birbirinden farklı sonuçlar ortaya çıkmakta ve farklı etnik gruplar kendilerini siyasi denklemde avantajlı konuma getirecek bir veri ortaya koyma adına zaman zaman bu rakamları manipule etmeye dahi çalışmaktadır. Ülkenin etnik kompozisyonu tespit etme adına yapılan çalışmalarda Afganistan'da, çalışmanın konusu olan Hazaralar'ın \% 20'lik bir oranla ülkedeki en büyük azınlık grubu oluşturduğu ve 6 milyonu aşkın bir nüfusa sahip olduğu iddia edilmektedir. ${ }^{41} \mathrm{Bu}$ iddiayı destekleyen resmi veri ise 1991 yılında Birleşmiş Milletler'in desteğiyle yapılan nüfus sayımıdır. Bu sayım sonrasında ortaya çıkan sonuca göre Afganistan'da 6.5 milyon Hazara yaşamakta idi. ${ }^{42}$

38 Saray, Dünden Bugüne Afganistan, s. 165-173.

39 “Dönemin Cumhurbaşkanı Celal Bayar'ın ifadesiyle Afganistan, Bă̆dat Paktı'na ABD Başkanı Eisenhower'ın istememesinden dolayı alınmamış ve Türkiye'nin tüm çabalarına rağmen yalnızlaştırılmaya çalışılmıştır." Mehmet Saray, "Afganistan Üzerine Bir Söyleşi”, Afganistan Üzerine Araştırmalar, der. Ali Ahmetbeyoğlu, içinde (177-192), İstanbul, Tarih ve Tabiat Vakfı (TATAV) Yayınları, 2002, s. 185.

40 “Afganistan'da 1979 yılından bu yana nüfus sayımı yapılmamıştır." Afganistan Ülke Raporu, Kabil, T.C. Kabil Büyükelçiliği, Ticaret Müşavirliği, 2017, s. 2.

"Ülkede ilk nüfus sayımının 1979 yılında yapıldığını, bu ilk sayımdan sonra Afganistan'ın nüfusunun 15.5 milyon olarak açılandı̆̆ını ifade edilmektedir." "Afganistan'da 23 Yıl Sonra Nüfus Sayımı”, Hürriyet, 01 Eylül 2002, https://www.hurriyet.com.tr/dunya/afganistanda-23-yil-sonra-nufus-sayimi-94899, Erişim tarihi 08.05.2020.

41 Mehmet Toplu, "Hazara Türklerinin Geçmişi ve Bugünü”, Azarbaycanlıların və Digər Türkdilli Xalqların Әməkdaşlıq Mərkəzi, (ATXӘM), 19 Ekim 2016, http://atxem.az/news/a-15486. html, Erişim tarihi 25.02.2020.

Ayrıca bkz. Jacques Neriah, "Iran Deploys Afghan Shiite Brigade to Spread Its Control in Southern Syria”, 4 Mart 2015, Jerusalem Center for Public Affairs, https://jcpa.org/iran-shiite-brigade-syria/ , Erişim tarihi 12.05.2020.

42 Wiebke Lamer - Erin Foster, "Afghan Ethnic Groups: A Brief Investigation", Afghanistan Thematic Report, NATO Civil-Military Fusion Center (CFC), Ağustos 2011, s. 1. 
Hazaralar'ın yoğun olarak yaşadığı bölge olan Hazaracât, Afganistan'ın orta kısmında bulunuyor olması sebebiyle istilacılardan en fazla etkilenen bölgelerden biri olmuştur. Tarihi olarak Hazaracât Hazara Hanları veya Mirleri tarafından yönetilmiştir. Bu durum Afgan hükümdarı Şir Ali Han'ın zamanına kadar devam etmiş̧ir. Şir Ali Han'dan sonra Afgan Kralı olan Abdurrahman Han, Afgan tahtına geçtikten sonra ilk iş olarak İngilizler'in yardımıyla Hazaracât' 1 istila etmiş ve Peştunlar dışındaki gruplara karşı baskıcı bir tutum izlemeye başlamıştı. Bu baskıcı tutum kapsamında Hazaralar'la birlikte Özbekler ve Nuristanlılar'1 hemen her firsatta baskılamaya çalışmıştır. Bu dönemde baskıya ve katliama uğrayan etnik gruplar ise bu durum karşısında isyan etmiş, patlak veren isyan üç yıl kadar sürmüştür. (1890-1893) Bu isyana Hazara Hanları liderlik yapmıştır. Hazaralar'ın baskı altına alınması ve öldürülmesinin ana sebebi Şii/Caferi Mezhebi'ne bağlı olmalarıdır. Abdurrahman Han, mezhep faktörünü kullanarak hem diğer etnik grupları hem de komşu Müslüman ülkeleri Hazaralar'a karşı kışkırtmayı amaçlamış, dinden çıkmış olarak gördüğü Hazaralar'a karşı Cihat fetvası yayınlanmasını sağlamıştır. ${ }^{43}$ Tüm bu gelişmeler sonrasında Abdurrahman Han döneminde Afganistan'daki Hazara nüfusunun \% 62'si öldürülmüş, esir edilen gençler İngiltere, Hindistan ve Arap ülkelerine köle olarak satılmıştır. ${ }^{44}$ Abdurrahman Han'ın Hazaralar'a karşı izlediği bu imha siyasetinden önce, 19. yüzyılda, Hazaralar'm Af Afganistan nüfusunun \% 67'sini oluşturduğu iddia edilmektedir. ${ }^{45}$

Abdurrahman Han'ın 1901 y1lında oğlu Habibullah Han tarafından öldürülmesinden sonra yeni yönetim tarafından Hazaralar'a af çıkartılmış ve Peştunlar'a verilen topraklarının bir kısmı kendilerine geri verilmiştir. Ülke yönetiminde yaşanan bu değişim ve idarenin 1lımlı tutumu üzerine Hazaralar'ın bir kısmı anavatanları olan Hazaracât' a ${ }^{46}$ geri dönmüştür. Abdurrahman Han'ın zamanında öldürülmemek için Kabil'e kaçan Hazaralar, 1929 yılından sonra kendilerine verilen firsatı iyi değerlendirmişler, başkentte olmanın avantajını ellerinden geldiğince kullanmaya çalışmışlardır. Bu kapsamda Kabil'deki Haz-

43 Abdullah Muhammedi, "Hazaralar'1n Tarihi ve Etnolojik Yapıs1”, 08.01.2009, https://guneyturkistan.wordpress.com/2009/01/08/hazaralarin-tarihi-ve-etnolojik-yapisi/, Erişim tarihi 08.02.2020.

44 Hasan Alparslan, "Unutulan Hazara Türkleri”, Bakış Gazetesi, http://www.bakisgazetesi.com/ makale/hasan-alparslan/-unutulan-hazara-turkleri/544.html , Erişim tarihi 08.02.2020.

45 Lamer - Foster, a.g.e., s. 4.

46 “Afganistan'ın ortasındaki dağllk bölgede yer alan ve Hazaracat veya Hazaristan olarak adlandırılan bölge Hazaraların en yoğun olarak yaşadıkları yerdir. Hazaracat bölgesi Bamyan, Ghor ve Day-Kundi vilayetlerinden oluşmaktadır.” Daha fazla bilgi için bkz. H. Şeriati, Ferhengi Şifahiyi Merdumu Hazara (Cüstari Der Ferhengi Ammeyi Hazarai Afganistan), Kabil, İntişarat-1 Emiri, 2004. 
aralar siyasi, iktisadi ve kültürel alanlarda etkin rol oynamaya başlamışlardır. ${ }^{47}$ Bu etkileri II. Dünya Savaşı ve sonrasındaki dönemde de devam etmiş ve 70'lı yıllara kadar sürmüştür. 1973 yılında Sovyet yanlısı subayların desteği ile Davut Han bir darbe yapmış ve Kral Zâhir Şah'ı devirmiştir. Sovyetler Birliği Davut Han'ın Afganistan Devlet Başkanı olmasına ilk başta tepki vermejten kaçınmıştır. Ancak geçmişteki olaylardan ders çıkaran Davut Han Sovyetler Birliği’ne ve ülke içindeki sempatizanlarına karşı mesafeli durmaya seçecektir. ${ }^{48}$ Afganistan'da gerçekleşen darbe sadece Zahir Şah'1 devirmekle kalmamış, Krallık yönetiminin de sonunu getirmişti. Afgan Krallığı cumhuriyete dönüşmüştü. Bu dönemde Davut Han'ın önceliği Pakistan'la olan sınır sorunu ve bu sorunun iki ülkeye yansıması olan Peştun meselesi olduğundan Hazaralar'la fazla alakadar olmadi. Hazaralar da bu durumunda faydalanma yoluna gittiler ve Afgan Devleti'nin çeşitli kademelerinde görev aldılar ve yükseldiler. Bunlardan biri de Afgan ordusunda generallik rütbesine kadar yükselen Ahmet Ali Han'dır. ${ }^{49} 1978$ Darbesi'nden önce Afganistan'daki en büyük etnik gruplardan biri olan Şii Hazaralar ülke yönetimini elinde tutan Peştunlar tarafından, Afganistan'daki tüm diğer etnik gruplarda olduğu gibi, yönetimden dışlanmaya çalış1lıyordu. Bu yüzden darbeyle yönetimi ele geçiren Nur Muhammed Taraki liderliğindeki Afganistan Demokratik Halk Partisi (ADHP) yönetimi ilk başta Hazaralar'ın tam desteğini ald1. Ancak Afganistan yönetiminde değişen birşey olmadı ve Hazaralar ADHP iktidarında da umduklarını bulamadılar. ${ }^{50}$

1978 yılındaki darbeden sonra ADHP iktidarına ve uygulamalarına karş1 muhalefet olarak ortaya çıkan Mücahitler, Komünist Hükümete karşı ülkenin çeşitli yerlerinde direnişe geçtiler. Hazaralar, 1978-1985 yılları arasında 50'ye yakın grup kurup Afgan direnişine katıldılar. ${ }^{51}$ Kendi dinî liderleri ve aydınlarının desteği ile de 1979 yılının sonunda Afganistan İslam Devrimi İttifakı Hükümeti'ni kurdular, Seyit Ali Behişti'yi de Cumhurbaşkanı olarak seçtiler. Bu tarihten sonra Hazaracât özerk bir bölge haline geldi. ${ }^{52}$ Ayrıca İran'la da ilk temaslar bu dönemde kuruldu. Bunun sonucunda 1980'li y1llar boyunca Afganistan'daki

47 Muhammedi, a.g.m.

48 Hüseyin Şeyhanlığlu, “18. Yüzyıldan Günümüze Kadar Afganistan’1n Jeostratejik Önemi”, Avrasya Etüdleri, T.C. Türk İşbirliği ve Kalkınma İdaresi Başkanlığı, sayı 34, sayı 2, 2008 , s. 70.

49 Hasan Poladi, The Hazaras, çev. Ali Alemi Kermani, Tahran, İran Yekta Yayınları, H. 1381, (1962) s. 271.

50 Farzam ve Sarı, a.g.m., s. 274.

51 Lamer - Foster, a.g.e., s. 4.

52 Toplu, a.g.m. 
Sovyet güdümlü komünist rejimle mücadele etmek üzere Hazaralar tarafindan kurulan toplam dokuz direniş grubuna İran Devrim Muhafizları'nca doğrudan para ve silah yardımı yapıld1..$^{53}$

1989 yılında Hazaralar'ın en büyük partileri bir araya gelerek Vahdet Partisi'ni kurdular. Vahdet Partisi kurulduktan 3 yıl sonra Hazaracât ve diğer Hazara yerleşim bölgelerinde denetim sağladı. Vahdet Partisi, ${ }^{54} 1991$ yılında ilk kez Afganistan'la ilgili uluslararası bir konferansa davet edildi. Hazaralar bu konferanstan sonra İstanbul'da düzenlenen İslam Ülkeleri Dışişleri Bakanları Konferansı'na da davet edildiler. Hazaralar, Taliban rejiminin ortadan kaldırılmasından sonra Afganistan'a müdahale eden ülkelerin desteğiyle kurulan Hamit Karzai başkanlığındaki Afgan Geçici Hükümeti'nde de görev aldılar. ${ }^{55}$

\section{Hazaralar'ın Etnik Kökeni}

Daha önce de belirtildiği gibi Afganistan'da birçok farklı grup bulunmaktadır. Bu etnik gruplar yüzyıllardır bir arada yaşadığı için birbirleriyle karışmışlar, aralarında kan ve akrabalık bağları kurulmuştur. Bundan dolayı Hazaralar, Afşarlar, Halaçlar gibi etnik gruplar dillerini kaybedip Farsça'nın bir kolu olan Darice ve Peştunca konuşmaya başladıkları iddia edilmektedir. Bazı Tacik gruplar da Türkçe konuşmaktadır. Bu karışım nedeni ile Afganistan'daki etnik gruplarının hepsinin etnik kökenlerinin tespiti konusu oldukça sıkıntılı bir süreç haline gelmektedir. Çünkü kaynak eksikliği ile bazı durumlarda etnik ve kültürel olarak içiçe geçmiş bir toplumsal yapı sebebiyle Batılı tarzda, sınırları kesin olarak belirlenmiş ve formüle edilmiş etnik gruplar ve kimlikler tanımlamak Afganistan' da nerdeyse imkansız hale gelmektedir. Bu kaynaşma sonucunda konuşulan dilin terkedilmesine en iyi örnek Afganistan'daki ilk Türk grubu olan Halaçlar'dır. Halaç Türkleri dillerini kaybettikleri için zaman içinde Peştunlara asimile olmuş ve Afganlaşmışlardır. Çalışmanın konusu Hazaralar'ın kökeni ise yapılan çalışmalarda Türk-Moğol ve daha çok da Moğol etnisitesine dayandırılmaya çalışılmaktadır. Türkler ve Moğollar genellikle diğer milletler tarafindan birlikte anıldıkları için "Türk-Moğol halkları", "Türk-Tatar halkları ve dilleri" gibi isimlendirmelere muhatap olmuş, bu kavram çifti kullanımı kapsamında Hazaralar da, bir kısmının morfolojik görünümlerinin de yardımıyla, çoğunlukla Moğol veya Moğol soyundan kabul edilmiştir.

53 Farzam - Sar1, a.g.m., s. 274.

54 “Afganistan'daki Hazara muhalefet grupları 1988 yılında bir siyasi parti çatısı altında birleşmişlerdir. Bu siyasi partinin adı Hizb-i Vahdet (Birlik Partisi) idi." Lamer - Foster, a.g.e., s. 4.

55 Muhammedi, a.g.m. 
Ahmet Zeki Velidi Togan Umumi Türk Tarihine Giriş isimli çalışmasında Cengiz hâkimiyetiyle beraber bazı Türk boylarının Afganistan'a göçtüğünü, Moğollar zamanında "Alay" manasında kullanılan "Hazare" ismiyle anılmaya başlandıklarını ve bu isimle de günümüze kadar geldiklerini belirtmektedir. ${ }^{56} \mathrm{Bu}$ konuda çalışan bir diğer isim olan Yaşar Kalafat ise Hazaralar'ın, Hazar (Türk Hazar Devletini kuranlar) ve Azer Türkleri (bugünkü Azerbaycan Türkleri'nin bir kısmının ataları) ile aynı milliyet grubuna ait bir topluluk olduğu iddiasındadır. ${ }^{57}$ Türk ismi daha çok Oğuz Türkleri'ni belirtmede kullanıldı̆̆ 1 için, diğer Türk olduğu ifade edilen grupların kökeni ile ilgili farklı teoriler ileri sürülmektedir. ${ }^{58}$

Çoğunlukla Afganistan'ın merkezindeki Hazaracât adı ile bilinen dağlık bölgede meskûn olan Hazaralar, Özbek, Türkmen, Tacik, Aymak ve Peştun gibi ülkenin diğer etnik grupları ile komşudurlar. Dil olarak Farsça'nın Afganistan'a özgü Hezaregi lehçesini ${ }^{59}$ kullanan Hazaralar, mezhep bakımından da Oniki İmam Şiîliği’ne bağlıdırlar. ${ }^{60}$ Sünnî olan komşularından hem dil, hem mezhep yönünden farklı olmaları, ek olarak Moğolları andıran fiziki görünümleri ile ayrılmaktadırlar. Hazaralar'ın da içerisinde bulunduğu Afgan toplumu Celaleddin Sadıki'ye göre üç ana gruba ayrılmaktadır. Bunlar:

1. Ariyalılar: Tacik, Peştun, Beluç ve Nuristanlılar,

2. Türkler: Hazara, Aymak, Özbek, Türkmen ve Kırgız,

3. Berahuyiler.

Celaleddin Sadıki'ye göre bu üç ana gruptan Türk zümresi içinde yer alan Hazaralar'ın menşeleri konusunda bu güne kadar dört farklı görüş ileri sürülmüştür. Bunlar sirasiyla;

56 Ahmet Zeki Velidi Togan, Umumi Türk Tarihine Giriş, İstanbul, Enderun Kitabevi, 1981, s. 151.

57 Yaşar Kalafat, "İsmaili Hazara Türkleri”, Yeniden Ergenekon, 19 Haziran 2008, https:// yenidenergenekon.com/274-ismaili-hazara-turkleri/ , Erişim tarihi 12.05.2020.

58 Bilgehan Atsız Gökdağ, “Afganistan'da Türklük ve Hazaralar”, Tarih Tarih, https://www.tarihtarih.com/?Syf=26\&Syz=358890, Erişim tarihi 12.05.2020.

59 "Farsça'nın bir diyalektiği olarak kabul edilen Hezaregi'de neredeyse Farsça kadar Türkçe kelime mevcut olup, özellikle bitki ve yiyecek isimlerinin tamamı Türkçe'dir.” Orhan Yazıc1, “Hazaralar'ın Kökeni ile İlgili Yeni Bir Görüş", Türklük Bilimi Araştırmaları, sayı 29, 2011, s. 477.

60 Hassan M. Kakar, A Political and Diplomatic History of Afghanistan 1863-1901, Boston, Brill, 2006, s. 129. 
1. Hazaralar'1n Afganistan'ın yerlisi olduğu görüşü,

2. Hazaralar'ın Cengiz Devleti'nin bakiyesi olan Moğollar oldukları görüşü,

3. Hazaralar'ın Moğol ve Türkler'in karışımından oluşan bir etnik grup oldukları görüşü,

4. Hazaralar'ın Afganistan'daki farklı etnik grupların karışımı sonucu ortaya çıkan bir topluluk oldukları görüşüdür. ${ }^{61}$

Bu iddia ve tanımlamalar, Hazaralar konusunda çalışan araştırmacıların teorileri olmakla birlikte halk arasında da genel kabul görebilmektedir. Son zamanlarda yapılan çalışmalarda Hazaralar hakkında yeni bir görüş daha ortaya çıkmıştır. Buna göre Hazaralar, Bamiyan ve çevresindeki Budist kültürün temsilcileri olan Demirci (Seti) kavimlerin yani Kuşan ve Eftalitlerin (Akhunlar) bakiyeleridir ve takriben iki bin yıldan beri de Afganistan'da yaşamaktadırlar. Bu görüşü ortaya koymadan önce şimdiye kadar Hazaralar'ın menşei ile ilgili araştırmacıların ileri sürdükleri iddiaları incelemek yerinde olacaktır. ${ }^{62}$

1. Hazaralar'ın Afganistan'ın Yerlisi Olduğunu Temel Alan Görüş: Hazaralar'ın Afganistan'ın yerli ahalisi olduğunu iddia eden görüş taraftarları onların İndo-Aryanlar'ın bakiyeleri olduklarını ve M.Ö. 4. Yüzyıldan beri Afganistan'da yaşadıklarını iddia etmekte idi. Bu teoriyi Fransız Oryantalist J. P. Ferrier geliştirmiş ve 19. Yüzyıl'ın ortalarında bilimsel ve akademik çevrelerde dile getirmeye başlamıştı. Ferrier'e iddiasına göre Hazaralar, M.Ö. 4. Yüzyıl'dan beri Afganistan'da yaşamaktaydılar ve Büyük İskender'in bölgeye yaptığ 1 seferde ona karşı koyanlar bugünkü Hazaralar'ın atalarıydı. Ferrier bu iddiasına dayanak olarak İskender'in tarihçilerinden Quintus Curtius'un anlattıklarını gösteriyordu. Curtius eserinde şöyle diyordu: “Aleksander, Paropamisus dă̆larının karla kaplı kuzey sırtlarından Batı'daki Bactriana'ya ilerlerken Barbarlar arasında medenî olmayan daha vahşi yerlilerle karşılaştı." İşte Ferrier'e göre İskender'in karşıs1na çıkan bu daha vahşi yerliler Hazaralar'ın ataları idi. ${ }^{63}$

Ferrier'in bu görüşünü benimseyenlerden birisi de Afgan Tarihçisi Abdulhay Habibî'dir. Habibi Hazaralar'ın, Büyük İskender'in fetihlerinden beri Afgan-

61 Muhammed Hussain, The Hazaras of Afghanistan: A Study of Ethnic Relations, Quebec, McGill University, 2003, s. 11-16.

62 Yazıc1, a.g.m., s. 477.

63 Yazıc1, a.g.m., s. 478. Daha fazla bilgi için bkz. Joseph Pierre Ferrier, Caravan Journeys and Wanderings in Persia, Afghanistan, Turkistan and Beloochistan, ed. Henry Danby Seymour, Londra, John Murray, 1857. 
lar'la beraber yaşadıklarını ve bu sebepten dolayı onların da Afganistan'ın yerli ahalisi olduklarını iddia etmişti. Ancak Habibî, Hazaralar'ın etnik ve kültürel özelliklerine değinmeden bilinçli bir şekilde sadece "Hezare" kelimesinin filolojik yapısına atıfta bulunmaktadır. Yaptığı etimolojik analizden yola çıkarak teorisini destekleyecek deliller üretmeye çalışmıştı. Bu sayede Hazaralar'ın Türk kabul edilmesi durumunda ortaya çıkabilecek istenmeyen durumların önüne geçmeye çalışmıştı. Sonuç olarak ise teorisini desteklemek için de Hezare adının sadece Afganistan'ın iç kısımlarında yaşayan halka mal edilemeyeceği, ismin kapsamının çok daha geniş bir alana yayıldığını iddialarına eklemişti. Habibi’nin tarifini yaptığı büyük Hazara bölgesinin sınırları Mahubun Dağları'nın eteklerinden başlayarak Heripur, Ebutabad, Pehleyî, Kağan'dan geçerek Keşmir Dağları'nın derin vadilerine kadar uzanmakta idi ve Hezare adı bu alanda yerleşik olan etnik grupların tamanına verilmesi gereken bir isimdi. Bu halk ne Tatar'dı ne de sarı 1rka mensuptu. Onlar Antik Çağ'da bölgede yaşamış olan İndo-Aryanlar'ın bakiyeleri idi ve konuştukları dil de İndo-Aryanların dil ailesine dahildi.

Tüm bu iddilarına ragmen Habibî, Hezar kelimesinin Moğolca “Ming” kelimesinin Farsça'daki karşılığı olduğunu da kabul etmekteydi. Fakat bununla beraber, bu kelimenin Hezare'ye dönüşmüş olabileceği ihtimalini kabul etmemişti. Ona göre, meşhur Çinli seyyah Hüan-Tsang'ın, M.S. 644 y1lında Hindistan'a yaptığ 1 seyahatten Tsu-ku-che'ye yani Arakuzya'ya dönerken, geri dönüş yolu üzerindeki ilk yerleşimi Hu-si-ne ve ikincisini Hu-sa-le olarak isimlendirmişti. Bu yerleşim yerlerinden Hu-si-ne'nin sonraki dönemlerde Gazne, Hu-sa-le'nin de Aryanca "Sevinçli-Mutlu" anlamına gelen Hezare'ye dönüştüğünü iddia ediyordu. ${ }^{64}$ Dolayısıyla bu kelimenin kökenini Moğollar'ın Afganistan'daki varlığından çok daha önceye dayanıyordu. Bu yüzden Habibi'ye göre Hezare "Bin" anlamına gelen Ming'in Farsçası ile olan benzerliği sadece bir tesadüften ibaret idi. Bu iddiasının doğruluğuna dayanak olarak Sind Nehri'nin karşı kıyısında yaşayan Pencâb Hazaraları'nı göstermekte idi. Sonuç olarak Habibî, Hazaralar'ın Cengiz Han zamanında Afganistan'a gelen askerlerin bakiyeleri olduğuna dair görüşe şiddetle karşı çıkıyordu. Çünkü Celalettin Harezmşah Etek' in güneyinde bulunan Nilâb'dan geçmiş ancak onu takip eden Cengiz Han, buradan geri dönmüş, Celaleddin Harzemşah'1 Sind Nehri'nin ötesinde, Hindistan topraklarında takip etmemişti. Bu yüzden Cengiz'in hakimiyeti hiçbir zaman Sind Nehri'nin ötesinde, yani Hindistan'da var olmamışt1. ${ }^{65}$ Ancak tüm iddialarına rağmen Habibî Afgan-

64 Abdulhay Habibi, “Aya Hezare Kelime-i Kadimter Est?” Aryana, cilt 20, say1 5, 1962, s. 19 23. Ayrica bkz. Yazıc1, a.g.m., s. 478. 
istan'daki bir coğrafi bölgenin ismi olduğunu iddia ettiği Hazara'nın nasıl bu bölgede yaşayan toplulukların ismi haline geldiğine dair makul bir açıklama getirememişti. ${ }^{66}$

Aynen Ferier ve Habibi gibi, Hazaralar'ın dil özellikleri üzerinde araştırmalar yapmış olan Moğol dili uzmanı Alman dilbilimci Mihael Weiers ise "Günümüz Herat ve çevresindeki köylerde yaşayan Afganistan Moğolları'ndan ele geçen kelime istatistikleri göstermektedir ki, iki grup (Hazaralar ve Moğollar) arasinda kök birliği mevcut değildir" diyerek, Hazaralar'ın Moğollarla aynı kökten gelmediklerini iddia etmiş ve bu yüzden Hazaralar'ın Afganistan'da Moğollar'dan çok daha önce var olan yerli halklarından biri olduğunu savunmuştur. ${ }^{67}$ Oysa Zahirüddin Muhammed Babür, Vekâyinâme adlı çalışmasında bu iddiayı yalanmamakta ve "Hezare ve Nekderîler arasında bazı kabileler Moğul dilini konuşurlar" diyerek, Hazaralar'ın konuştuğu dilde Moğolca'dan kelimelerin bulunduğunu ifade etmektedir. ${ }^{68}$ Ancak bu bölgede Cengiz Devleti'nin hakimiyeti sebebiyle neredeyse hemen her dilde ve haliyle Türkçe'de de Moğolca kaynaklı kelimeler bulunmaktadır. (örneğin Timuçin, Ögeday gibi isimler) Ancak buna dayanarak Türkler'in Moğol olduklarını iddia etmek bilimsel gerçekleri fazla zorlamak olacaktır haliyle. Benzer durum Hazaralar için de geçerlidir.

2. Hazaralar'ın Cengiz Devletinin Bakiyesi Olan Moğollar Olduğuna Dair Görüss: Hazaralar'ın kökeni ile ilgili en çok kabul gören görüş, onların Cengiz Han zamanında bölgeye gelen Moğol ordusu ve askerlerinin bakiyesi olduklarıdır. Bilindiği üzere Cengiz Han, Harezmşahlar'la girmiş olduğu mücadele sonucunda yendiği Celaleddin Harzemşah'1 takip ederken Afganistan topraklarına girmiş ve Sind Nehri'ne kadar da peşinden gitmişti. Ancak Hindistan'a girmeyip, Sind Nehri'nin kıyısından geri dönen Cengiz, Orta Asya'ya geri dönerken Afganistan'dan Hindistan'a açılan dağ geçitleri tutmak için ordusundan bir kısmını artçı olarak Afganistan'da bırakmışt. ${ }^{69}$ Hazaralar'ın Moğollar'ın bakiyesi olduğuna dair görüşün taraftarlarından olan Arminius Vambery ${ }^{70}$ Kâbil ve Herat

66 Yazic1, a.g.m., s. 478-479.

67 Michael Weiers, "The Language of the Hazara People and of the Mongols of Afghanistan", Afghanistan Journal, cilt 2, say1 3, 1975, s. 102.

68 Gazi Zahirüddin Muhammed Babür, Vekayı Babür'ün Hatıratı, cilt I-II, çev. Reşit Rahmeti Arat, Ankara, Türk Tarih Kurumu Yayınları, 1987, s. 142; Yazıcı, a.g.m., s. 479.

69 Michael Prawdin, The Mongol Empire, New York, The Free Press, 1967, s. 190-197.

70 "Adı Armin, Hermann ve soyad Wamberger, Weinberger şekillerinde de yazılır. Almanya'nın Bamberg şehrinden Macaristan'a göç etmiş dar gelirli bir Yahudi ailesinin çocuğu olarak Budapeşte 'nin kuzeybatısındaki Dunaszerdahely'de doğdu. Malî sebeplerle tahsiline devam edemedi ve çeşitli işlerde çalışırken kendini yetiştirdi. Güçlü hâfızası ve 
arasındaki dağlık bölgede meskûn olan Hazaralar'ın bu artçı kalan Moğollar'ın soyundan geldiklerini ve Şah Abbas zamanında (1571-1629) Şiî mezhebini benimsediklerini iddia etmişti. Ona göre Hazaralar, Herat yakınlarındaki dağlık bölgelerde izole edilmiş küçük bir grup hariç, zaman içerisinde etraflarındaki diğer etnik grupların konuştuğu dil olan Farsça'yı benimseyerek Moğolca konuşmayı terk etmişlerdi. ${ }^{71} \mathrm{Bu}$ görüşün savunucularından bir diğer isim İngiliz Oryantalist Mountstuart Elphinstone ise Aymaklar'la birlikte Kâbil ve Herat arasindaki dağlık bölgenin sakinlerinden olan Hazaralar'1, Cengiz'in torunu Mengü'nün ordusunun bakiyeleri olarak tarif etmektedir. ${ }^{72}$ Elphinstone, Hazaralar' $1 n$ zamanla Çağataylar'ın bakiyeleri olan Aymaklar'la evlilik yoluyla akrabalık ve kan bağı tesis ettiklerini, daha sonra da Safevîler'in etkisiyle Şiîliği benimsediklerini ve bu süreçte Moğolca konuşmayı terk edip, Farsça'nın bir diyalektini konuşmaya başladıklarını iddia etmektedir. ${ }^{73}$

dil ögrenmedeki üstün yeteneği sayesinde daha yirmi yaşına gelmeden on altı dil konuşup on ikisinde yazabildiği hâtıralarından öğrenilmektedir. Yirmi yaşında Türkçe’yi öğrenen Vámbéry, özellikle Macarca'nın menşeinin Fin-Ogur dilleri mi yoksa-kendi inandığ gibiTatarca mı (Türkçe) olduğu konusu üzerinde durdu. Daha sonra Jósef Budenz gibi bilginlerce Macarca'nın Fin-Ogur dillerinden geldiği tesbit edilmiş, ancak Vámbéry, tezini bırakmak zorunda kalmasına rağmen Macarlar'ın menşeini Türkler'in teşkil ettiğine dair görüşü sebebiyle 'Pantürkizmin Babası' olarak tanınmıştır.” Daha fazla bilgi için bkz. Turgut Akpınar, “Arminius Vambery”, Türkiye Diyanet Vakfi Íslam Ansiklopedisi, cilt 42, İstanbul, 2012, s. 501-502.

71 Arminius Vambery, Travels in Central Asia, Londra, John Murray, 1864, s. 264. Eserin Türkçesi için bkz. Cemal Kutay, Sahte Derviş, İstanbul, Aksoy Yayıncılık, 1998.

72 “1830'lu yıllarda Afganistan ve Türkistan'ı keşif ve istihbarat toplama amactyla dolaşmış olan İngiliz hükümeti görevlilerinden Alexander Burnes da tutmuş olduğu gezi notlarında Hindikuş Dağları ile Bamiyan arasında kalan bölgede yaşayan Hazaralar için, Tatar Hazaralar terimini kullanmış ve onların Cengiz'in ordusunun bakiyeleri olduğunu belirtmiştir." Alexander Burnes, Travels into Bokhara I-II, Londra, John Murray, 1839, s. 265.

73 Mountstuart Elphinstone, An Account of the Kingdom of Caubul III, Londra, Richard Bentley, 1842, s. 202. Yazic1, a.g.m., s. 480.

19. yüzyılın önemli araştırmacılarından olan Henry Walter Bellew, "The Races of Afghanistan" adlı eserinde şöyle der: "Gazne'den Kâbile, Herat 'tan Kandahar'a kadar çok geniş bir alanda meskûn olan Hazaralar' 'n bu ülkenin diğer bütün halklarından farklı olduğunu belirtmektedir. Bellew'e göre Hazaralar, 13. yüzyllın ilk çeyreğinde Cengiz tarafindan binerli gruplar halinde ayrllarak, Afganistan'ın merkezine yerleştirildi. Cengiz ülkesine dönüşünde onlardan on grubu kontrolü sağlamaları için Afganistan'da bıraktı. Bunlardan dokuzu Hezare-i Kâbil'de ve onuncusu ise İndus'un doğusundaki Hezare-yi Pekli (Pehleyi)de iskân edildi. Bölgenin Afgan ahalisi yanında Çar Aymak, Cemşidî, Firuzkûhî, Taymanî ve diğer Tatar zümrelerle temas eden Moğol askerleri zamanla kendi ana dillerini unutarak, içerisinde pek çok Türkçe kelimenin de bulunduğu Farsça'nın yeni bir diyalekti olan Hezaregi'yi konuşmaya başladılar. 15. yüzyılda 
20. yüzyılın hemen başlarında Afganistan'a giden Osmanlı aydınlarından Mehmed Fazlı, Hazaracât'a da gitmiş ve Hazaralar'ın Türkistan Türkleri ile benzerliklerine oldukça şaşırmıştı. Bu benzerliğe olan hayretini ise şu şekilde kelimelere dökmüştü:

"Cengiz Han ile beraber gelip bu havaliyi vatan tutmuş binlerce Cengiz efrâdl, artık bu diyarın ahâlisi olup kalmış ve batından batına tamamen yerleşmiş ise de bugün bile kiyafet ve simâları Rusya Türkleri'nin tipkisidir." "74

Hazaralar'ın Moğolların bakiyeleri olduklarına dair görüşe, Rus Tarihçi Vasilij Vladimiroviç Barthold da katılmaktadır. Afganistan'ın merkezinde yer alan Kûhistan vilayetinde sakin olan halkın çoğunluğunun Afgan olmayan unsurlardan meydana geldiğini ve bu ahali içerisinde öne çıkanların Çar Aymaklar ile Hazaralar olduğunu söyleyen Barthold, Bend-i Türkistan'dan Herirud Vadisi'ne kadar yayılan bu ahalinin yarı göçebe bir hayat tarzına sahip olduklarını belirtir. Afganistan'ın daha zengin ve gelişmiş diğer vilayetlerindeki ahaliden gelenek ve görenek bakımından farklı olan bu grubun dil ve lehçe bakımından da diğer gruplardan faklı olduklarını aktarmaktadır. Ona göre Hezare kelimesi, Farsça Hezar kelimesinden gelmektedir ve Moğol Ordusu'nun Afganistan'da kalan ve iskân edilen unsurlarına İranlılar tarafından verilen addır. İranlılar tarafından verilen bu ad daha sonra Afganistan'daki tüm gruplar tarafından benimsenmişti. Ancak Barthold Hazaralar'ın kökeninin Moğollar'a dayandığı iddiasına katılsa da, Hazaralar'1 Cengiz'in değil, onun meşhur Komutanlarından Nikûder'in bakiyeleri olarak kabul etmekteydi. ${ }^{75}$ Ona göre;

Safevîler 'in hâkimiyetlerini Kandahar'a kadar ilerletmesi neticesinde de Şî̂liği benimsediler." Bkz. Henry Walter Bellew, The Races of Afghanistan, Calcutta, Thacker-Spink and Co., 1880, s. 113.

"1954 yllında Afganistan'da Hazaralar hakkında bir araştırma yapan Wilfred Thesiger, Afganistan'in merkezinde yaşayan Hazaralar'in Moğol asıllı olduklarından bahisle, Çingiz Han 'in haleflerinden Mengü Han zamanında Gurîler'in ülkesine gönderilen askerî unsurların bölgede yerleştiklerini ve zamanla kendi dillerini bırakarak, Farsça konuşmaya başladıklarını iddia etmektedir." Bkz. Wilfred Thesiger, "The Hazaras of Central Afghanistan", The Geographical Journal, cilt 121, say1 3, Eylül 1955, s. 313.

74 Mehmed Fazlı, Afganistan'a Seyahat, haz. Ali Ahmetbeyoğlu, İstanbul, Selis Kitaplar, 2008, s. 59.

75 “Tarih-i Raşidî’yi neşreden N. Elias, esere eklediği açıklamalar bölümünde, Afganistan Hazaraları'nın Moğollar'ın bakiyesi olarak yüksek dağlar arasındaki izole edilmiş vadilerde yaşadıklarını aktarmaktadır. Ancak Elias, onların Cengiz zamanında değil, Hülagü'nun oğlu olarak zikrettiği Nikudar Oğlan ile birlikte 13. yüzyılın ikinci yarısında bölgeye geldiklerini ve burada yerleştiklerini ileri sürmektedir. Ona göre, bugün hala onların konuştukları 
“Yüksek tepelerin ve dă̆llk bölgelerin işgali, Moğollar'in büyük zorluklar çekmesine sebep olmuş, sonuçta komutanlar askerlerini bu bölgeden çekmek zorunda kalmışlardı. Ancak başka Moğol kuvvetlerinin ulaşmasından sonra saldırlarına devam edebilmişlerdi. Onlar kendi Hanlarının adıyla tanınıyorlardı; onların en meşhurlarından birinin adı 'Nikuderîler' idi ki, 13. yüzyılda Çă̆atay zamanında bu bölgeye iskân edilmişlerdi. "76

Yazarı belli olmayan ancak Meryem Mirahmedî tarafından yayınlanan $\mathrm{Ne}$ jad-nâme-i Afgan adlı eserde ise Hazaralar'ın Moğol ve Tatarlar'ın bakiyeleri olduğu iddia edilmektedir. Eserde; Tacik, Özbek ve Afgan aşiretleri ile komşu halde, Belh'ten Kâbil'e, Kandahar' dan Herat'a kadar uzanan dağlık bölgede yaylak kışlak hayatı yaşayan ve Day-i Zengî, Day-i Kundî, Day-i Mirdad, Day-i Mirkşe, Day-i Mirk, Day-i Çopan, Day-i Hıtay, Day-i Nurî, Day-i Mirî, Daye, Behsûd ve Cagûrî olmak üzere on iki büyük kola ayrılmış olarak yaşayan Hazaralar'ın, oldukça misafirperver ve savaşçı özellikleriyle meşhur olan bir halk olarak tarif edilmektedir. ${ }^{77}$

3. Hazaralar'ın Moğol ve Türkler' in Karışımından Oluşan Bir Etnik Grup Olduklarına Dair Görüş: Bu görüşün taraftarları, Hazaralar’1 13. yüzyılın başlarından 15. yüzyılın ortalarına kadar olan zaman diliminde Afganistan'1n dağlık bölgelerine yerleşen Moğol ve Türk gruplarının bakiyeleri olarak değerlendirmektedirler. Cihangir'in 'Münşisi Nimetu'l-lah'ın, Mahzân-1 Afgan̂̂” adlı eserini inceleyen ve yayınlayan Bernard Dorn, açıklayıcı notlar kısmında "Hazaralar'ın Hülâgu zamanında 100.000'den fazla çadır ahalisi olarak Gazne'den Kandahar'a ve oradan Belh sınırlarına kadar yayıldıklarını ve bu bölgede deve, at, koyun ve keçi yetiştiriciliği yaptıklarını” ifade etmekte idi. Dorn ayrıca Hazaralar'ın Mengü Han tarafından Nikuder'in komutası altında Kâbil'e gönderildiklerini ve Hazaralar arasında komutanları Nikuder'e ithafen bir kabilenin Nikuderîler olarak adlandırıldığını belirtmektedir. Dolayısıyla Dorn'a göre, Hazaralar ne sadece Moğol, ne de Türk'türler. Her iki milletin karışması sonucunda ortaya çıkan yeni bir etnik gruptur.

Hazaralar konusunda çalışan bir başka araştırmacı olan Elizabeth E. Bacon da, Hazaralar'ın Türk-Moğol kökeninden geldikleri iddiasındadır. Bacon, çalışmasında Hazaralar'ın menşei ile ilgili tartışmaları ortaya koyduktan son-

Farsça'da Moğolca pek çok kelimenin varlı̆̆ı bunu teyit eder mahiyettedir. ” Yazıcı, a.g.m., s. 481 .

76 Yazıc1, a.g.m., s. 481-482.

77 Meryem Mirahmedî, "Nejad-nâme-i Afgan", Journal of Historical Research, cilt 1, sayı 2, İlkbahar 1989, s. 1-81. Yazıc1, a.g.m., s. 482. 
ra, onların sadece Moğollar'ın bakiyesi olmadıkları, aynı zamanda Çağatay ve Timurlular zamanında bölgeye gelen Türkler'le karıştıklarını iddia etmektedir. ${ }^{78}$ Elizabeth Bacon'a göre Hazaralar'ın ortaya çıkışı şu şekilde olmuştur:

“Afganistan'da Moğollar'in tarihî geçmişi göstermektedir ki, Hazaralar'ın menşei konusunda yeni yazarların açıklamaları sthhatli değildir. Mevcut kaynaklar Cengiz Han'in, Horasan, Gûr ve Gazne istikametine birkaç defa ordu sevk ettiği, o kuvvetler hedeflerine ulaşttktan sonra tekrar bu mintıkadan çekildikleri yönündedir. Çingiz Han'ın hangi daimi kuvvetini bu bölgede bırakttğına dair bir işaret yoktur. Çingiz'in, Moğollar'in yerleşmesi için bir yol olarak dağllk bölgenin (Kûhistan) ahalisinden bir bölümünü katlettirmiş olması da mümkündür. Günümüzde 'Hazaracât' olarak adlandirllan bölgede ilk defa Maveraünnehr Çağatayları yerleşmiş, daha sonra başka Moğollar ve bazı Türk grupları ya da Türkomoğollar onlara katılmışlardır. Horasan'da yerleşik ordular, İlhanlı hâkimiyeti aleyhine defalarca isyan etmişlerdi. Bu muhaliflerden bazllarının, takipten kurtulmak maksadıyla merkezî Afganistan'daki dağlara çekilerek burada saklanmış olmaları kuvvetle muhtemeldir. Sonraları Timur ve oğlu Şahrûh zamanında bu bölgeye askeri birlikler sevk edilmişti. Muhtemelen Timurlular'ın Semerkand'a dönüşünden sonra onlardan bazlları bu bölgede kalmışlardl. Bu yüzden mevcut Hazara Moğolları'nın soyu sadece Cengiz Han'ın göndermiş olduğu askerlerden gelmemektedir. Aksine Çağataylar zamanında başlayıp 1447'de Şahruh'un idaresinin sonuna kadar devam eden süreçte bölgeye akan Türkler'in bu ahaliyle karışmasından meydana gelir." 79

Bu sayılanlara ek olarak Bacon, Hazaralar arasındaki önemli kabilelerden biri olan Poladîler'in, Timur'un ünlü komutanlarından Pir Muhammed Polad'ın soyundan geldiklerini ileri sürmüş ve Polad (veya Polat/Pulat-Türkçe "Çelik" demektir) isminin Türkçe olduğuna ve Moğollar arasında bulunmadığına da dikkati çekmiştir. ${ }^{80}$ Bacon'un idddialarını destekleyen Longworth M. Dames de Hazaralar'la ilgili şu bilgileri paylaşmaktadır:

“Afganistan'da, Hazara ismi, Helmand ve Tarnak vadilerinin kuzey ve güney taraflarındaki dağllk mıntıkada yerleşmiş bulunan kavme ver-

78 Elizabeth E. Bacon, "The Inquiry into the History of the Hazara Mongols of Afghanistan", Southwestern Journal of Anthropology, cilt 7, say1 3, İlkbahar 1951, s. 234-241. Ayrica bkz. Rene Grousset, Bozkır İmparatorluğu, çev. M. Reşat Uzmen, İstanbul, Ötüken Neşriyat, 1993, s. 322.

79 Bacon, a.g.m., s. 234-241.

80 Bacon, a.g.m., s. 245. 
ilen addır. Hudûtları; Kuzey'de-Hindukuş ve Koh-i Baba'ya kadar, Güney'de-Herat civarına ve Harûd Vadisi'ne kadar gider; mamafih bu mıntıkanın güneyinde kalan kabilelere Çahar Aymak ismi verilir. Aymaklar Hazaraler'den din ve dil itibarl ile ayrllılar; zira bunlar Sünnî olup, Türkçe konuşurlar; hâlbuki Hazaraler Şi'î olup, Farsça konuşurlar. Bununla beraber, bunlar da asıllart itibart ile, çehrelerinin de gösterdiği gibi, Türk-Moğol ırkına mensupturlar... Hazara ismi, şüphesiz, Türkçe ming (bin) kelimesinin Farsça 'ya tercümesidir ve Moğol ordularının bin'er kişilik birlikleri ile alakadardır. Bütün bu araziye, sakinleri dolayısı ile, Hazaristan yahut Hazaracat yani "binler" ismi verilmştir." 81

Bu konuda çalışan bir başka araştırmacı olan Klaus Ferdinand da Hazaralar' ın dış görünüş itibarıyla Moğollar'a benzediklerini ve içerisinde Türkçe ve Moğolca kelimeler bulunan Farsça'nın bir diyalektini konuştuklarını aktarmaktadır. Yine Ferdinand'a göre Hazaralar çok büyük bir ihtimalle Ortaçağ'da Afganistan ve Horasan havalisine Moğollar tarafından yapılan akınlar sırasında ve sonrasında bölgede yerleşmiş grubun torunlarıdır ve Türkler ile Moğollar'ın karışması ile ortaya çıkmışlardır. ${ }^{82} \mathrm{Bu}$ sayılanlarla aynı istikamette görüş belirtmekle birlikte Afgan tarihçisi Feyz Muhammed Han Hazaraları Moğollar'dan ziyade Türklükle irtibatının oldukça güçlü olduğunu iddia etmiştir. Ona göre Hazaralar:

"Hazaralar, kendilerini 'Cagûrî' olarak isimlendirirler. Timurun komutanlarından Butay Buga'nın komutası altında Afganistan'a gelmişlerdir. Hazaralar'ın içerisindeki büyük aşiretlerden birisi olan Şeyh Ali taifesi kökenini Türk olarak bilir ve delil olarak da aralarında Türkmen olarak tanınan bir grubun mevcudiyetini gösterir. Yine onların arasında Halaç ve Karluk Türkleri'nden gruplar vardır ki Hazaralar'ın atalarını teşkil ederler. Onlar Moğol hücumlarından önce şimdi merkezî Afganistan adıyla isimlendirilen bu mıntıkada oturuyorlardı." "83

4. Hazaralar'ın Afganistan'daki Farklı Etnik Grupların Karışımı Sonucu Ortaya Çıktıklarına Dair Görüş: Bu görüşe göre Hazaralar ne sadece Moğol, ne de Türk ve Moğollar'ın karışması sonucu oluşan bir topluluktur. Türkler ve Moğollar Hazaralar'1 oluşturan gruplardandır ama onlara ek olarak Afganistan'da yerleşik Tacikler, Araplar ve Peştunlar gibi diğer grupların da birbiri ile karışması sonucunda ortaya çıkmışlardır. Cengiz Han'ın Türkistan ve İran’ı is-

81 Yazic1, a.g.m., s. 484.

82 Klaus Ferdinand, "Nomad Expansion and Commerce in Central Afghanistan: A Sketch of Some Modern Trends", Folk, cilt 4, 1962, s. 125.

83 Yazıc1, a.g.m., s. 485. 
tilası sırasında bölgeye gönderilen Moğol birlikleri stratejik açıdan önemli noktalarda kalıcı karakollar kurmuş ve bu alanlara da kalıcı olarak yerleşmişlerdi. Cengiz zamanında başlayan bu durum halefleri olan İlhanlılar ve Çağataylar zamanında da sürmüştür. Bölgeye eşleri olmadan gelen Moğol ve Türk askerî unsurları, zamanla bölgenin yerlileri olan Tacik, Peştun ve Araplar'la evlilik yoluyla kaynaşmışlar, böylece Farsça konuşan komşularının nüfuzları altına girerek yeni bir lehçe olan Hezaregi’yi konuşmaya başlamışlardır. Sonuçta Hazaralar, 13. yüzyıldan 15. yüzyıla kadar geçen dönemde merkezî Afganistan'a gelen Türk ve Moğollar'ın, bölgenin yerlileri olan Farslar, Araplar ve Afganlar ile etnik ve kültürel olarak kaynaşması sonucu ortaya çıkmışlardır.

Bu görüşü ilk defa öne süren kişi, 1962 yılında yayınladığ 1 "The Mongols of Afghanistan; An Ethnography of the Moghols and Related People of Afghanistan" adlı çalışması ile Franz Schurmann olmuştur. ${ }^{84}$ 1950'li yılların sonlarında Afganistan'da araştırmalar yapan Schurmann, mavi gözlü, sarı saçlı Mongolid bir zümre ile karşılaştı̆̆ını ve bölgede yaptığı araştırmalar neticesinde ayrı ve parçalanmış gruplar halinde yaşayan Moğollar'ın, Hazaralar ve Aymaklar'la bir akrabalığı olmadığını, aynı şekilde Hazaralar ve Aymaklar arasında da yakın bir akrabalık bulunmadığını iddia etmiştir. Ortaya çıkan sonuç; ismi geçen $\ddot{u} c ̧$ grubun, yani Moğollar, Hazaralar ve Aymaklar'ın halihazırda kültürel ve etnik farklılıkları sebebiyle ayrı gruplar olduklarıdır. Bu yüzden Schurmann Hazaracât Hazaraları'nın, Kûhistan bölgesinin yerli İranlılar' $\imath$ ile Moğol işgalcilerin karışması sonucu ortaya çıkmış bir grup oldukları iddiasındadır. ${ }^{85}$

Hazaralar'ın farklı etnik grupların karışması ve asimilasyonu sonucu ortaya çıktığını savunan isimlerden bir diğeri de M. Hassan Kakar'dır. Kakar, Hazaralar'ın halis Moğol ya da Türk oldukları iddiasına muhalif olmakla birlikte Hazaralar'1 Afganistan'a gelen Cengiz Moğolları'nın ama daha çok da Çağataylar'ın bakiyeleri olarak görmektedir. Kakar'a göre Çağataylar 1229 ile 1447 yılları arasında muhtelif zamanlarda Afganistan'a girmiş ve 16. yüzyılda Hazara adı ile anılacak olan zümreyi teşkil etmişlerdir. Bekâr olarak ya da eşlerini bırakarak buraya gelmiş olan askerlerin, merkezî Afganistan ve çevresindeki yerli Berber halkının (Tacik) kadınlarıyla evlendiklerini ileri sürmektedir. Ona göre, İran menşeli ve Farsça konuşan Tacikler ile akrabalık, yeni gelenlerin dilleri üzerinde tesir bırakmış ve içerisinde pek çok Türkçe kelimenin de bulunduğu Hezaregi denilen yeni bir lehçenin meydana gelmesine sebep olmuştur. Dolayısıyla Kakar'a

84 Daha fazla bilgi için bkz. Franz Schurmann, The Mongols of Afghanistan; An Ethnography of the Moghols and Related People of Afghanistan, The Hague, Mouton, 1962.

85 Schurmann, a.g.e., s. 109. 
göre Hazaralar; Moğol, Türk, Tacik gibi toplulukların karışımından meydana gelmiştir ve 13. yüzyıl ile 16. yüzyıl arasında Afganistan'da yeni bir etnik grup olarak ortaya çıkmışlardır. ${ }^{86}$

Hazaralar'ın kökenini açıklığa kavuşturma konusunda 4 ayrı yaklaşım bulunmakta, hemen hepsi de Hazaralar'ın kökenine 1ş1k tutmaya çalışmaktadır. Teorilerin hemen hepsindeki ortak nokta Afganistan'a dışarıdan gelen farklı milliyet gruplarının, ki bunlar Moğollar ve Türkler oluyor, yerli halk ile kaynaşarak dillerini unuttukları veya dillerinin birbirine karışması sonucunda yeni bir etnisite ortaya çıkardıklarıdır. Bu teori elbette doğru olabilir ancak hakim güç olan Moğollar'ın neden dilleri terk ettikleri ve Afganistan'a dişarıdan gelenler sadece Moğollarsa Hazaralar'ın bugün konuştukları dildeki Türkçe kelimelerin kaynağ1 ve neden gündelik hayatta yaygın olarak kullanılan sebze-meyve ve yemek isimleri vb. değişmeden kaldığı konusuna bir açıklama getirememektedir.

Sonuç olarak, Hazaralar'ın etnik kökeni, kimliklerinin kaynağı hakkında tam bir uzlaşı yoktur. Aksine ortaya konan deliller ve teoriler birbirleri ile çelişebilmektedir. Çünkü hem kaynak eksikliğ hem de Hazaralar'in kendi kökenleri konusunda net bir bilgiye sahip olmaması işleri zorlaştırmaktadır. ${ }^{87} \mathrm{Bu}$ sayılanlara ek olarak Batılı araştırmacıların bir çoğu Hazaralar üzerinde araştırma yaparken Hazaracât'a gitmemişlerdir. Büyük bir kısmı çalışmalarında ikincil kaynakları kullanmıştır. Bu da rasyonel sonuçlara ulaşılmasını engellemektedir. ${ }^{88}$

\section{Hazaralar'ı Oluşturan Boylar}

Hazaralar 13. yüzyıla kadar, yani Cengiz dönemine kadar, Hazara adıyla anılmamışlardır. Bu dönemden önce Hazaralar, Türk, Tatar, Türkmen, Zavuli, Berberi, Halaç, Karluk, Çağal, Laçın ve Garçe gibi isimlerle anıldıkları iddia edilmektedir. ${ }^{89}$

Hazaralar üç büyük boya ayrılmaktadır. Bu boylar; Besud, Ceguri ve Uruzgani' dir. Safkan Hazaralar olarak adlandırılan Besudlar, genellikle dağlık ve yüksek bölgelerde diğer Hazara gruplarından izole olarak yaşamaktadırlar. Peştun ve Tacikler'le karışık olarak yaşayan ve onların kültür çevresine girmiş olan grup

86 Kakar, a.g.e., s. 123.

87 Jennifer Ruth Creasy, "The Religious Identity of the Hazaras of Afghanistan and Modern-day Pakistan”, (Yayımlanmamış Yüksek Lisans Tezi), Glasgow, University of Glasgow, Temmuz 2009.

88 Poladi, s. 61.

89 Muhammedi, a.g.m. Ayrıca bkz. Hac Kazım Yezdani, Defâi Hazaraha Az İstiklal ve Tamamiyeti Arzi-yi Afganistan, Kum, Ahmet İhsani Yayınları, Hicri 1368 (1949), s.147-178 
ise Ceguri Hazaraları'dır. Uruzganiler ise daha çok Afganistan'ın Uruzgan ve Day-kundi vilayetlerinde yaşamaktadırlar. Afganistan'da yaşayan Özbek, Kırgız, Türkmen vb. Türk grupları ile Hazaralar'ı morfolojik olarak birbirlerinden ayırmak oldukça zordur. ${ }^{90}$

Tatar Hazaraları; Hazaracât ile Türkistan arasında bulunan Deşt-i Sefid Bölgesinde yaşamaktadırlar. Türkmen Hazaraları; Hazaracâtın kuzeydoğusunda bulunan Türkmen Vadisi'nde (Derreyi Türkmo) yaşamışlardır. Tolun Hazaralar1; Behsud kabilesi'nin Day Mirdad'ın bir alt koludur. (Misır'da devlet kurmuş olan Tolunoğullarıyla bir bağlantıları olup olmadĭ̆ tespit edilememiştir.) Çağal Hazaraları; Hazaracât'ın batısında ve Nave-Miş bölgelerinde yaşamaktadırlar. Torhan Hazaraları; Hazaracât' 'n Bamyan ve Gur vilayetlerinde yerleşiktir. Laçın Hazaraları; Belh civarında, Belhab ve Seng Çarek’te yaşamaktaydılar. Ancak Moğollar bu bölgelere girmeden önce Hindistan'a gitmişlerdir. Hindistan tarihinin ünlü isimlerinden Emir Hüsrev Dehlevi ${ }^{91}$ Laçın Hazaraları’ndandı.

90 Komite-i Dini Siyasi ve Ferhengi (Dini, Siyasi ve Kültürel Komite), Coğrafya, Kabil, İntişarat-1 Vezaret-i Maarif-i Afghanistan (Afganistan Milli Eğitim Bakanlığı Yayınları), 2011.

91 Emir Hüsrev Dehlevi: "Emîr Hüsrev b. Emir Seyfeddîn Mahmud-ı Dihlevî 651/1253 yılında Delhi'de doğdu. Türkistan'da Lâçin isimli Türk kabilesi'nden olan babası Seyfeddin Mahmud Moğol istilasında Belh 'ten Hindistan'a gelip yerleşti. Burada Delhi Sultanı Şemseddin Iltutmuş'un hizmetine girdi ve dönemin vezirlerinden emir Imadülmülk'ün kızlyla evlendi ve bu evlilikten ortancası Emîr Hüsrev olmak üzere üç oğlu oldu. Seyfeddin Mahmud ölünce Emîr Hüsrev'le dedesi Emir Imadülmülk ilgilendi. Emîr Hüsrev dedesinin huzurunda yapılan edebi ve ilmi sohbetleri dinleyerek yetişti. Dedesi öldükten sonra bir süre Delhi sultanlarından Balaban Han'ın küçük oğlu Buğra Han'ın hizmetine girdi ve daha sonra Mültanlı Prens Muhammed Kaan Mâlik'in davetini kabul edip onun nedimlerinden oldu. Mültan'da ünlü şair Hasan-i Dihlevi ile tanıştr. Kaan Mâlik'in Moğollar tarafindan öldürüldügü savaşta Emîr Hüsrev, Hasan-i Dihlevi ile birlikte esir düştü. Emîr Hüsrev esaretten kurtulduktan sonra Sultan Balaban Han'in hizmetine girdi ve saray şairi oldu. Fîrûz Şah Halacî döneminde sarayda mushafdarlık yapan Emîr Hüsrev, Fîrûz Şah Halacî'nin yerine geçen Sultan Alâeddin Halacî'den gerekli ilgiyi göremediği için Nizâmeddin Evliyâ'ya intisap etti. Emîr Hüsrev, Sultan Alaeddin'in vefatından sonra Kutbüddin Mübarek Şah döneminde eski itibarını kazandı. Şeyh Nizâmeddin Evliyâ'ya daima bağlılık gösteren Emîr Hüsrev, Sultan Glyaseddin Tuğluk zamanında Bengal seferine katıldı̆̆ esnada Nizâmeddin Evliyâ'nın öldügünü duyunca Delhi'ye döndü ve bir süre inzivaya çekildi. 725/1325 yılında Delhi'de öldü. Farsça, Türkçe, Arapça ve Hintçe'yi ve bu dillerin edebiyatlarını bilen Emîr Hüsrev, musiki ilmine de vakıftı." Bkz. Yasemin Yaylalı, "Emîr Hüsrev-i Dihlevi'nin Bir Gazelinin İncelenmesi”, Atatürk Üniversitesi Edebiyat Fakültesi Dergisi, sayı 63, Aralık 2019, s. 554-555. Emir Hüsrev Dehlevi hakkında daha fazla bilgi için bkz. Erkan Türkmen, “Emir Husrev-i Dehlevi'nin Urduca'nın Doğuşundaki Rolü”, Selçuk Üniversitesi Edebiyat Fakültesi Dergisi, say1 2, 1983, s. 21-32 ve Erkan Türkmen, Emir Hüsrev-i Dehlevi'nin Hayatı, Eserleri ve Edebi Şahsiyeti, Ankara, Atatürk Kültür Dil ve Tarih Yüksek Kurumu, 
Zavuli Hazaraları; Hazaralar'ın en kalabalık grubunu Zavuliler oluşturmaktayd1. Hatta bugünkü Hazaracât bölgesinin adı eski kaynaklarda Zavulistan olarak da geçmekte idi. Bugün ise Zavuliler; Caguri, Malistan ve Uruzganda yaşamaktadırlar. Son olarak Karluk Hazaraları da Hazaracâtt'a bulunan Şeyh Ali'de yaşamaktadırlar. ${ }^{92}$

Hazaralar içerisinde Torhan ve Laçın Hazaraları hariç diğer kollar hâlâ varlıklarını sürdürmektedir. Hazaralar, tek bir etnik gruptan meydana gelmemektedirler. Ülkenin güneyinde yaşayan Hazaralar ile batısında yaşayan Hazaralar arasında yüz yapılarındaki bu farkı açıkça görmek mümkündür. ${ }^{93}$

Hazaralar, yaşadıkları yerlerin isimleri ve mensup oldukları boy isimlerine göre sınıflandırılmaktadır. ${ }^{94}$ Ayrıca bazı Hazaralar'ın boy isimleri Day ile başlamaktadır. Day ile başlayan Hazara boyları, Hazaralar'ın en kalabalık boylarını meydana getirmektedir. Bu boylara ait alt gruplar da mevcuttur. Day, güçlü ve cesur anlamlarına gelmektedir. Bu kelime Çinliler'den Moğollar'a, Moğollar'dan da Hazaralar'a geçmişti. ${ }^{95}$

Hazaralar'1 oluşturan boyların hepsinin isimlerini zikretmek mümkün değildir. Burada Hazaralar'ın en önemli ve en kalabalık boyları ve yaşadıkları yerler hakkında kısaca bilgi verebiliriz:

1. Day Kalan: Hazaralar'in en kalabalık boylarından birisidir. Day Kalanlar birbirinden ayrı olarak Hazaracât'ın güneybatısı ile kuzey doğusunda yaşamaktadırlar.

2. Day Zengi: Day Zengi Hazaraları da Hazaracât’ta oldukça geniş bir alana dağılmış olarak yaşamaktadırlar. Yaşadıkları yerler: Pencab, Veres, Yekev-Leng, La'l ve Seri Cengel'dir.

Atatürk Kültür Merkezi Yayını, say1 29, Türk Fikir ve Sanat Adamları Dizisi, say1 6, 1988. Ayrıca bkz. Gülhumar Togçiyeva, "Hindistan'ın Dudukuşu”, Atatürk Üniversitesi Türkiyat Araştırmaları Enstitüsü Dergisi, sayı 15, 2000, s. 147-151.

“Emir Hüsrev Dehlevi, Urduca'nın banilerinden, Davul ve Sitar'ın mucidi olarak bilinir." Daha fazla bilgi için bkz. Mehmet Erkan Kıllıoğlu, “Türkçe'nin Hint Dilleri'nin Oluşumuna Olan Etkisi”, Yedi İklim Dergisi, sayı 224, Kasım 2008.

92 Yezdani, a.g.e., s.178-184.

93 Muhammed İsa Garcistani, Hazara ve Hazaristan, Koveyte, Şura-yi Ferhangi İslami Afganistan Yayınları, 1989, s. 63.

94 Bilgehan Atsız Gökdağ, “Afganistan'da Türklük ve Hazaralar”, Türkler Ansiklopedisi, cilt 20, Ankara, Yeni Türkiye Yayınları, 2002, s. 706.

Yezdani, a.g.e., s. 313. 
3. Day Çopan (Day Çoban): Day Çopanlar'ın bir çoğu Afganistan'ın güneyinde toplanmıştır. Day Çopan'ın bir çok alt kolu mevcuttur. Day Çopanlar kendilerini Emir Çopan'ın Oğulları olarak da isimlendirmektedir. Emir Çopan, Sultan Ebu Said İlhanlı'nın en önemli komutanlarından birinin adıdır. Emir Çopan, Sultan Ebu Said'in emriyle H. 725 (1325) y1lında Mekkeye içme suyu getirmek için Arafat'tan Mekke'ye kadar içme suyu kanalı inşa ettirdiği için dinî açıdan da önemli ve saygı gören bir kişidir.

4. Day Hata: Day Hata Hazaraları Uruzgan, Gizab ve Kicran'da yaşamaktadırlar.

5. Day Kundi: Day Kundi hem Hazaralar'ın bir boyu hem de Hazaracât'ın bir şehridir. Day Kundi en kalabalık Hazara boylarından biridir. Day ile başlayan diğer Hazara boyları şunlardır: Day Polad, Day Mirek, Daye, Day Mirkeşe, Day Mirdad, Day Deko (Day Dehkan), Day Kuzi, Day Ziniyat, Day Melik, Day Birke, Day Nuri, Day Miri, Day Digek, Day Hakkani, Day Kalender, Day Hoten ve Day Kiyu. ${ }^{96}$

6. Badehşi Hazaraları: Bu Hazaralar, Afganistan'ın Katagan ve Badehşan vilayetlerinde meskundur. Bu boy diğer Hazara boylarından uzak yaşadıkları için diğer boylar tarafindan Hazara olarak kabul edilmemektedir.

7. Kunduz Hazaraları: Kunduz vilayetinde yaşamaktadırlar. Kunduz Hazaraları'nın bir kısmı Şii/Caferi diğerleri ise Sünni/Hanefi'dirler.

8. Laçın Hazaraları: Cengiz Han'a karşı savaşmışlar ve bu savaştan mağlup çıkınca cezalandırılmamak ve Cengiz'in idaresi altına girmemek için Hindistan'a göç etmişlerdi.

9. Hulm Hazaraları: Afganistan genelinde oldukça geniş bir sahaya yayılmışlardı. Timur zamanında Timur'un hizmetine girmişlerdir.

10. Kayan Hazaraları: Afganistan'ın en verimli ve yeşil vadilerinden biri olan Kayan Vadisi'nde yaşamaktadırlar. Kayan Hazaraları İsmaili mezhebine mensupturlar.

11. Kuzey'deki Hazaralar: Kuzey vilayetlerinin çeşitli yerlerinde dağınık bir şekilde yaşamaktadırlar. 
12. Pençşir Hazaraları: Pençşirdeki 7 vadinin nüfusunun önemli bir kısmını Pençşir Hazaralar'1 oluşturmaktadır.

13. Moğol Hazaraları: Bunlar Gur, Ferah, Herat, Bağlan ve Seripul'da yaşamaktadırlar.

14. Tatar Hazaraları: Bunlar geniş bir alana dağılmış halde yaşamaktadırlar ve Hanefi mezhebine mensupturlar.

15. Nikuder Hazaraları: Bunlar Sultan Ahmet Nikuder İlhanlı'nın soyundan gelmektedirler. (Nikuder, Müslüman olduktan sonra Ahmet ismini almıştır.)

16. Badgis Hazaraları: Badgis Hazaraları, Horasan ve Kaleyi-Nevde yaşamakta ve Day Ziniyat Hazaraları olarak bilinmektedirler. Day Ziniyat Hazaraları'nın bir kısmı İran'da yaşamaktadır.

17. Sorhu Parsa Hazaraları: Pervan vilayetinin batısı ve Hazaracâtın kuzeydoğusunda bulunan Lulenc şehrine bağlı olan Sorh ve Parsa vadilerinde yaşamaktadırlar. Diğer Hazara grupları ise Kolhol ve Kolliç Hazaraları, Badrav Hazaraları, Bağal Hazaraları, Gudey Hazaraları, Cerman Hazaraları, Loger Hazaraları, Pektiya Hazaraları ve Çaç Hazaraları'dır. Bunlar Hazaracât'ın çeşitli yerlerinde ve Afganistan'ın güneyinde hâlâ yaşamlarını sürdürmektedirler. ${ }^{97}$

\section{Hazaralar'ın Dinî ve Kültüirel Özellikleri}

Hazaralar Türkçe'den ziyade Farsça (Hazaragi ve Dari-Afgan Farsçası-lehçeleri) konuşmaktadırlar. Hazaralar'ın Farsça'yı tercih etmelerinde baskı ve zulme karşı kendilerini koruma iç güdüsünün ağır bastığı ve bunun diğer Türk etnik yapılarını da etkilediği iddia edilmiştir. Bugünkü Hazara dili aslında Farsça olmakla birlikte içinde birçok Türkçe kelime bulunmaktadır. Bunlardan bazıları Çağatay Türkçesi kökenlidir. Hazaralar'ın sözlü halk edebiyatında Türk dünyasının tamamında rastladığımız Ergenekon Destanı, Köroğlu Destanı, Ferhat ile Şirin Hikayesi, Keloğlan Masalları, Nasrettin Hoca fikraları bulunmaktadır. Dinî inanç açısından Hazaralar'ın büyük çoğunluğu Şii' dir ancak aralarında Sünni olanlar da vardır. ${ }^{98}$ Hindukuş dağlarında yaşayan küçük bir grup ise İsmai-

97 Yezdani, a.g.e., s. 285-305.

98 "Çoğunluğu Oniki İmamcı Şii olan Hazaralar arasında, Oniki İmamcı Şiilik dışında, az sayıda da olsa İsmaili Şiilik ve Sünnilik de görülmektedir. Badgis, Şeyh Ali ve Fizurgah Hazaralar genellikle Sünni'dir. Kayan Hazaraları Ísmaili'dir. Çoğunluğu oluşturan Bamyan bölgesi Hazarları Oniki İmamcı'dır.” Zahide Ay, "Hazaraların Şiileşmesinde Safevi Etkisi”, Selçuk Üniversitesi Türkiyat Araştırmaları Dergisi, sayı 47, Aralık 2019, s. 397. 
li ${ }^{99}$ inancına mensuptur. ${ }^{100}$ İsmaili olan Hazaralar dini inanç ve ritüellerinde etkisi yoğun bir şekilde görülebilen Müslümanlık öncesi inançlar ve eski bölge dinlerinin (Tengricilik-Kamizm gibi) izleri yoğun bir şekilde görülmektedir. Bu kültürel ve dini öğeler yüzünden bazı araştırmacıların Hazaralar'ın Farsça konuşsalar da aslen Türk oldukları veya Türk kültürünün bir parçası olduklarını düşünmelerine sebep olmuştur. Bu düşüncenin haklı olduğu noktalar vardır, özellikle de bölgede daha önce hüküm sürmüş olan Büyük Selçuklu Devleti'nin bilim dilinin Arapça, Devlet dili'nin ise Farsça olduğu düşünülürse. ${ }^{101} \mathrm{O}$ yüzden dış görünüş olarak

99 “Ísmailiye Şia'nın bir kolu, bir firkasıdır. Şiilikteki mutediller ile müfritler arasındaki ihtilafin bir ürünüdür. Hz. Ali neslinden 6. Imam Hz. Ca'far ül-Sadık vefatından sonra vuku bulmuştur. İsmail Cafer'in büyük oğlu ve halefi idi, ihtilaf sonucu hilafet küçük kardeşi Musa'ya geçti. Musa'nın ve varislerinin imametli Isna Aşeriye tarafindan hala tanınmaktadır. Ismailiye mezhebinin ihtilalci temellerini Abul Hattab kurmuştur. İsmaililer arasinda hilafet devam ederken bu inancın mensuplarından çok büyük ilahiyatçılar görsel felsefi seviyede bir dinî akaidi meydana getirdiler. Büyük edebiyatçılar yetiştirdiler. İsmaili akaidin Sünni İslam'la pek az münasebeti vardır. Fikirlerinin çoğu orta şarkın daha eski dinlerinden ve bilhassa yeni eflatuncu felsefeden gelir. Fikirlerin büyük çoğunluğu batınidir. Tevil yolu ile ithal edilmiştir. Batıni tabirine İsmaililer sebep olmuştur. Kur'an ve bütün dini ahkâmın iki manası vardır. Biri harfi ve zahiri diğeri yalnız müritlerin bildiği mezact ve batıni manadır. Hz. Ali'nin İsmail yolu ile halefleri olan imamlar ilahi ilhama malik ve hatadan salim olup, saliklerinin kendilerine kaylt ve şartsız itaatini isterler. Bayram gibi günleri astronomi ile hesaplarlar. İslamiyet üzerinde fevkalade fikrî terörleri olmuştur. Fatımiler'den önce ve sonra da Orta Doğuda etkili olmuşlardır. Hasan Sabbah, Alamut Kalesi, Haşhaşılar İsmaili tarihinin safhalarını teşkil eder. 10. asırdaki Rasail İhvan el-Şafa, İsmaililik akait kitabıdır. Ünlü Nasir Husrav İsmaili idi. Müfrit Şiilik, menşelerinden itibaren, memnun olmayan sınıfların mevcut nizama karşı isyanlar ile yakından alakalı oldular. Ísmaililik uzun süre, gerek içtimai, gerek kavmi bakımından tazyik gören sinfflar ile gayri memnun münevverler üzerinde cazip bir tesir icra etmiştir. Ísmaililer 'in İslami esnaf ve fütüvvet teşkilatlarında rolleri olduğu da gözlenilmektedir. Gizli kalabilen, örgütlenebilen iyi propaganda yapabilen mazlumlara adalet fikri taşıdığını savunan bu firka dai tipinin de yaratıcısıdır. Dürzîler ve Karmatiler bu firkanın tezahürüdürler ... Hazaralar'da tek evlilik vardır. Ancak çocuğu olmayan tekrar evlenebilir. Her zaman söz, büyük hanımdadır. İsmaililer'de eşini boşamak çok zordur. Boşanmayı ancak Pir yapabilir. Bunlarda Cem yoktur. Cemaat hane vardır. Cemaat hanede dini eğitim yapılır, dua edilir, nikâh klyılır. Ancak namaz kllınmaz. Namaz ancak cami de kllınır. Cemaat hanenin hemen yanında cami vardır. Ayrıca Ağa Han'ın doğum günü veya imam olduğu zaman kutlama törenlerine gelinir. Cemaat evine ve dışına İsmaililer 'in bayrağı asılır. Bu bayrak eski Mısır Fatımileri'nin bayrağı olup yeşildir, ortasında kırmızı çizgi vardır.” Farnad Daftary, Muhalif İslam 'ın 1400 Yılı Ísmaililer, Tarih ve Kuran, ter. Ercüment Özkaya, İstanbul, Raslantı Yayınları, 1999; Ayrıca bkz. Mustafa Öz - Mustafa Muhammed eş-Şek’a, “İsmailiyye”, Türkiye Diyanet Vakfi Íslam Ansiklopedisi, cilt, 23, İstanbul, 2001, s. 128-133.

100 Lamer - Foster, a.g.e., s. 4.

101 'Selçuklular zamanında resmî yazışmalarda Amîdülmülk el-Kündürî ve Nizâmülmülk'ün ve- 
bir İranlı'dan daha çok Kırgız, Kazak veya Özbek'e benzeyen gerek Hazaralar gerekse de Tacikleri hemen peşin hükümle Farisi bir topluluk olarak tanımlamak doğru bir yaklaşım olmayacaktır. Hazaralar'ın yarı göçebe karakterleri Bozkır Medeniyeti'nin zamana uymuş biçimidir, denilebilir. Müslümanlığa geçişle birlikte kadim Kam kültü yerini Pir kültüne bırakmış görünmektedir.

Milli çalgı olarak Kopuzu kullanan Hazaralar Kopuzun yanında Gijak adında bir çalgı daha kullanmaktadırlar. Gıjak, temelde kemençe türü bir müzik enstrümanıdır. Çoğunlukla düğünlerde ve eğlencelerde çalınır. Ailede mutlaka bir Gıjak çalan olur. Gıjakla çalınan parçaların hemen hepsi Farsça'dır ve daha ziyade İran kaynaklıdırlar.

İsmaili Hazara Türkleri'nde cem ayini yoktur. Hz. Ali ile ilgili ilahiler ( $g a-$ zel-beyit) okunur. Bütün Afganistan İsmailileri'nin lideri olan Seyit Nadir Şah Kayani aslen Hazara'dır ve Tacikler ve Peştunlar gibi diğer etnik gruplardan da müritleri vardır. Eskiden beri Hazaralar'da tarikat bağları etnik bağlardan önce gelmekte idi. Ancak bu durum Afganistan'da yıllardır süren iç savaş ve istikrarsızlıktan sonra değişime uğramış, etnik aidiyet duygusu tarikat bağlarının önüne geçmiştir. Afganistan'da Taliban yönetimini de tecrübe eden Hazaralar arasında artık bu yüzden milliyet, dinî inancın önünde gelmektedir.

zirliği döneminden itibaren Farsça kullanılmış, resmî yazı̧̧maların yanı sıra birçok edebî eser de bu dilde yazılmıştır." Daha fazla bilgi için bkz. Osman Gazi Özgüdenli, "Selçuklular", Türkiye Diyanet Vakfi Íslam Ansiklopedisi, cilt 36, İstanbul, 2009, s. 365-371.

"Büyük Selçuklular Arapça'yı din ve bilim dili, Farsça'yı edebiyat ve devlet dili, Türkçe'yi ise saray ve orduda günlük konuşma dili olarak kullanıyorlardl." "Büyük Selçuklu İmparatorluğu", Vikipedia, https://tr.wikipedia.org/wiki/B\%C3\%BCy\%C3\%BCk_Sel\%C3\%A7uklu_\%C4\%B0mparatorlu\%C4\%9Fu\#Devlet_Yap\%C4\%B1s\%C4\%B1_ve_Y\%C3\%B6netimi, Erişim tarihi 18.05.2020.

"İslâmiyet'ten sonra Iran bölgesine uzanan ilk Türk devleti olan Gazneliler'den (352582/963-1186) itibaren Farsça, Türk devletleri tarafindan devlet dili olarak kullanılmıştır." Adnan Karaismailoğlu, "Tarih Boyunca Türkler ve Farsça: Modern Yaklaşımlara Bir Eleştiri”, Sosyalbilimler, cilt 3, sayı 1, Ocak 2013, s. 7.

"Gazneliler döneminde resmî dil daha çok Farsça'dır. Çăgatay ve Timurlular devrinde de Fars dili devlet ve sanat dili olarak kullanılmıştır. Büyük Selçuklular'da da resmî dil Farsça'dır. Bilindiği gibi, ilerleyen yüzyıllarda Farsça'nın saray dili, yönetim dili, ve edebiyat dili olarak kullanımı İran coğrafyasını aşarak, Gazneviler'le Hindistan'a, Samaniler 'le Orta Asya 'ya ve Selçuklularla Anadolu'ya kadar yayılmıştır. Iran topraklarındaki Türk egemenliği Selçuklular ile de somutlaşacak şekilde devlet ilişsilerinde dilin Farsça olmasına neden olmuştur. 13. yüzyılda Anadolu'da resmî yazı dili olarak Farsça kullanılıyordu. İstanbul'un fethi sırasında Fars dili resmî dil, yazışma dili ve hatta şiir ve edebiyat dili idi." Karaismailoğlu, a.g.e., s. 7-8. 
Hazara toplumunun kanaat önderleri Pirler'dir. Bir kişinin Pir olabilmesi için Ehlibeyt soyundan gelmesi şarttır. Pir ölmeden önce erkek çocuklarından birine el verir ve pirliği ona bırakır. Kızlardan Pir olmaz. Onlar "Bibi” olarak bilinirler. ${ }^{102}$ Bibi sadece Pir'in büyük kızıdır. Toplum nezdinde itibarı vardır ve hemen her konuda ona da danış1ır, fikri alınır. Pir eğitim görse de görmese de Pir'dir. Bir ailede birden fazla Pir olmaz. Pir makamını miras bırakacağı oğlunu yanından ayırmaz.

Yeni doğan çocuğa isim konulacağı zaman Pir'e gidilir. Çocuğa önce isim verilir, daha sonra Pir dua okur. Çocuğun kulağına ezan, doğduğunda ailede okunur. Çocuğun doğduğu yere erkek giremez. Ezan evin önünde daha ziyade erkek çocuk için okunur. Kadınlar dışarıya haber verirler. Son zamanlarda silah da atılmaya başlanılmıştır. İsimlerin sonuna muhakkak Ali ismi eklenir. Mehmet Ali, Seyit Ali gibi. Seyid-Pir'e gidilirken eli boş gidilmez, mutlaka hediye götürülür. Her İsmaili esasen gelirinin onda birini Pir'e verir. Kişiler bunu bizzat kendileri götürür ve elden teslim eder. Uzakta olanlar için ise Pir'in halifesi 4-5 kişilik heyet ile dolaşıp yardım paralarını toplar. Doğum esnasında Kurban kesilir. Etinden herkese ikram edilir.

Sünnette Pir'in rolü yoktur. Kurban kesilir, tek bir çocuk için sünnet yapılmaz muhakkak toplu şekilde yapılır. Askere giderken, evlenirken, gurbete çıkarken, kan davaları ve diğer anlaşmazlıklarda Pir'e gidilir. Pir'in sözü kanundur.

Aileden birisinin ölümü halinde yaslı aile ile 3 gün komşular ilgilenir. Pir yakın çevrede sadece Aksakalların cenazesine gider. Vefatı takip eden 6. günde kadınlar evi toplayıp yıkamaya başlar. 40 günde hayrat yapılıp mezara gidilir. Ancak Pir'in kırkla bir ilgisi yoktur.

Pir ölünce çevreden gelebilen bütün halk toplanır, müridi olmayan, Sünni, Şii vs. herkes gelir. Defin aynıdır. Pir'in mezarı kutsaldır. Müritlerden hastası olanlar her türlü deva için Pir'e gider. Muhakkak mezarda bir hayvan kesilir. Pir'in mezarında dua edip talepte de bulunulur. Büyük Pirlerin mezarına para bırakılır. Kadın veya erkek mücavirler bu parayı alırlar. Mücavir yoksa fakir çocuklar alır. Pir'in mezarının toprağı şifa için yenebilir. Ancak mezara taş yapıştırmak, çaput bağlamak gibi uygulamalar yoktur. Pir mezarları kolay ulaşılacak yerlerde olur. Her evin, köyün bir Pir'i olmaz. İsmaili Hazaraların bir tek Pir'i vardır. Pirlerin isimlerinin başına muhakkak "Seyit" kelimesi eklenir. Sadece Pirler 4'e kadar eş alabilirler. Muta nikâhı İsmaili ve Şii Hazaralar’da yoktur.

102 Türkiye Türkçesinde "Bibi” Hala demektir. Türk Dil Kurumu Sözlükleri, https://sozluk.gov. tr/?kelime=BAKIRSI , Erişim tarihi 21.05.2020. 
Hacı olmaya Mekke'ye gidilir. Kerbela'ya pek gidilmez. Hacca gidene "Hac1" denir. Birden fazla hacca gidenlere "El Hac" denir. İsmaili Hazaralar'ın dinî kitabı Nasır-Kusrev'in (Mervli bir Türkmen, Çăgrı Bey'in başlangıçta Hanefi olan Veziri) yazdığ 1 "Vecidin" isimli bir kitaptır. Vecidin aslında Caferi Fıkhını münazaralı olarak açıklayan şerh şeklinde bir eserdir. Kitapta namaz bahsi olmadığı için Bamyan'daki Hazaralar Şii akaidine göre, Semangan ve Bağlan'daki İsmaili Hazaralar Sünni akaidine göre namaz k1larlar. ${ }^{103}$

Hazaralar hakkında bu genel bilgileri verdikten ve onları tanıdıktan sonra Hazara Fatımiyyun Tugayı'nın kuruluşu ve faaliyetleri konusuna geri dönebiliriz.

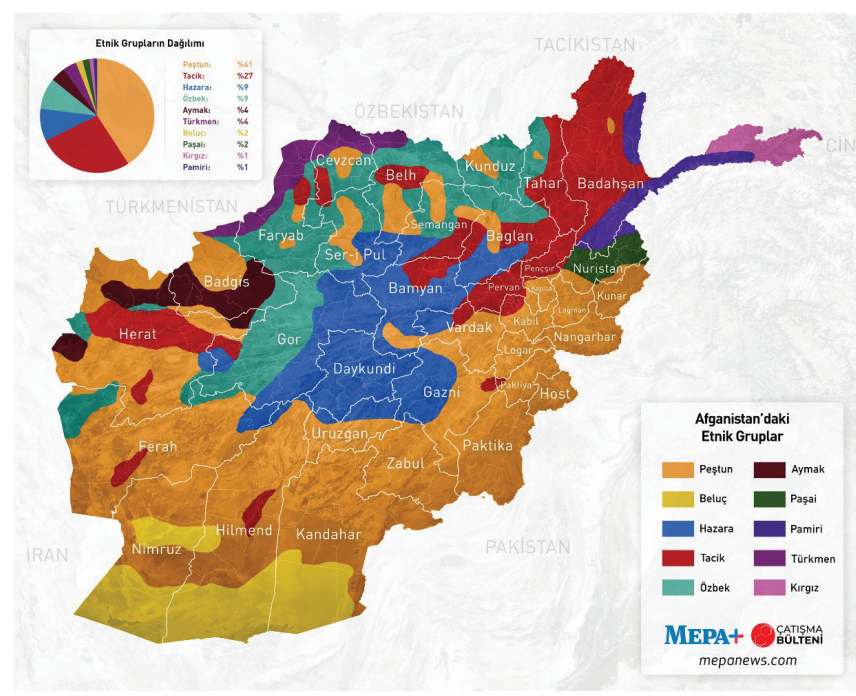

Resim 2. Afganistan Etnik Grup Haritas1. Kaynak: Mepa News, 27 May1s 2019, (https:/www.mepanews.com/afganistan-etnik-grup-haritasi-21807h.htm),

(Erişim Tarihi: 27.04.2020)

\section{Hazara Fatımiyyun Tugayı'nın Kuruluşu}

Suriye İç Savaşının 2011 yılında patlak vermesinden bir yıl sonra Beşşar Esed yönetimine karşı ayaklanan Suriye muhalefeti karşılarında kendileri ile savaşan Mısır, Yemen ve özellikle de Afganistan'dan gelenler başta olmak üzere, farklı milletlerden gelen paralı askerlerden oluşturulan bir güç olduğunu iddia ediyordu. Bu iddianın bir kısmı muhalif gruplardan birinin kendisinin Afgan olduğunu kabul eden bir milisi esir alması ile doğrulanmış oldu. ${ }^{104}$ 
Bu Hazara milisin muhaliflere esir düşmesinden sonra Suriye'deki Şii Afgan savaşçıların varlığı daha çok dile getirilir olmuştur. Tamamı Şii Hazaralardan oluşan Afgan milisler İran Devrim Muhafizlar'ının bünyesinde ve komutası altında görev yapmakta ve en tehlikeli cephe hatlarına gönderilmekteydi. İran'da yayın yapan Kayhan Gazetesi'nin bu Tugay'da görev yapmış eski milislerle yapmış olduğu bir mülakatlarda da ifade edildiği üzere ilk başta küçük bir grup olarak kurulan Fatımiyyun Tugayı'nın ilk ismi "Muhammed Müfrezesi" idi. ${ }^{105}$ Birlik ilk kuruluşunu takiben Afgan Savaşı'nda Sovyetlere karşı savaşmıştı. İran-Irak Savaşı sırasında Humeyni'nin çağrısına uyarak İran safında Irak'a karşı savaşan birlik bu savaşın sona ermesi üzerine bu sefer de 1990'lı yıllarda Taliban'a karşı savaşmak için Afganistan'a geri döndü ancak bir süre sonra dağıtıldı. 2001 yılında ise yeni Afgan Hükümeti ve ABD destekli koalisyon güçlerinin tepkisinden çekindikleri için Afganistan'1 tekrar terk etmek zorunda kaldılar.

Fatımiyyun Tugayı Suriye İç Savaşı'nda görev almak üzere Şam’a gönderildiği zaman başlarında Ali Rıza Tavassuli vardı. Ebu Hamid lakaplı Tavassuli İran'ın Meşhet şehrinde yaşıyordu ve Kum Üniversitesi'nden mezun olmuştu. Tavassuli'nin 22-25 kadar milisle Meşhet'ten Şam'a Seyyide Zeynep Türbesi’ni korumaları için gönderilmesini Molla Muhammed Bakır Alayi önermişti. ${ }^{106}$

Press News Agency, 23 Nisan 2015, https://www.khaama.com/syrian-rebels-capture-4-afghans-including-teenager-boys-1022/, Erişim tarihi 11.02.2020.

David Kenner, “Afghan Militants Join Syria’s Civil War, As If It Wasn't Awful Enough”, Foreign Policy, 4 Aralık 2013, https://foreignpolicy.com/2013/12/04/afghan-militants-join-syrias-civil-war-as-if-it-wasnt-awful-enough/, Erişim tarihi 11.02.2020.

Fassihi, Farnaz, "Iran Pays Afghans to Fight for Assad, Offers Them \$500 Stipend, Residency Benefits", The Wall Street Journal, 22 May1s 2014, https:/www.wsj.com/articles/iran-recruiting-afghan-refugees-to-fight-for-regime-in-syria-1400197482 , Erişim tarihi 11.02.2020.

Sara Elizabeth Williams, "Afghan Fighters an Increasingly Significant Player on Syrian Battlefield”, Midlle East Eye, 22 Haziran 2015, https://www.middleeasteye.net/news/afghan-fighters-increasingly-significant-player-syrian-battlefield , Erişim tarihi 11.02.2020.

“2012 yılı Ekim ayında Muhalif Özgür Suriye Ordusu'na bağlı gruplar Murteza Hüseyin isimli bir Afgan Şii milisi yakaladıklarını açıklamışlardır.” Philip Smyth, "Iran's Afghan Shiite Fighter in Syria", The Washington Institute, Policy Watch 2262, 3 Haziran 2014, https://www. washingtoninstitute.org/policy-analysis/view/irans-afghan-shiite-fighters-in-syria , Erişim tarihi 11.02.2020.

105 Bkz. Tobias Schneider, "The Fatemiyoun Division: Afghan Fighters in the Syrian Civil War", Middle East Institute, Policy Paper, 2018-9, Washington, Ekim 2018, s. 1.

106 'Ísmi için Kuzey Afrika'da 9091171- yılları arasında hüküm sürmüş olan Şii Fatımi Devleti'nden esinlenilen Fatımiyyun Tugayı'nın adı Suriye'de ilk kez 2014 yılında Şam 'ın güney kısmında bulunan Seyyide Zeynep Cami yakınlarında yaşanan çatışmalarda duyuldu." Neriah, a.g.m. 
$\mathrm{Bu}$ önerisi İran Yönetimi tarafından kabul gördü ve böylece Fatımiyyun Tugayı'nın temelleri atılmış oldu. İranın Dini Lideri Ali Hamaneyin sözcüsü olarak da bilenen Kayhan Gazetesi ise başta Tabur olan bu birliğin kuruluşunda İran'ın dahlinin bulunmadığını, Tavassuli ve 25 kadar milis ile Suriye'ye gitmeye ve Şam'daki Seyyide Zeynep Türbesi'ni korumaya gönüllü olduklarını iddia etti. ${ }^{107}$ Ancak Seyyide Zeynep Türbesi'nin bulunduğu bölge sadece manevi değeri olduğu için önemli olan bir bölge değildi. İran ve Esed Rejimi açısından stratejik önemi olan bir bölge idi. Mahalle, Şam'ın savunulması için olmazsa olmazd1. İran'ın Şam havalisinde uzun vadede düzenlemeyi planladığ 1 operasyonlar açısından da hayati önemde idi. Seyyide Zeynep semti kaybedilirse muhalifler Batı Şam bölgesindeki rejim mevzilerini kuşatabilecek ve Suriye Rejimi'nin Şam Uluslaraarası Havaalanı'na olan erişimini kesecekti. ${ }^{108}$

Tavassuli İran Devrim Muhafızları Kudüs Gücü Komutanı Kasım Süleymani'nin kendi adıyla anılan planı kapsamında Fatımiyyun Tugayı'nın başına getirilmişti. Süleymani kendi adını verdiği planında dünyanın her tarafından, ama özellikle de Afganistan, Pakistan, Irak, Suriye, Yemen ve Lübnan'dan 150.000 Şii gönüllüyü İran'ın yanında savaşmaları için seferber etmeyi planlıyordu. ${ }^{109}$

Grup, Suriye'deki ilk günlerinde Iraklı Keta'ib Seyyid el-Şüheda isimli milis grubu ile yakın işbirliğine girmişti. ${ }^{110}$ Tavassuli'nin Suriye'deki faaliyetlerini duyuran İran bu sayede sayısı yüzlerle ifade edilen Hazara'yı da gruba katılmaya ikna etti. ${ }^{111}$ Bunlardan bazıları Şam'da yaşıyordu. İlk başlarda 15 ve 22 kişiden oluşan iki birliği olan Fatımiyyun Tugayı bu sayede Suriye İç Savaşı'ndaki görevine de başlamış oldu. Ancak adı tugay olsa da yeni gelen gönüllülerle önce tabur seviyesine çıkan grup çok daha sonra tugay mevcuduna ulaşabildi.

107 Ali Alfoneh, "Shia Afghan Fighters in Syria", Atlantic Council, 19 Nisan 2017, https://www.atlanticcouncil.org/blogs/syriasource/shia-afghan-fighters-in-syria/, Erişim Tarihi: 12.03.2020.

“...Tahran yönetimi, Şii kutsal mekânları koruma bahanesiyle doğrudan Suriye’ye asker göndermiştir. Ancak savaşın şiddetlenmesiyle askeri kaybı artan Iran, Devrim Muhafizları aracılığıyla Suriye'de savaşmak üzere yabancılardan oluşan milis gücü oluşturma kararı almıştır.” Fazram - Sarı, a.g.m., s. 277.

108 Fulton - Holliday - Wyer, a.g.e., s. 25. Ayrica bkz. Joseph Holliday - Michael Lynch, "The Battle for Damascus: The Current State of Play," Institute for the Study of War, Aralık 2012. 109 Neriah, a.g.m.

110 “Şüheda Grubu Keta'ib Hizbullah 'tan 2013 yılında ayrılmış bir fraksiyondu." Bkz. Schneider, a.g.e., s. 2.

111 Kayhan Gazetesi'ne göre Tavassuli Şam'da yaşayan 5.000 kadar Şii Afgan'ı da gruba katılmaya ikna etmişti. Ancak çalışmanın ilerleyen kısımlarında da değinileceği üzere Şam'daki Hazara toplumunu toplam sayısının 2.000 civarında olduğu ifade edilmektedir. Daha fazla bilgi için bkz. Alfoneh, "Shia Afghan Fighters in Syria...". 
Grubun kurucusu olarak ismi geçen Ali Rıza Tavassuli 80'li yıllarda Afganistan'dan İran'a göç etmişti. İran'da Devrim Muhafizları'na bağlı çoğu Afganistan'lı Şiilerden oluşan A(E)büzer Tugayı'na katıldı. ${ }^{112}$ Tugay, İran-Irak Savaş1 sırasında İran'ın kuzey bölgesindeki Ramazan Garnizonu'na gönderildi. Tugay burada hem Irak birlikleri hem de İran'daki ayrılıkçı Kürt gruplarla çıkan çatışmalarda görev aldı. Dönemin resmi rakamlarına göre Tugay’daki Afganların 2.000 kadarı İran-Irak Savaşı sırasında öldürüldü. ${ }^{113}$ İran-Irak Savaşı'nın sona ermesini takiben Tavassuli 1990'l1 yıllarda ise Taliban'a karşı savaşmak için ülkesi Afganistan'a geri döndü. 2006 yılında İsrail'in Lübnan'ı işgalinde ise Lübnan'da idi. ${ }^{114}$ Tavassuli, 2015 yılında Güney Suriye'de, Deraa Vilayeti'nde bir çatışmada öldürüldü. ${ }^{15}$ Cenazesi İran'a gönderildi ve Meşhet'te gömüldü. ${ }^{116}$ Tavassuli döneminin diğer Fatimiyyun komutanları; Seyyid Hâkim, Hüseyin Fedai Abderçaya, Rıza Havari ve Seyyid İbrahim idi. (Bu kuşaktan en son sağ kalan kişi olan Seyyid Hâkim de 2016 yılında Suriye'de öldürüldü.) Tavassulinin yardımcısı olan Rıza Bahşi de (İran'da doğup, büyümüştü.) kendisinden 10 gün önce öldürülmüştü. Her ikisinin de ölümünden sonra tugay doğrudan Devrim Muhafizları'nın idaresine verildi. ${ }^{117}$

İran, dikkatleri Suriye'deki artan askeri mevcudiyeti ve yapılanmasından başka tarafa çekebilmek için Suriye rejimi safında gönüllü savaşan Şii Hazaralar konusunu bilinçli olarak gündeme taşıdı. İran'ın resmi söylemine göre Hazaralar'ın kendisi ile organik bir bağı yoktu; Afganlar hem Şam'daki Şiiler için kutsal olan yerleri hem de 1990'lı yıllardan beri Şam'da Seyyide Zeynep Camii etrafındaki bölgede toplanmış olan Hazara topluluğunu Sünnilerden korumak için gönüllü

112 “Tavassuli 1984 yılında Ebuzer Tugayl’na katılmak üzere İran'a geldi. Ebuzer Tugayı İran Devrim Muhafızları Bağımsızlık Hareketleri Bürosu'nun (Defter'i Nehzatha'i Rahe'i Bahş) Afganistan kolu idi." Alfoneh, "Shia Afghan Fighters in Syria..."

113 Schneider, "The Fatemiyoun Division, s. 3.

114 “İran-Irak Savaşı 1988 yılında sona erince Tavassuli Taliban'a karşı mücadele etmek için Afganistan'a geri döndü. 90'll yıllarda Taliban'a karşı savaştı.” Alfoneh, "Shia Afghan Fighters in Syria". Ayrica bkz. Schneider, a.g.e., s. 3.

115 “Suriye'de görev yapan Fatımiyyun Tugayı'nın Afgan Şii Komutanı ve Iran yanlısı en önemli milis liderlerinden birisi olan Ali Rıza Tavassuli 28 Şubat 2015 'te Deraa'da öldürüldü. Tavassuli, Devrim Muhafizları Kudüs Gücü'nün Komutanı Kasım Süleymani'ye olan yakınlı̆̆ ile biliniyordu." Neriah, a.g.m.

116 Neriah, a.g.m.

"Diğer 900 kadar teyit edilmiş kayıpta olduğu gibi, cenazesi Iran'a gönderildi ve orada gömüldü." Alfoneh, "Shia Afghan Fighters in Syria..."

117 Schneider, a.g.e., s. 3. 
oluyorlardı. ${ }^{118}$ İran ise sadece Afganların Şam'a ulaşmasına aracılık ediyordu. ${ }^{119}$ Oysaki savaştan önce sayıları ancak 2.000'i ancak bulan Şam'daki Hazara topluluğu, başta İran olmak üzere, hiç kimsenin dikkatini çekmemişti. Zaten 2013 yılı itibarıyla da büyük bir kısmı ya Suriye'den ayrılmıştı ya da çatışmaların daha az olduğu, nispeten sakin yerlere göç etmişlerdi. ${ }^{120} \mathrm{Bu}$ topluluğun Fatımiyyun Tugayı'na önemli bir katkısı ya da desteği olmadı. İran ve Devrim Muhafızları da tugay mensuplarının Şam'daki Hazaralarla irtibat kurmasına müsaade etmediler. Bu yüzden tugay mensuplarının camiyi ziyaretleri Devrim Muhafizları'nın yönetim kadrosu tarafından çok önceden planlandı ve sıkı bir şekilde takip edildi. ${ }^{121}$

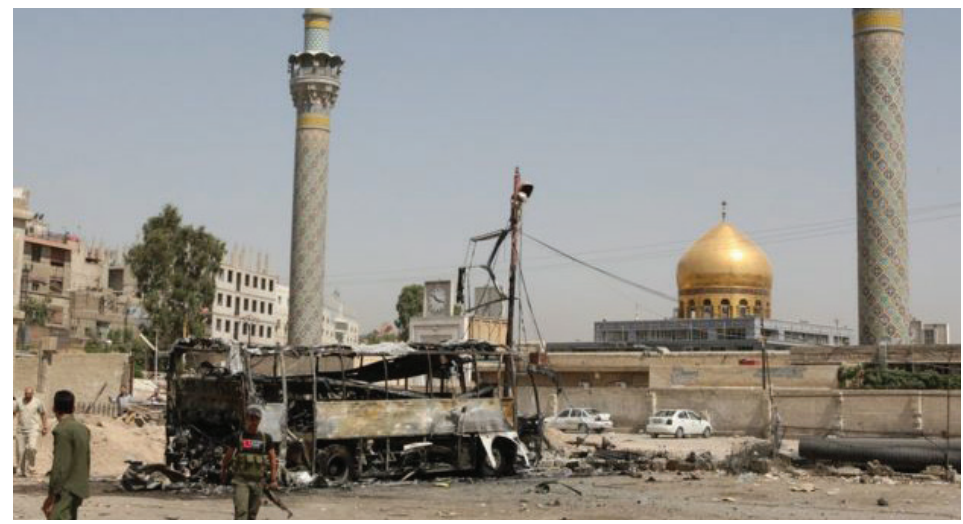

Resim 3. Şam'daki Seyyide Zeynep Türbesi. Kaynak: Fariba Sahraei, "Syria War: The Afgans Sent by Iran to Fight for Assad”, BBC, 15 Nisan 2016, (https://www.bbc.com/ news/world-middle-east-36035095), (Erişim Tarihi: 04.05.2020)

118 "Iran yönetimine göre, Şii Afganlar sadece dindar gönüllülerdi." Pamela Constable, "Recruited by Iran to Fight for Syrian Regime, Young Afghans Bring Home Cash and Scars", The Washington Post, 29 Temmuz 2018, https:/www.washingtonpost.com/world/asia_pacific/recruited-by-iran-to-fight-for-syrian-regime-young-afghans-bring-home-cash-and-scars/2018/07/29/ ecf9e34c-64e0-11e8-81ca-bb14593acaa6_story.html, Erişim tarihi 28.04.2020.

119 “Ancak Ali Alfoneh, Suriye'de savaşırken ölen ve Iran'da gömülen Afganlıların cenaze törenlerine Iranlı yetkililerin katılmasının bu durumu yalanladığını iddia etmektedir." Esfandiari, a.g.m. "Iran, Suriye'deki rejimi ayakta tutabilmek için kendi askeri güçlerinin iç savaşta görev aldlğını gösteren raporları reddetmektedir. İanlı resmi görevliler ayrıca Suriye'de savaştırılmak üzere ülkede yaşayan Afganlılar'ın askere alındiğını da yalanlamaktadır.” Esfandiari, a.g.m. Ayrica bkz. Smyth, a.g.m.

120 Ahmad Shuja, "Syria's Afghan Refugees Trapped in Double Crisis", UN Dispatch, United Nations News and Commentary, Global News Forum, 28 Ocak 2013, https://www.undispatch. com/syrias-afghan-refugees-trapped-in-a-double-crisis/ , Erişim tarihi 06.03.2020.

121 Ahmad Shuja Jamal, "Mission accomplished? What's next for Iran's Afghan fighters in Syria”, War on the Rocks, 13 Şubat 2018, https://warontherocks.com/2018/02/mission-accomplishedwhats-next-irans-afghan-fighters-syria/, Erişim tarihi 12.05.2020. 


\section{Tugay'a Eleman Temini}

Her ne kadar İran kendi aracılığı ile Suriye'ye giden Hazaraların Şiiler için kutsal sayılan yerleri korumak için gönüllü olduklarını iddia etse de, Amerika11 Pamela Constable'a göre genç Şii Afganların bu maceraya atılmalarının esas sebebini dini motivasyonlar oluşturmamaktadır. İran tarafından sınırdışı edilmekle tehdit edilen, Fatımiyyun Tugayı'na katılmayı kabul etmeleri halinde ise maddi destek ve oturma izni gibi kolaylıklar vaadi verilen bu gençlerin, hayatlarını tehlikeye atmalarının sebebi daha çok maddi imkanlarını arttırmak olduğu iddialar arasında yer almaktadır. Çünkü Suriye'deki iç savaşta hangi uluslararası aktörün hangi rolü oynadığı ve kimin kimi desteklediği konusunda fazla fikir sahibi olmayan Hazaralar'ın önceliği Tugay'da görev almanın karşıllı̆ında sağlanacak maddi imkanlar ile kendilerinin ve ailelerinin geleceğini kısmen de olsa garanti altına almak gibi durmaktadır. ${ }^{122}$

Daha önce de ifade edildiği üzere, Tugayın ilk kuruluşunda personel sayısı 22 kişi idi. Buna bir süre sonra 15 kişiden oluşan ikinci bir grup ve tekrar 22 kişiden oluşan üçüncü bir grup eklenmişti. Ancak ilk başlarda onlarla ifade edilen milis sayısı bir süre sonra kurulan Beşinci grup da sayı 100'ün üzerine çıtı. Kuruluşundan itibaren geçen 3 yıllık sürede Tugay'ın toplam mevcudu 1.000'i geçmişti. ${ }^{123}$ Milislerin çoğu İran'da göçmen veya sığınmacı statüsünde bulunan Hazaralar' $\mathrm{d}_{1}{ }^{124}$ ve çoğunlukla da Isfahan, Meşhed, Tahran ve Kum şehrinden geliyorlard ${ }^{125}$ Geldikleri yerleri tespit etmek nisbeten kolay olsa da Suriye'deki Afgan Hazaraların tam sayısını tespit etmek zordur. ${ }^{126}$ Ancak bunlardan 700'den fazlasının sadece Şam ve Deraa'daki çatışmalarda öldüğü tahmin edilmektedir. ${ }^{127}$

122 “Tugay'da Suriye'de görev alması için silahaltına alınan milislerin çoğunluğunu mülteci olarak ya da çalışmak için geçici süreyle İran'da bulunanlar ve Iran-Afganistan sınırındaki fakir şehir ve köylerde yaşayanlar oluşturmaktadır." Bkz. Constable, a.g.m.

123 Schneider, a.g.e., s. 5.

124 Smyth, a.g.m.

125 Esfandiari, a.g.m.

126 'Suriye'de çatışmalara katılan Şii Afganların tam sayısını tespit etmek ise neredeyse imkansız, zira Suriye ile Afganistan ve İran arasında sürekli hareket halindeler. Çoğunun aileleri nerede olduklarını bilmiyor. Ayrıca başka bir ülke hesabına savaşmak suç olduğundan, Afganistan'da hapse atılma tehlikesi de onları bekliyor. Bu yüzden Suriye'de çatıştıklarını saklamak zorundalar." Constable, a.g.m.

127 "Fatımiyyun Tugayı'ndaki görev yapan Hazaraların 840 kadarının çatışmalarda hayatlarını kaybettikleri tahmin edilmektedir. Carnegie Endowment'in araştırmasına göre; Şii Afganlar, Lübnan Hizbullahı'nın ardından Suriye'deki çatışmalarda en çok kayıp veren ikinci Iran destekli gruptur. Gözlemcilere göre; Esed güçlerinin özellikle Halep’i geri almasinda Afgan savaşçılar çok kritik roller oynamışlardır.” Constable, a.g.m. 
Zayiatın çok az bir kısmı çatışma hattından alınıp geri getirilmektedir. Geri getirilenlerin cenaze törenleri de yeni milis toplamak için propaganda malzemesi haline getirilmektedir. Ancak bu cenaze törenleri çoğunlukla komutanlara ve önemli kişilere yapılmaktadır. Pek çoğu da iddialara göre öldüğü yerde çürümeye birakılmaktadır. ${ }^{128}$

Grup hakkında fazla bilgi olmadığı için Tugay'ın mevcudu hakkında birbiri ile çelişen görüşler ortaya çıkmaktadır. Bu konuda en çok kabul gören görüş ise Devrim Muhafızları ile iltisaklı Mashreg News'un verdiği 20.000 rakamıdır. Ancak bu rakamın da kaynă̆ının Devrim Muhafizları olması sebebiyle mübalağaya açık olduğu aşikârdır. Ancak bu rakamı makul bulanlar da vardır. ${ }^{129}$ Eski bir Devrim Muhafizları Subayı ve İran Parlamentosu üyesi olan Hüseyin Kenani Moghadem bu sayının 10.000'ler seviyesinde olduğunu iddia etmiştir. Öldürülen Fatımiyyun komutanlarından birisi olan Muhammed Hasan Hüseyni ise 12.00014.000 sayısını vermiştir. ${ }^{130}$

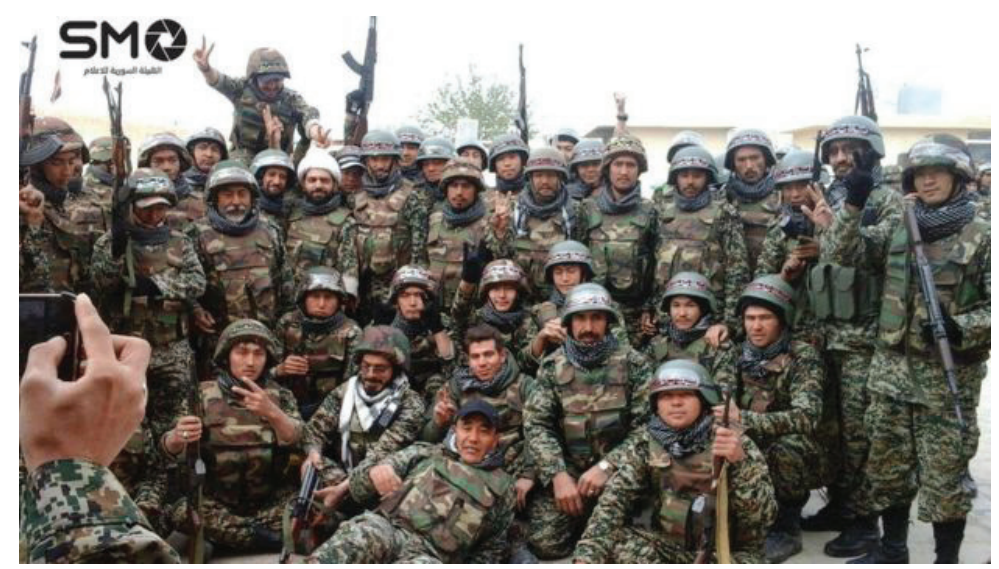

Resim 4. Afgan Şavaşçılar ve İran Devrim Muhafızları. Kaynak: Fariba Sahraei, "Syria War: The Afgans Sent by Iran to Fight for Assad", BBC, 15 Nisan 2016, (https://www. bbc.com/news/world-middle-east-36035095), (Erişim Tarihi: 04.05.2020).

Birlik mevcudu arttığı için 2015 yılında taburdan tugay seviyesine çıkarılmıştı. Bu dönemde İran merkezli Elif Haber Ajansı birlik mevcudunun en az 10.000 olduğunu iddia eden bir haber geçmişti. ${ }^{131} \mathrm{Bu}$ verilen rakamlara daha önce birlikte görev yapanlarla, kültürel ve lojistik görevleri üstelenenler de dâhil edildiğinde

128 Reuter, a.g.m.

129 Moslih, a.g.m.

130 Schneider, a.g.e., s. 5.

131 Schneider, a.g.e., s. 6. 
ulaş1labilir. Muhalifler ise bu sayının bir seferde en fazla 4.000-8.000 arasında olduğunu savunmaktadır. Bu iddialarını da birlikten firar edenlerle çatışmalarda esir alınanlardan alınan bilgilere dayandırmaktadırlar. ${ }^{132}$

Devrim Muhafızları'nın destek unsuru olarak görev yapan bu birliklere milis temini ise başlı başına bir dramdı. Birlikten firar edenler, esir alınanlar, gazeteciler ve diğer görgü tanıklarının ifadelerine göre Afganların askere alınması, eğitimleri ve yaşam şartları ile görev yerleri oldukça zorludur. En zor görevlere gönderilen birlik milisleri çok az eğitim ve ateş desteği verilerek savaş alanına sürülmektedir. ${ }^{133}$ Bunun sonucunda da kayıları ağır olmaktaydı.

İran'da tahminen 3 milyon kadar Afgan göçmen ve sığınmacı olarak bulunmaktadır. ${ }^{134}$ Tugay'ın ana insan kaynağını da bu grup oluşturmaktadır. Tugay’a katılmaya razı olacak olanlara Suriye'de 6 aydan daha fazla kalmaları halinde ailelerine İran'da kalıcı oturma izni verileceği vaat edilmekte idi. ${ }^{135}$ İktisadi durumu yıllardır süren ekonomik yaptırımlar ve uluslararası ambargo nedeniyle hayli sıkıntılı olan İran'da geçim sıkıntısı çeken, göçmen olmaları sebebiyle bürokratik ayrımcılığa ve yabancı düşmanlığına maruz kalan Afgan mültecilerin hemen hepsi Afganistan'a geri gönderilmekten korkmaktadırlar. ${ }^{136}$ Görünen o ki, İran'da bu korkuyu gayet iyi kullanmaktadır. İran'daki Hazaralar sürekli bir s1-

132 “Muhaliflerce esir alınan Fatimiyyun Tugayı üyelerinden birisi olan ve Human Rights Watch'a konuşan Hamid Ali isimli Afgan, Tugay'in Halep, Hama, Humus, Lazkiye ve Şam'da bulunan üslerinde toplam 3.000-4.000 kadar milis olduğunu belirtmiştir. Ali'nin ifadesine göre her sektörde ortalama 400 kadar milis bulunmaktadır. Bu bilgi Tugay'ın propaganda filmlerindeki görüntülerle de uyuşmaktadır. Bu görsellerde genellikle her biri 200-250 kişiden oluşan 2 Birlik görülmektedir.” Bkz. Schneider, a.g.e., s. 6. Ayrıca bkz. Sune Engel Rasmussen - Zahra Nader, "Iran Covertly Recruits Afghan Shias to Fight in Syria," The Guardian, 30 Haziran 2016, https://www.theguardian.com/world/2016/jun/30/iran-covertly-recruits-afghan-soldiers-to-fight-in-syria , Erişim tarihi 12.05.2020.

133 Farzam - Sarı, a.g.m., s. 273. Ayrica bkz. Fariba Sahraei, "Syria War: The Afgans Sent by Iran to Fight for Assad", $B B C, 15$ Nisan 2016, https://www.bbc.com/news/world-middleeast-36035095, Erişim tarihi 12.05.2020.

134 İran'da yaşayan Hazarlar'a "Berberi” denilmektedir. (M.E.K.)

"İran İçişleri Bakanlı̆̆ı'nın 2015 yılı verilerine göre ülkede çoğunun oturma izni olmayan 2.5 Milyon Afgan yaşıyor.” Gamze Türkoğlu Oğuz, "HRW: İran, Suriye'de Afgan Göçmen Çocukları Savaştırıyor", Anadolu Ajansı, 1 Ekim 2017, https://www.aa.com.tr/tr/dunya/hrw-iran-suriyede-afgan-gocmen-cocuklarini-savastiriyor/924166, Erişim tarihi 14.06.2020.

135 Neriah, a.g.m.

136 Patrick Strickland, "Why Are Afghan Refugees Leaving Iran?”, Al Jazeera, 17 May1s 2016, https://www.aljazeera.com/indepth/features/2016/05/afghan-refugees-leaving-iran-160511103759873.html, Erişim tarihi 14.06.2020. 
nırdışı edilme korkusu ile yaşamakta ${ }^{137}$ ve geçimlerini sağlamak için de inşaat işçiliği, hizmetçilik, seyyar satıcılık gibi işlerde çalışmaktadırlar. ${ }^{138}$ Bu yüzden de son yıllarda Avrupa'ya giden göçmen akınında Afgan Hazaralar, Suriyeli'lerden sonra hatrı sayılır bir oranı oluşturmaktadır. ${ }^{139}$

Bu konularda uluslararası basın kuruluşlarına konuşan bazı eski milisler İran güvenlik güçleri tarafından kaçak yollardan ülkeye girmekle veya uyuşturucu kaçakçılığı suçlaması ile tutuklandıklarını sonrasında ise kendilerinden hapse girme, Afganistan'a sınırdışı edilme veya Suriye'de İran için savaşma seçeneklerinden birini tercih etmelerinin istendiğini aktarmışlardır. ${ }^{140}$

$\mathrm{Bu}$ eski milislerin aktardıklarına göre Tugay üyelerine aylık 450-800 Dolar arasında değişen bir ödeme yapılmaktadır. ${ }^{141}$ Bu rakam pek çok Afganlı için küçük bir servet değerindedir. ${ }^{142}$ Ancak vaat edilenin aksine gerek maaş ödemeleri

137 Mehdi Jedinia ve Noor Zahid, "Iran Continues Deporting Undocumented Afghan Refugees", Voice of America, 21 May1s 2017, https://www.voanews.com/extremism-watch/iran-continues-deporting-undocumented-afghan-refugees , Erişim tarihi 14.06.2020.

138 Bkz. Schneider, a.g.e., s. 7.

139 Peter Bouckaert, “Europe's Refugee Crisis Isn't Only About Syria”, Foreign Policy, 18 Ekim 2015, https://foreignpolicy.com/2015/09/18/europes-refugee-crisis-isnt-only-about-syria-iraqafghans/, Erişim tarihi 14.06.2020.

140 Ali M. Latifi, "How Iran Recruited Afghan Refugees to Fight Assad's War," The New York Times, 30 Haziran 2017, https://www.nytimes.com/2017/06/30/opinion/sunday/iran-afghanistan-refugees-assad-syria.html, Erişim tarihi 14.06.2020.

"Iran Sending Thousands of Afghans to Fight in Syria," Human Rights Watch, 29 Ocak 2016, https://www.hrw.org/news/2016/01/29/iran-sending-thousands-afghans-fight-syria, Erişim tarihi 14.06.2020.

"Suriye'de para karşılığında üç ay rejim safinda savaştıktan sonra sağ olarak geri dönen bir Afgan göçmeni olan Abbas'a göre Iran'a iltica ederken tutuklanan Afgan göçmenler Suriye'de savaşmaya zorlanmaktadır.” Farzam - Sarı, a.g.m., s. 273.

141 “22 Mayls 2014 'te Wall Street Journal, Iran Devrim Muhafizları'nın Suriye'de savaştırılmak üzere Afgan Şiileri askere aldĭ̆ını aktarmıştır. Bu hizmetleri karşılığında Afganlara aylık 500 Dolar maaş ve Iran'da oturma izni verileceğinin vaat edildiği aktarılmaktadır." Smyth, a.g.m.

142 "Afganistanın Uluslararası Para Fonu (IMF) Satın Alma Paritesine göre ortalama kişi başına ylllı geliri 2010 verilerine göre \$ 907 dolardır ve ülke dünya genelindeki gelir sıralamasında Mozambik ve Madagaskar'ın ardından 173. sırada bulunmaktadır." Bkz. "Ülkelerin Kişi Başına Düşen Milli Gelirleri”, Sabah, 19/04/2011, https://www.sabah.com.tr/galeri/ekonomi/ ulkelerin-kisi-basina-dusen-milli-gelirleri, Erişim tarihi 15.07.2020.

Bu rakamlar takip eden yıllarda iyileşmek yerine daha da gerilemiştir. Ülke 2017 yılı Birleşmiş Milletler rakamlarına göre Kişi Başına Düşen GSYİH sıralamasına göre 619 Dolarla 181. sırada idi. Takip eden yılda ise bu rakam ve sıralama IMF verilerine göre 544 Dolarla 177. sıra olmuştur. Dünya Bankası rakamlarına göre ise bu sıralama 521 Dolarla 174. sıra olarak gerçekleşmiştir. Daha fazla billgi için bkz. "Kişi Başına Nominal GSYİH Değerlerine Göre 
gerekse de İran'da oturma izni konularında sıkıntıların yaşandığı ifade edilmektedir. Türkiye üzerinden Midilli'ye kaçan ve orada yakalanan bir göçmen sorgusunda Suriye'de 12 ay savaştı̆̆ını ancak İran'a geri döndügü zaman kendisine 30 günlük bir oturma izninin verildiğini ifade etmiştir. Bu durumdan hayal kırıklığına uğradığ 1 için Avrupa'ya gitmeye karar verdiğini söylemiştir. ${ }^{143}$

Suriye İç Savaşı'nı konu alan bir Human Rights Watch $(H R W)$ Raporunda ise yaşları 14-17 arasında değişen ve Suriye'deki çatışmalarda ölen 14 Afganlı çocuğunun bilgilerine ulaşıldığını açıklanmıştır. ${ }^{144}$ İran Yönetimi de Batı Dünyası'nın kendisini bu konu üzerinden sıkıştırmasının önünü almak için kaçak göçmenlerin sığınma hakkı alabilmek için yalan beyanlarda bulunup, hikâyeler uydurduklarını iddia etmektedir. Ancak bu çocuk askerlerin mezarları Tahran'daki Beheşt-i Zehra Mezarlığı'nda bulunmaktadır ve Uluslararası Hukuk kapsamında 15 yaşındaki çocukların askere alınması ve savaştırılması savaş suçu sayılmaktadır. ${ }^{145}$

Ülkeler Listesi”, Vikipedia, https://tr.wikipedia.org/wiki/Ki\%C5\%9Fi_ba\%C5\%9F\%C4\%B1na_nominal_GSY\%C4\%B0H_de\%C4\%9Ferlerine_g\%C3\%B6re_\%C3\%BClkeler_listesi, Erişim tarihi 15.07.2020.

“Dünyanın 173. ekonomisi Afganistan'ın gayri safi yurt içi hasılası 2015 tahminlerine göre 19,2 milyar dolar. Ülkede kişi başına gelir 590,27 dolar civarında, ihracat 865 milyon, ithalat 7,63 milyar dolar seviyesinde. Afganistan'da enflasyon 2016 yılında yüzde 5,9, işsizlik oranı yüzde 40 çıktı.”, “Afganistan”, Anadolu Ajansı, Ülke Profilleri, 05/09/2017, https://www. aa.com.tr/tr/ulke-profilleri/afganistan/901494, Erişim tarihi 15.07.2020.

143 Bkz. Schneider, a.g.e., s. 7.

144 Lara Seligman, “The Child Soldier Crisis: 'Kids Are Cheap”, Foreign Policy, Report, 8 Kasım 2019, https://foreignpolicy.com/2019/11/08/child-soldier-crisis-kids-are-cheap-yemen-isis-my-star-sky/, Erişim tarihi 15.07.2020.

Nada Homsi, "Afghan Teenagers Recruited in Iran to Fight in Syria, Group Says", The New York Times, 1 Ekim 2017, https:/www.nytimes.com/2017/10/01/world/middleeast/iran-afghan-child-soldiers-syria-war.html, Erişim tarihi 15.07.2020.

"Iran: Afghan Children Recruited to Fight in Syria", Human Rights Watch, 1 Ekim 2017, https://www.hrw.org/news/2017/10/01/iran-afghan-children-recruited-fight-syria, Erişim tarihi 15.07.2020.

Naomi Conrad, "Iran recruits Afghan teenagers to fight war in Syria", Deutsche Welle, 5 May1s 2018, https:/www.dw.com/en/iran-recruits-afghan-teenagers-to-fight-war-in-syria/a-43634279, Erişim tarihi 15.07.2020.

145 'HRW uzmanlarının, Suriye'de hayatını kaybeden ve Iran'da defnedilenlerin mezar taşlartnın fotoğraflarını incelediği, Suriye'de savaşta yaşamın yitirmiş 8 Afgan çocuğun kimliğini tespit ettiği belirtildi. Tahran'daki Beheşti Zehra Mezarlığında şehitlik bölümüne gömülen 5 çocuğun 14 yaşında olduğu, İsfahan ve yine Tahran'da Elburz'da 2'si 17, biri 15 yaşındayken hayatını kaybeden çocukların belgelendiği kaydedildi. Iran yerel basınının da Suriye'de 'şehit düşen' Fatimiyyun üyesi çocukların cenaze törenlerini haberini yaptığl, en az 6 benzer vakayı daha gün ışığına çıkardı̆̆ı bildirildi.” Oğuz, a.g.m. 


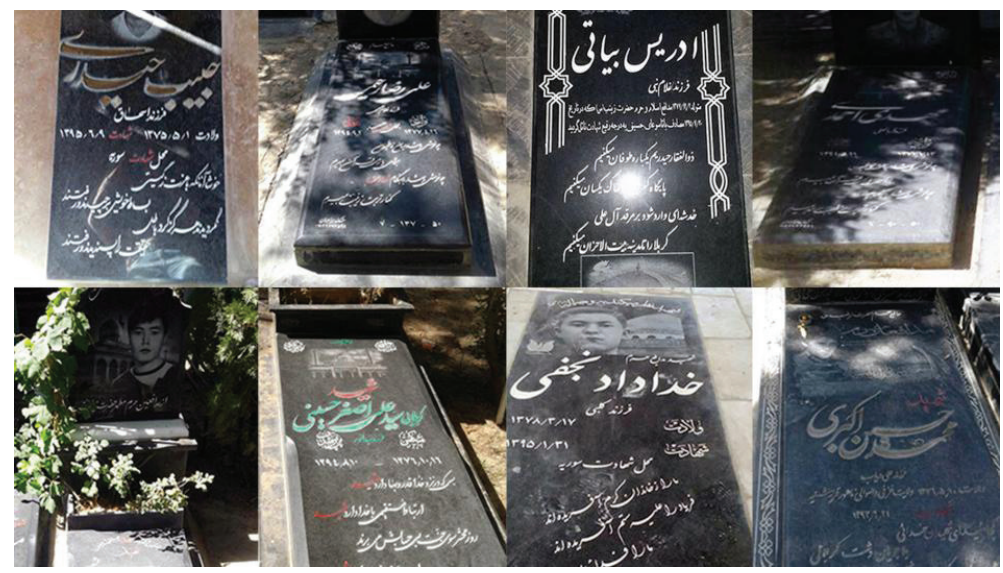

Resim 5. İran'da Gömülen Afgan Çocuk Askerlerin Mezarları. Kaynak: "Iran: Afghan

Children Recruited to Fight in Syria”, Human Rights Watch, 1 Ekim 2017”, (https://www.hrw.org/news/2017/10/01/iran-afghan-children-recruited-fight-syria),

(Erişim Tarihi: 27.04.2020).

Tablo 1. Teyitli Çocuk Asker Kayıpları

\begin{tabular}{|l|l|l|l|l|l|l|}
\hline $\begin{array}{l}\text { Mezartaşında } \\
\text { Yazan İsim }\end{array}$ & $\begin{array}{l}\text { Doğum } \\
\text { Yeri }\end{array}$ & Doğum tarihi & Ölüm tarihi & $\begin{array}{l}\text { Ölüm } \\
\text { Yeri }\end{array}$ & Defin Yeri & Yaşı \\
\hline $\begin{array}{l}\text { Ali Rıza } \\
\text { Rahimi }\end{array}$ & - & 17 Temmuz 1998 & 23 Kasım 2015 & $\begin{array}{l}\text { Halep } \\
\text { Suriye }\end{array}$ & $\begin{array}{l}\text { Tahran } \\
\text { Behesht- } \\
\text { e-Zahra } \\
\text { Mezarlığ1 }\end{array}$ & 16 \\
\hline $\begin{array}{l}\text { Muhammed } \\
\text { Hüseyin Akbari }\end{array}$ & $\begin{array}{l}\text { Gazne } \\
\text { Vilayeti } \\
\text { Afganistan }\end{array}$ & 31 Temmuz 2000 & 12 Eylül 2014 & - & $\begin{array}{l}\text { Tahran } \\
\text { Behesht- } \\
\text { e-Zahra } \\
\text { Mezarlığ1 }\end{array}$ & 14 \\
\hline $\begin{array}{l}\text { Mehdi Ahmedi } \\
\text { Ramazan } \\
\text { Mirzai }\end{array}$ & 5 Ekim 1998 & $\begin{array}{l}12 \text { Ağustos } \\
2015\end{array}$ & $\begin{array}{l}\text { Tahran } \\
\text { Behesht- } \\
\text { e-Zahra } \\
\text { Mezarlığ1 }\end{array}$ & 16 \\
\hline
\end{tabular}




\begin{tabular}{|l|l|l|l|l|l|l|}
\hline $\begin{array}{l}\text { Seyid Ali Asker } \\
\text { Hüseyni }\end{array}$ & 6 Ocak 1998 & 1 Kasım 2015 & & $\begin{array}{l}\text { Tahran } \\
\text { Behesht- } \\
\text { e-Zahra } \\
\text { Mezarlığ }\end{array}$ & 17 \\
\hline $\begin{array}{l}\text { Nur } \\
\text { Muhammed } \\
\text { Davudi }\end{array}$ & 22 Mayıs 2000 & 4 Aralı 2015 & $\begin{array}{l}\text { Palmira } \\
\text { Suriye }\end{array}$ & $\begin{array}{l}\text { Pakdeşt } \\
\text { Mezarlığ } \\
\text { Tehran } \\
\text { Vilayeti }\end{array}$ & 15 \\
\hline $\begin{array}{l}\text { Hudadad } \\
\text { Necefi }\end{array}$ & 7 Haziran 1999 & 19 Nisan 2016 & Suriye & $\begin{array}{l}\text { Sovojbolagh } \\
\text { Elburz } \\
\text { Vilayeti }\end{array}$ & 16 \\
\hline İdris Bayati & & 21 Şubat 1999 & 11 Ekim 2016 & & $\begin{array}{l}\text { Najaf Abad } \\
\text { Isfahan } \\
\text { Vilayeti }\end{array}$ & 17 \\
\hline
\end{tabular}

Tablo 2. Yazılı Basında İsmi Geçen Çocuk Asker Zayiatları

\begin{tabular}{|c|c|c|c|c|c|c|}
\hline $\begin{array}{l}\text { Mezartaşında } \\
\text { Yazan İsim }\end{array}$ & $\begin{array}{l}\text { Doğum } \\
\text { Yeri }\end{array}$ & Doğum tarihi & Ölüm tarihi & Ölüm Yeri & Defin Yeri & Yaşı \\
\hline Habib Haydari & & 22 Temmuz 1996 & 30 Ağustos 2016 & $\begin{array}{l}\text { Halep, } \\
\text { Suriye }\end{array}$ & $\begin{array}{l}\text { Sovojbolagh } \\
\text { Elburz } \\
\text { Vilayeti }\end{array}$ & 17 \\
\hline $\begin{array}{l}\text { Muhammed } \\
\text { Kalantari }\end{array}$ & & & 11 Eylül 2014 & & & 16 \\
\hline $\begin{array}{l}\text { Muhammed } \\
\text { Resul } \\
\text { Haydari }\end{array}$ & & & & & $\begin{array}{l}\text { Bumehen, } \\
\text { Tehran } \\
\text { Vilayeti }\end{array}$ & 17 \\
\hline Ahmed Turabi & & 20 Mart 1996 & 11 Kasım 2013 & Suriye & Isfahan & 16 \\
\hline Hasan Rahimi & Kum & $\begin{array}{l}1995 \text { (Nakledilen } \\
\text { Doğum Tarihi ise } \\
23 \text { Aralık 1999) }\end{array}$ & 24 Aralık 2015 & Suriye & & 16 \\
\hline $\begin{array}{l}\text { Muhammed } \\
\text { Zaman Atayi }\end{array}$ & & 1993 & 12 Ekim 2015 & & Şiraz & 17 \\
\hline
\end{tabular}

Kaynak: "Iran: Afghan Children Recruited to Fight in Syria", Human Rights Watch, 1 Ekim 2017", (https://www.hrw.org/news/2017/10/01/iran-afghan-children-recruited-fight-syria), (Erişim Tarihi: 27.04.2020). 


\section{Askeri Eğitim ve Donatım}

Afganistan'ın Kabil ve Herat gibi büyük şehirlerinde açılan isimsiz bürolar vasıtası ile Afganlar para karşılığında Suriye'de savaşmak üzere istihdam edilmektedir. ${ }^{146}$ Tugay'a yeni katılan milisler 2-4 hafta arasında değişen bir temel eğitime tabi tutulmakta, ${ }^{147}$ bu esnada temel piyade eğitimi almaktadırlar. Bu eğitim İran'daki 9 farklı kampta Devrim Muhafızları tarafından verilmektedir. Bu kamplardan bilinenlerden biri Tahran dışındaki Karçak’taki Padegan-1 Şehid Pazuki, diğer ikisi Şiraz ve Yezd yakınlarındadır. Batı İstihbarat örgütleri tarafından sağlanan belgelerde kamplarda Afganlar'ın yanında Pakistanlılar ve Araplar'ın da olduğu görülmektedir, ancak sayıları birkaç yüzü geçmemektedir. ${ }^{148}$ Ayrıca bu birliklerin Suriye'deki kamplarda da eğitim aldığ ifade edilmektedir.

Tugay çok çeşitli türde ve çapta topçu silahı ve tank kullanmaktadır. İran Devrim Muhafızları ile Suriye Ordusu arasında yapılan anlaşma gereği, İran'ın ve ona tabi güçlerin Suriye Ordusu'nun ikmal ve levazım depolarına sınırsız ve sorunsuz bir erişimi vardır. ${ }^{149}$ Suriye Ordusu firarlar nedeniyle oldukça güçten düşmüştür, bu yüzden de eldeki teçhizatı kullanacak asker bulmada sıkıntı yaşamaktadır. Rusya Federasyonu Ordusu ve İran Devrim Muhafızları ve Fatımiyyun Tugayı gibi onun bağlılarından bu yüzden medet ummaktadır. Bunun sonucunda atıl halde duran ve geniş bir yelpazesi olan eski Sovyet dönemi silahları Tugay tarafından kullanılmaktadır. ${ }^{150} \mathrm{Bu}$ silahlara T-90 tankları da dâhildir. Afgan asıllı araştırmacı Ahmet Şuca'ya göre Ruslar tarafından BMP zırhlı piyade savaş aracı kullanımı konusunda da Afganlara eğitim verilmektedir. ${ }^{151}$

146 Farzam - Sar1, a.g.m. , s. 273.

147 “Tugay'a yeni katılan milis adayları Iran'ın çeşitli şehirlerinde bulunan eğitim merkezlerinde 25-35 günlük bir eğitim süresinden sonra Suriye’ye gönderilmektedir." Scott Peterson, "Iran Steps up Recruitment of Shiite Mercenaries for Syrian War", The Chiristian Science Monitor, 12 Haziran 2016, https://www.csmonitor.com/World/Middle-East/2016/0612/Iran-steps-up-recruitment-of-Shiite-mercenaries-for-Syrian-war, Erişim tarihi 15.07.2020.

148 Schneider, a.g.e., s. 9.

149 Schneider, a.g.e., s. 10.

150 Schneider, a.g.e., s. 10.

151 "Russia Trains Iran-sponsored Shia Militias in Syria", Afghanistan Analysis, 1 Aralık 2017, https://afghanistananalysis.wordpress.com/2017/12/01/russia-trains-iran-sponsored-shia-militias-in-syria/, Erişim tarihi 15.07.2020. 
Ancak silah ve teçhizata rahat erişim imkânlarına rağmen, Tugay'da savaşmış olan eski milislerin ifadelerine göre İranlılar tarafından silah altına alınan Afganlar harcanabilir olarak görüldükleri için çatışmaya psikolojik ve fiziki olarak çok az hazırlanmaktadır. ${ }^{152} \mathrm{Bu}$ yüzden Afgan Hazaralar Suriye İç Savaşı'nda çatışan gruplar arasında zayiat oranları sürekli olarak artan tek gruptur. Devrim Muhafızları'nın idaresinde savaşan Iraklı ve Lübnanlı Şii milis grupları da bulunmaktadır ancak onların sevk ve idaresinde böyle bir olumsuzluk bildirilmemektedir. Yapılan cenaze törenlerinden derlenen data, kayıpların sürekli olarak arttığını teyit etmektedir. Öyle ki, bu zayiat rakamları Halep Muharebesi ${ }^{153}$ ve DAEŞ'e karşı girişilen çarpışmalarda ayda 45' in üzerine çıkmıştır. ${ }^{154}$ Sonuç olarak; Afgan Hazaraları Suriye'de Devrim Muhafızları ve ona bağlı diğer grupların kayıplarını telafi etmek ve onların yerine zayiat vermeleri için toplanmışlardır. ${ }^{155}$ Suriye'ye intikalinden itibaren grup İranlılar tarafından hemen her cephede en ön safta savaştırılmıştır. (Lazkiye, Şam, İdlip, Hama, Humus, Deraa, Deyrizor) Gerek kültür gerekse de dil açısından izole edilmiş bir halde bulunan Afgan Hazaralar, girdikleri muharebelerde kendilerine yeterli bilgi verilmeden çatışmaya sokulmuş, Suriye Ordusu'nun yolsuzluk veya firarlar sebebiyle tutamadığı bölgelerde savaşmaya gönderilmiştir. Yabancı olmaları ve harcanabilir olarak görülmeleri her yere gönderilmelerini kolaylaştırmaktadır.

152 "Tahran yönetimi ise, kendi güçlerinden kayıp vermemek adına İranlı olmayan kişileri Suriye'deki çatı̧̧malara sürdüğ̈̈ yolundaki iddiaları reddetmektedir.” Constable, a.g.m.

153 Louisa Loveluck, "The Battle for Aleppo, Explained”, The Washington Post, 24 Kasim 2016, https://www.washingtonpost.com/news/worldviews/wp/2016/11/24/the-battle-for-aleppo-explained/, Erişim tarihi 15.07.2020.

Robin Wright, "The Battle For Aleppo, Syria's Stalingrad, Ends", The New Yorker, 13 Aralik 2016, https://www.newyorker.com/news/news-desk/the-battle-for-aleppo-syrias-stalingrad-ends, Erişim tarihi 15.07.2020.

154 Schneider, a.g.e., s. 11.

155 Smyth, a.g.m. 


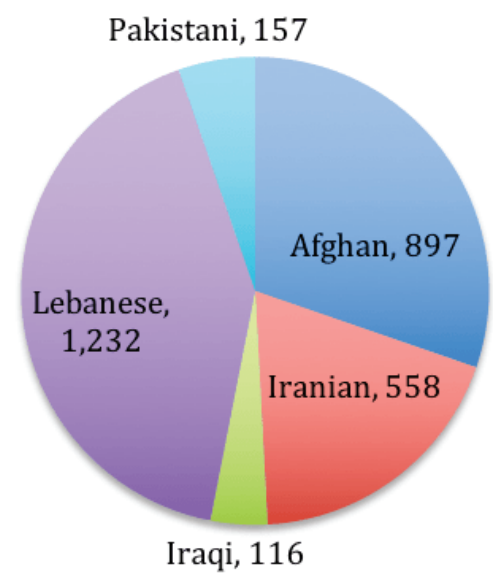

Resim 6. 2012 Ocak-2018 Temmuz Arasında Suriye'de Öldürülen Şii Yabancı Savaşçılar. Kaynak: Ali Alfoneh, Four Decades in the Making: Shia Afghan Fatemiyoun Division of the Revolutionary Guards, The Arab Gulf States Institute in Washington, 25 Aralik 2018, (https://agsiw.org/four-decades-in-the-making-shia-afghan-fatemiyoun-division-of-the-revolutionary-guards/), (Erişim Tarihi: 28.04.2020).

\section{Afganistan'a Dönüş}

Suriye'de çarpışan bu milislerin bir kısmı kendilerine vaat edilenlerin verilmemesi sebebiyle geri dönmek zorunda kalmaktadır. Ancak bu eski milislerle Hazara toplumunun ilişkisi oldukça tartışmalı bir konudur. Afgan Hükümeti bu grubu yasadışı ilan etmiştir. Gruba asker temin ettiği düşünülen kişiler ki aralarında İran'ın dini liderinin Kabil temsilcisi Kurban Galambor da vardır, Afgan yetkilileri tarafindan tutuklanmıştır. ${ }^{156}$ Bunun üzerine Devrim Muhafizları tarafından yürütülen bu personel tedarikleri yeraltına inmiştir. ${ }^{157}$ Hem Kabil hem de Herat'ta Fatimiyyun askere alma büroları bulunduğu ifade edilmektedir. ${ }^{158}$ Aynı faaliyetin Pakistan'ın batı sınırı boyunca yapıldığı da iddialar arasındadır. Burada da Fatımiyyun Tugayı'nın kardeş birliği Zeynebiyyun Tugayı'na eleman temini yapılmaktadır.

156 Ahmad Majidyar, "Afghan Officials in Deep Water After Praising Role of Soleimani and Shiite Militias in Syria”, Middle East Institute, 29 Kasim 2017, https:/www.mei.edu/publications/ afghan-official-deep-water-after-praising-role-soleimani-and-shiite-militias-syria, Erişim tarihi 15.07.2020.

157 “Ancak halen Kabil'deki Iran Büyükelçiliği tarafindan koordine edildiği iddia edilmektedir". Bkz. Tom Coghlan, Aimal Yaqubi - Sara Elizabeth Williams, "Assad Recruits Afghan Mercenaries to Fight Isis," The Times, 2 Haziran 2015, https://www.thetimes.co.uk/article/assad-recruits-afghan-mercenaries-to-fight-isis-rzvp3bh2fhh, Erişim tarihi 15.07.2020.

158 Peterson, a.g.m. 
Afganistan'da süren faaliyeti ile ilgili korkulan şey İran'ın Rusya'nın da desteği ile Afganistan'daki Batı destekli Uzlaşma Hükümeti'ni yıkmak için Suriye'de savaşmış olan bu milisleri yeniden organize ederek Afganistan'a taşıma ihtimalidir. ${ }^{159}$ Tanınmış Afganistan uzmanlarından birisi olan Antonio Guistozzi'ye göre ülkede 4.000'den fazla üyesi olan ve başlarında Suriye'den dönen deneyimli milislerin olduğu bir Şii Hazara grubu yapılanması vardır. İran Devrim Muhafızları'nın mali açıdan destek olduğu bu grup Hazaracat, Kabil ve Mezar-1 Şerif'te bir hayli faaldir. Guistozzi, grubun hâlihazırda Vardak Vilayeti'nde Hazara ve İran karşıtı gruplara karşı sınırlı da olsa silahlı çatışmaya girdiklerini ifade etmektedir. ${ }^{160}$ Ancak Afganistan'a dönenlerin bir kısmı yine ekonomik ve diğer sebepler nedeniyle Suriye'ye gönderilmek için tekrar birliğe katılmak zorunda kalmaktadır. ${ }^{161}$

Suriye İç Savaşı'na Hazaralar'ın İran safında katıldığının Afganistan'da duyulması ülkedeki istikrarsızlığı daha da arttırmaktadır. Afganistan sınırının her iki tarafinda yer alan radikal gruplar Suriye ve Irak'ta İran'ın faaliyetlerine destek oldukları için intikam alma amacıyla Hazaralar'a saldırmaktadır. Bu saldırılardan birisi 2016 yılında Kabil'de 80 Hazara'nın ölümü ile sonuçlanan saldırıdır. Bir diğer saldırı ise yine Kabil’de 2017 yılında Şii Tabayan Kültür Merkezi’ne yapılan intihar saldırısıdır. Bu saldırıda da en az 40 kişi ölmüştür. ${ }^{162}$

159 Bu ihtimalle ilgili bkz. Hüda Hüseyni, 'Fatımiyyun' Tugayı ABD ile Yüzleşmek için Suriyeyi Terk Ediyor”, Şarkul Avsat, 6 Haziran 2019, https://aawsat.com/turkish/home/article $/ 1755586 / \mathrm{h} \% \mathrm{C} 3 \% \mathrm{BCda}-$ huseyni/\%E2\%80\%98fat $\% \mathrm{C} 4 \% \mathrm{~B} 1$ miyyun $\% \mathrm{E} 2 \% 80 \% 99$-tugay $\%$ C4\%B1-abd-ile-\%C3\%BCzle\%C5\%9Fmek-i\%C3\%A7in-suriye \%E2\%80\%99yi-terk-ediyor, Erişim tarihi 15.07.2020.

160 Schneider, a.g.e., s. 12.

161 “Oxfam raporuna göre, Afganistan'da her 30 dakikada doğumla ilişkili komplikasyonlar nedeniyle bir kadın ölürken, aynı süre içinde bir başka kadın da veremden hayatını kaybediyor. Ingiliz Çocukları Koruyun derneğine göre ise, her iki dakikada bir çocuğun öldüğü Afganistan, dünyaya gelmek için en kötü ülke. Dünya Bankası'nın düzenlediği bir anket de Afganistan nüfusunun yüzde 36 'sın oluşturan 9 milyon insan açlık sınırının altında yaşadığın ortaya koydu. ", "Yoksulluğun Maliyeti 40 Milyar Dolar", Hürriyet, 21 Temmuz 2010, https:// www.hurriyet.com.tr/gundem/yoksullugun-maliyeti-40-milyar-dolar-15361941, Erişim tarihi 15.07.2020.

162 Thomas Joscelyn, “Islamic State's Khorasan 'Province' Claims Responsibility for Attack on Cultural Center in Kabul," FDD's Long War Journal, 28 Aralık 2017, https://www. longwarjournal.org/archives/2017/12/islamic-states-khorasan-province-claims-responsibility-for-attack-on-cultural-center-in-kabul.php, Erişim tarihi 13.03.2020. 


\section{Sonuç}

Korumaya yemin ettikleri türbeden yüzlerce kilometre uzaktaki cephe hatlarının en ön saflarına gönderilen Fatımiyyun Tugayı, Suriye'de İran Devrim Muhafızları'nın komutasındaki Iraklı, Suriyeli, Lübnanlı, Pakistanlı Şii milislerden oluşan çok uluslu gücün bir parçası olarak Şam'dan Irak sınırına kadar olan bölgede hemen her yerde savaştırıldı ve İran'ın Irak üzerinden Suriye ve Lübnan ile kurmaya çalıştığı kara bağlantısının tesisine yardımcı oldu.

Söz konusu milis güçler üzerinden Suriye İç Savaşı'na dâhil olan İran, doğrudan kayıpları en aza indirmeye çalışmıştır. Çünkü Suriye' de ayaklanmaların ilk çıktığı Mart 2011'den beri Esed rejimine aktif olarak askeri destek veren İran bu desteği sırasında önemli askeri kayıplar vermiştir. ${ }^{163}$ Bunun üzerine strateji değişikliğine giden Tahran yönetimi, İran'daki Afgan sığınmacıları çeşitli vaatlerle Suriye'de rejim yanında savaşmaları için örgütlemeye başlamıştır. Bu sayede doğrudan askeri kayıplarını en aza indirmiştir.

Ek olarak savaşın kendisine olan maliyetini de düşürerek İran ekonomisi üzerindeki yıkıcı etkisinden korunmaya çalışılmış, Suriye İç Savaşı'na doğrudan müdahil olmadığını iddia ederek uluslararası kamuoyu ve uluslararası hukukun bask1 ve yaptırımlarından kurtulmuştur. Kendini dünya Şiilerinin tek hamisi olarak gören İran, Afganistan, Bahreyn, Birleşik Arap Emirlikleri, Suudi Arabistan, Kuveyt, Katar, Lübnan, Irak ve Suriye Şiilerini kapsayan paramiliter bir koalisyona liderlik etmektedir. İran bu paramiliter aktörler aracılığıyla kendi ideolojik ve kültürel nüfuz alanını genişleterek bölgede etkinliğini artırmaya çalışmaktadır. ${ }^{164}$ İran ayrıca yıllardır çok sayıda Afgan sığınmacıya ev sahipliği yapmaktadır. Gerek bu zorunlu evsahipliği gerekse de uluslararası ambargo nedeniyle ülke ekonomisi zorlanmakta, sığınmacılar da zorlanan ekonomiye ek bir yük bindirmektedir. Afgan Hazaralar'in zorla Suriye'de savaşmaya gönderilmesi ile hem ekonomiye getirdikleri yük ve oluşturdukları iç güvenlik riski en aza indirilmekte ve hem de dünya kamuoyuna onların hamisinin İran olduğu mesajı verilmektedir. Bu noktada Türkiye'nin cumhuriyet döneminin ilk yıllarında olduğu gibi yeniden Afganistan'da ve hatta Farisi kökenli oldukları iddiası bir kenara bırakılarak Tacikistan'da insiyatif alması gerekmektedir. Bu girişimlerin ülkenin yumuşak gücü

163 “Şubat 2013 'te muhalifler tarafindan öldürülen Tümgeneral Hasan Şatiri Iran'in verdiği ilk büyük askeri kayıp olarak tarihe geçerken, Kasım 2015 'te Tümgeneral Hüseyin Hamedani ve Mart 2016'de de Tuğgeneral Hasan Ali Şemsabadi Suriye Savaşı'nda hayatını kaybeden diğer büyük askeri yetkililer olmuşlardır. Ocak 2012'den Mart 2016'ya kadar 350 civarında Iranlı askerin Suriye Iç̧ Savaşı'nda öldürüldüğ̈̈ tahmin edilmektedir." Bkz. Ünal, a.g.m., s. 4.

164 Benzer görüş için bkz. Farzam - Sarı, a.g.m., s. 285-286. 
ve kültürel diplomasideki etkinliğini arttıracağı açıktır. Yoksa yukarıda anlatılan sürecin de gösterdiği gibi tamamen sahipsiz ve desteksiz olarak görülen bu topluluklar suistimal edilmekte, hatta Türkiye'ye karşı da kullanılabilmektedir.

Afganistan ve İran'da baskı altındaki yaşamlarının kendilerini zorlamasının İran tarafından bir firsat olarak kullanılması sebebiyle Suriye'ye İran adına savaşmaya gönderilip orada ölmeye devam etseler de, İran'1n Irak-Suriye-Lübnan koridorunu gerçekleştirdiği için Fatımiyyun Tugayı'nın devam etmesi için gereken en önemli sebep kısa vadede ortadan kalkmaktadır. Ancak bu durumun sürekli olup olmayacağı konusu henüz kesinleşmemiştir. İran ve Rusya Federasyonu'nun desteği sayesinde Esed Rejimi iktidarını korumayı başarmış ve ülke genelinde hâkimiyetini yeniden kurmaya başlamıştır. İran, Suriye'deki askeri-ideolojik kazançlarını kendince garantilediğini düşünmektedir. Bu sebeple de ülkedeki kazanımlarını ideolojik ve siyasi sermayeye çevirmeye ve Rusya Federasyonu ile savaş sonrasında kurulacak paylaşım masası için elini kuvvetlendirmeye çalışmaktadır. Kendilerine duyulan ihtiyaç azaldığ 1 için eleman alı$\mathrm{m} 1$ bir süre için durdurulmuş olan Tugay'a Suriye'de 2020 y1lı itibarıyla ortaya çıkan yeni durum sebebiyle yeniden ihtiyaç duyulabilir. Bu da Hazaralar'ın İran tarafından suistimal edilmesinin bir süre daha sürebileceği anlamına gelmektedir. Hazara Fatımiyyun Tugayı'nın kuruluş süreci ile Devrim Muhafızları organizasyon kabiliyetini arttırmıştır. 3 yıl içinde neredeyse sıfırdan oluşturulan bu milis gücü ile elde edilen tecrübenin İran tarafından gerekli görülen yerlerde kullanılacağı açıktır. ${ }^{165} \mathrm{Bu}$ da Afganistan'ın ve Orta Asya'yı içine alan tarihi Horasan Bölgesi'nin daha iyi takip edilmesi ve boş bırakılmaması gerektiğini göstermektedir. Bu kapsamda Hazaralar'la da ilgilenilmelidir çünkü Afganistan'ın bu insanlardan elde edilecek bilgilerin Türkiye'nin siyasi, kültürel ve dini tarihindeki çoğu noktaya 1şık tutacağı aşikârdır. Bu açıdan cumhuriyetin ilk yıllarında izlenen Afganistan'a yönelik politika incelenmeli ve çağın şartlarına göre yeniden yorumlanarak canlandırılmalıdır.

165 “Suriye'deki iç savaşta tecrübe kazanan ve Iran'daki rejim ile bağları güçlenen Şii milislerin gelecekte tekrar Iran'in yönlendirmesiyle hareket edeceği düşünülmektedir. Bu bağlamda Fatimiyyun Tugayı adı altında Suriye'de savaşan binlerce Afgan uyruklu silahlı grubun gelecekte Afganistan'ın güvenliği açısından tehlike arz edeceği de düşünülebilir.” Benzer görüş için bkz. Farzam - Sar1, a.g.m., s. 286. 


\section{Kaynakça}

\section{Kitaplar ve Makaleler}

Afganistan Ülke Raporu, Kabil, T.C. Kabil Büyükelçiliği, Ticaret Müşavirliği, 2017.

Akpınar, Turgut, “Arminius Vambery”, Türkiye Diyanet Vakfi Islam Ansiklopedisi, cilt 42, İstanbul, 2012.

Al-Jaffal, Omar, 'Iraqi Shiites Join Syria War', Al-Monitor, 29 Ekim 2013.

Ansari, Ali - Tabrizi, Aniseh Bassiri, "The View from Tehran”, ed. Aniseh Bassiri Tabrizi - Raffaello Pantucci, Understanding Iran's Role in the Syrian Conflict içinde, Londra, Royal United Services Institute for Defense and Security Studies, Occasional Paper, A ğustos 2016.

Ay, Zahide, "Hazaraların Şiileşmesinde Safevi Etkisi”, Selçuk Üniversitesi Türkiyat Araştırmaları Dergisi, sayı 47, Aralık 2019.

Babür, Gazi Zahirüddin Muhammed, Vekayı Babürün Hatıratı, çev. Reşit Rahmeti Arat, cilt I-II, Ankara, Türk Tarih Kurumu Yayınları, 1987.

Bacon, Elizabeth E., "The Inquiry into the History of the Hazara Mongols of Afghanistan", Southwestern Journal of Anthropology, cilt 7, say1 3, İlkbahar 1951.

Bellew, Henry Walter, The Races of Afghanistan, Calcutta, Thacker-Spink and Co., 1880.

Bilgetürk, İrem, “İran'ın Suriye Politikası Bağlamında Şiilik ve Şii Milisler”, Ankasam, Bölgesel Araştırmalar Dergisi, cilt 2, sayı 2, Aralık 2018.

Burnes, Alexander, Travels into Bokhara I-II, Londra, John Murray, 1839.

Creasy, Jennifer Ruth, "The Religious Identity of the Hazaras of Afghanistan and Modern-day Pakistan", (Yayımlanmamış Yüksek Lisans Tezi), Glasgow, University of Glasgow, Temmuz 2009.

Çelikbilek, Abdül Metin, “Afganistan Emiri Şir Ali Han'ın Modernleşme Çabaları”, Bartın Üniversitesi Çeşm-i Cihan: Tarih, Kültür ve Sanat Araştırmaları E-Dergisi, cilt 4, sayı 2, Kış 2017.

Daftary, Farnad, Muhalif İslam'in 1400 Yll İsmaililer, Tarih ve Kuran, ter. Ercüment Özkaya, İstanbul, Raslantı Yayınları, 1999.

Edwards, Lucy Morgan, "State-building in Afghanistan: a case showing the limits?", International Review of the Red Cross, cilt 92, say1 880, Aralık 2010. 
Elphinstone, Mountstuart, An Account of the Kingdom of Caubul III, Londra, Richard Bentley, 1842.

Farzam, Rahimullah - Sar1, İsmail, "Fatimiyyun: İran'1n Afgan Milisleri”, Selçuk Üniversitesi, Selçuklu Araştırmaları Dergisi, sayı 6, 2017.

Farzan, Ehsanullah, "Afgan Modernleşme Çabalarında Türkçenin Etkisi”, International Journal of Teaching Turkish as a Foreign Language, cilt 2, say1 2, 2019.

Fazlı, Mehmed, Afganistan'a Seyahat, haz. Ali Ahmetbeyoğlu, İstanbul, Selis Kitaplar, 2008.

Ferdinand, Klaus, "Nomad Expansion and Commerce in Central Afghanistan: A Sketch of Some Modern Trends", Folk, cilt 4, 1962.

Ferrier, Joseph Pierre, Caravan Journeys and Wanderings in Persia, Afghanistan, Turkistan and Beloochistan, ed. Henry Danby Seymour, Londra, John Murray, 1857.

Fulton, Will - Holliday, Joseph - Wyer, Sam, Iranian Strategy in Syria, A Joint Report by AEI's Critical Threats Project \& Institute for the Study of War, Institute for the Study of War, Mayis 2013.

Garcistani, Muhammed İsa, Hazara ve Hazaristan, Koveyte, Şura-yi Ferhangi İslami Afganistan Yayınları, 1989.

Gökdağ, Bilgehan Atsız, “Afganistan'da Türklük ve Hazaralar”, Türkler Ansiklopedisi, cilt 20, Ankara, Yeni Türkiye Yayınları, 2002.

Grousset, Rene, Bozkır İmparatorluğu, çev. M. Reşat Uzmen, İstanbul, Ötüken Neşriyat, 1993.

Habibi, Abdulhay, “Aya Hezare Kelime-i Kadimter Est?” Aryana, cilt 20, say1 5, 1962.

Hazır, Tunahan, "Şii Hilai Bağlamında Suriye İç Savaşı ve İran", TURAN-SAM, Turan Stratejik Araştırmalar Merkezi, cilt 11, sayı 43, Yaz 2019.

Holliday, Joseph - Lynch, Michael, "The Battle for Damascus: The Current State of Play," Institute for the Study of War, Aral1k 2012.

Hussain, Muhammed, The Hazaras of Afghanistan: A Study of Ethnic Relations, Quebec, McGill University, 2003.

Kakar, Hassan M., A Political and Diplomatic History of Afghanistan 18631901, Boston, Brill, 2006. 
Karaismailoğlu, Adnan, "Tarih Boyunca Türkler ve Farsça: Modern Yaklaşımlara Bir Eleştiri”, Sosyalbilimler, cilt 3, sayı 1, Ocak 2013.

Kazdal, Melih, “İran'ın Arap Baharı Sonrası Suriye Politikasını Anlamak”, Artuklu Kaime Uluslararası İktisadi ve İdari Araştırmalar Dergisi, cilt 1, sayı 1, 2018.

Kıllıoğlu, Mehmet Erkan, “Türkçe'nin Hint Dillerinin Oluşumuna Olan Etkisi”, Yedi Iklim Dergisi, sayı 224, Kasım 2008.

Komite-i Dini Siyasi ve Ferhengi (Dini, Siyasi ve Kültürel Komite), Cŏgrafya, Kabil, İntişarat-1 Vezaret-i Maarif-i Afghanistan (Afganistan Milli Eğitim Bakanlığı Yayınları), 2011.

Kutay, Cemal, Sahte Derviş, İstanbul, Aksoy Yayıncılık, 1998.

Mirahmedî, Meryem, "Nejad-nâme-i Afgan”, Journal of Historical Research, cilt 1, say1 2, İlkbahar 1989.

Özbay, Müjde Aysun, “İran’ın Şii Hilal Projesi İddiası”, (Yayımlanmamış Yüksek Lisans Tezi), Ankara Üniversitesi, Sosyal Bilimler Enstitüsü, Ankara, 2010.

Özdemir, Çağatay, "Suriyede İç Savaşın Nedenleri: Otokratik Yönetim mi, Bölgesel ve Küresel Güçler mi?”, Bilgi Sosyal Bilimler Dergisi, sayı 2, 2016.

Özgüdenli, Osman Gazi, "Selçuklular”, Türkiye Diyanet Vakfi İslam Ansiklopedisi, cilt 36, İstanbul, 2009.

Özlü, Hüsnü, “'Türk-Afgan Dostluk ve İşbirliği Antlaşması’ Kapsamında Atatürk Dönemi Türkiye-Afganistan İlişkilerine Bakış”, Uluslararası Avrasya Sosyal Bilimler Dergisi, yı1 3, sayı 8, Eylül 2012.

Öz, Mustafa - eş-Şek’a, Mustafa Muhammed, “İsmailiyye”, Türkiye Diyanet Vakfi İslam Ansiklopedisi, cilt 23, İstanbul, 2001.

Pierce, Bryan, "Syria: A Wicked Problem for All”, CTC Sentinel, (Özel Sayı), cilt 6, say1 8, Ağustos 2013.

Poladi, Hasan, The Hazaras, çev. Ali Alemi Kermani, Tahran, İran Yekta Yayınları, H. 1381, (1962).

Prawdin, Michael, The Mongol Empire, New York, The Free Press, 1967.

Sadjadpour, Karim, "Iran's Unwavering Support to Assad's Syria", CTC Sentinel, (Özel Say1), cilt 6, say1 8, Ağustos 2013.

Salihi, Emin, “Ortadoğu'da Oluşan Yeni Dengeler ve 'Şii Hilali' Söylemi””, Bilge Strateji, cilt 2, say1 4, Bahar 2011. 
Saray, Mehmet, Dünden Bugüne Afganistan, İstanbul, Boğaziçi Yayınları, 1981.

, “Afganistan Üzerine Bir Söyleşi”, Afganistan Üzerine Araştırmalar, der. Ali Ahmetbeyoğlu, içinde, İstanbul, Tarih ve Tabiat Vakfı (TATAV) Yayınlar1, 2002.

Schneider, Tobias, "The Fatemiyoun Division: Afghan Fighters in the Syrian Civil War", Middle East Institute, Policy Paper, 2018-9, Washington, Ekim 2018.

Schurmann, Franz, The Mongols of Afghanistan; An Ethnography of the Moghols and Related People of Afghanistan, The Hague, Mouton, 1962.

Sinkaya, Bayram, “İran-Suriye İlişkileri ve Suriye'de Halk İsyanı”, Ortadoğu Analiz, cilt 3, sayı 33, Eylül 2011.

Şeriati, H., Ferhengi Şifahiyi Merdumu Hazara (Cüstari Der Ferhengi Ammeyi Hazarai Afganistan), Kabil, İntişarat-1 Emiri, 2004.

Şeyhanlıŏlu, Hüseyin, “18. Yüzyıldan Günümüze Kadar Afganistan'ın Jeostratejik Önemi”, Avrasya Etüdleri, T.C. Türk İşbirliği ve Kalkınma İdaresi Başkanlığı, sayı 34, sayı 2, 2008.

Thesiger, Wilfred, "The Hazaras of Central Afghanistan", The Geographical Journal, cilt 121, sayı 3, Eylül 1955.

Togan, Ahmet Zeki Velidi, Umumi Türk Tarihine Giriş, İstanbul, Enderun Kitabevi, 1981.

Togçiyeva, Gülhumar, “Hindistan'ın Dudukuşu”, Atatürk Üniversitesi Türkiyat Araştırmaları Enstitüsü Dergisi, sayı 15, 2000.

Türkmen, Erkan, “Emir Husrev-i Dehlevi’nin Urduca'nın Doğuşundaki Rolü”, Selçuk Üniversitesi Edebiyat Fakültesi Dergisi, sayı 2, 1983.

, Emir Hüsrev-i Dehlevi’nin Hayatı, Eserleri ve Edebi Şahsiyeti, Ankara, Atatürk Kültür Dil ve Tarih Yüksek Kurumu, Atatürk Kültür Merkezi Yayın1, say1 29, Türk Fikir ve Sanat Adamları Dizisi, say1 6, 1988.

Ünal, Bekir, “İran'ın Vekâlet Savaşı Stratejisi ve Suriye'deki Şii Milisler”, Bilgesam Analiz, no 1304, 2015.

Vambery, Arminius, Travels in Central Asia, Londra, John Murray, 1864.

Weiers, Michael, "The Language of the Hazara People and of the Mongols of Afghanistan", Afghanistan Journal, cilt 2, say1 3, 1975.

Worth, Robert F., "Effort to Rebrand Arab Spring Backfires in Iran", The New York Times, 2 Şubat 2012. 
Yaylalı, Yasemin, "Emîr Hüsrev-i Dihlevi’nin Bir Gazelinin İncelenmesi", Atatürk Üniversitesi Edebiyat Fakültesi Dergisi, sayı 63, Aralık 2019.

Yazıcı, Orhan, "Hazaraların Kökeni ile İlgili Yeni Bir Görüş”, Türklük Bilimi Araştırmaları, sayı 29, 2011.

Yezdani, Hac Kazım, Defâi Hazaraha Az İstiklal ve Tamamiyeti Arzi-yi Afganistan, Kum, Ahmet İhsani Yayınları, Hicri 1368 (1949).

\section{Çevrimiçi Kaynaklar}

Adeel, Mirwais, "Syrian Rebels Capture 4 Afghans Including Teenager Boys", The Khaama Press News Agency, 23 Nisan 2015, https://www.khaama. com/syrian-rebels-capture-4-afghans-including-teenager-boys-1022/, Erişim tarihi 11.02.2020.

“Afganistan", Anadolu Ajansl, Ülke Profilleri, 05/09/2017, https://www. aa.com.tr/tr/ulke-profilleri/afganistan/901494, Erişim tarihi 15.07.2020.

“Afganistan'da 23 Y1l Sonra Nüfus Sayımı”, Hürriyet, 01 Eylül 2002, https:// www.hurriyet.com.tr/dunya/afganistanda-23-yil-sonra-nufus-sayimi-94899, Erişim tarihi 08.05.2020.

Alfoneh, Ali, "Shia Afghan Fighters in Syria", Atlantic Council, 19 Nisan 2017, https://www.atlanticcouncil.org/blogs/syriasource/shia-afghan-fighters-insyria/, Erişim tarihi 12.03.2020.

Alparslan, Hasan, “Unutulan Hazara Türkleri”, Bakış Gazetesi, http://www. bakisgazetesi.com/makale/hasan-alparslan/-unutulan-hazara-turkleri/544.html, Erişim tarihi 08.02.2020.

Başar, Utku, “Şii Hilali' Gerçek Oldu!”, CNN Türk, 10.03.2015, https:// www.cnnturk.com/yazarlar/guncel/utku-basar/sii-hilali-gercek-oldu, Erişim tarihi 02.08.2020.

"Bibi” Türk Dil Kurumu Sözlükleri, https://sozluk.gov.tr/?kelime=BAKIRSI, Erişim tarihi 21.05.2020.

"BMP-1", Wikipedia, https://en.wikipedia.org/wiki/BMP-1, Erişim tarihi 15.07.2020.

Bouckaert, Peter, “Europe's Refugee Crisis Isn't Only About Syria”, Foreign Policy, 18 Ekim 2015, https://foreignpolicy.com/2015/09/18/europes-refugeecrisis-isnt-only-about-syria-iraq-afghans/, Erişim tarihi 14.06.2020.

"Büyük Selçuklu İmparatorluğu”, Vikipedia, https://tr.wikipedia.org/ wiki/B\%C3\%BCy\%C3\%BCk_Sel\%C3\%A7uklu_\%C4\%B0mparatorlu\%C4\%- 
9Fu\#Devlet_Yap\%C4\%B1s\%C4\%B1_ve_Y\%C3\%B6netimi, Erişim tarihi 18.05.2020.

Coghlan, Tom, Aimal Yaqubi, ve Sara Elizabeth Williams, "Assad Recruits Afghan Mercenaries to Fight Isis," The Times, 2 Haziran 2015, https://www.thetimes.co.uk/article/assad-recruits-afghan-mercenaries-to-fight-isis-rzvp3bh2fhh, Erişim tarihi 15.07.2020.

Conrad, Naomi, "Iran recruits Afghan teenagers to fight war in Syria", Deutsche Welle, 5 May1s 2018, https://www.dw.com/en/iran-recruits-afghan-teenagers-to-fight-war-in-syria/a-43634279, Erişim tarihi 15.07.2020.

Constable, Pamela, "Recruited by Iran to Fight for Syrian Regime, Young Afghans Bring Home Cash and Scars", The Washington Post, 29 Temmuz 2018, https://www.washingtonpost.com/world/asia_pacific/recruited-by-iran-tofight-for-syrian-regime-young-afghans-bring-home-cash-and-scars/2018/07/29/ ecf9e34c-64e0-11e8-81ca-bb14593acaa6_story.html, Erişim tarihi 28.04.2020.

Esfandiari, Golnaz, "Increasing Number Of Afghans, Pakistanis Killed In Syria Buried In Iran", Radio Free Europe, Radio Liberty, 25 Nisan 2015, https:// www.rferl.org/a/persian-letters-afghans-pakistanis-killed-fighting-in-syria-for-iran/26977907.html, Erişim tarihi 24 Ocak 2020.

Fassihi, Farnaz, "Iran Pays Afghans to Fight for Assad, Offers Them $\$ 500$ Stipend, Residency Benefits", The Wall Street Journal, 22 May1s 2014, https:// www.wsj.com/articles/iran-recruiting-afghan-refugees-to-fight-for-regime-in-syria-1400197482, Erişim tarihi 11.02.2020.

Goodarzi, Jubin, Iran and Syria, The Iran Primer, United States Institute of Peace, 2010, https://iranprimer.usip.org/resource/iran-and-syria, Erişim tarihi 28.05.2020.

Gökdağ, Bilgehan Atsız, “Afganistan'da Türklük ve Hazaralar”, Tarih Tarih, https://www.tarihtarih.com/?Syf=26\&Syz=358890, Erişim tarihi 12.05.2020.

Homsi, Nada, “Afghan Teenagers Recruited in Iran to Fight in Syria, Group Says", The New York Times, 1 Ekim 2017, https://www.nytimes.com/2017/10/01/ world/middleeast/iran-afghan-child-soldiers-syria-war.html, Erişim tarihi 15.07.2020.

Hüseyni, Hüda, 'Fatımiyyun' Tugayı ABD ile Yüzleşmek için Suriye’yi Terk Ediyor", Şarkul Avsat, 6 Haziran, 2019, https://aawsat.com/turkish/ home/article/1755586/h\%C3\%BCda-huseyni/\%E2\%80\%98fat $\%$ C4\%B 1 miyyun $\%$ E2\%80\%99-tugay $\%$ C4\%B 1-abd-ile-\%C3\%BCzle $\%$ C5\%9Fmek-i\%C3\%A7in-suriye\%E2\%80\%99yi-terk-ediyor, Erişim tarihi 15.07.2020. 
"Iran: Afghan Children Recruited to Fight in Syria", Human Rights Watch, 1 Ekim 2017, https://www.hrw.org/news/2017/10/01/iran-afghan-children-recruited-fight-syria, Erişim tarihi 15.07.2020.

"Iran Sending Thousands of Afghans to Fight in Syria," Human Rights Watch, 29 Ocak 2016, https://www.hrw.org/news/2016/01/29/iran-sending-thousands-afghans-fight-syria, Erişim tarihi 14.06.2020.

Jamal, Ahmad Shuja, "Syria's Afghan Refugees Trapped in Double Crisis", UN Dispatch, United Nations News and Commentary, Global News Forum, 28 Ocak 2013, https://www.undispatch.com/syrias-afghan-refugees-trapped-in-adouble-crisis/, Erişim tarihi 06.03.2020.

, "Mission accomplished? What's next for Iran's Afghan fighters in Syria", War on the Rocks, 13 Şubat 2018, https://warontherocks.com/2018/02/ mission-accomplished-whats-next-irans-afghan-fighters-syria/, Erişim tarihi 12.05.2020.

Jedinia, Mehdi ve Noor Zahid, "Iran Continues Deporting Undocumented Afghan Refugees", Voice of America, 21 May1s 2017, https://www.voanews.com/ extremism-watch/iran-continues-deporting-undocumented-afghan-refugees, Erişim tarihi 14.06.2020.

Kalafat, Yaşar, "İsmaili Hazara Türkleri”, Yeniden Ergenekon, 19 Haziran 2008, https://yenidenergenekon.com/274-ismaili-hazara-turkleri/, Erişim tarihi 12.05.2020.

Kenner, David, “Afghan Militants Join Syria's Civil War, As If It Wasn't Awful Enough", Foreign Policy, 4 Aralk 2013, https://foreignpolicy.com/2013/12/04/ afghan-militants-join-syrias-civil-war-as-if-it-wasnt-awful-enough/, Erişim tarihi 11.02.2020.

"Kişi Başına Nominal GSYİH Değerlerine Göre Ülkeler Listesi”, Vikipedia, https://tr.wikipedia.org/wiki/Ki\%C5\%9Fi_ba\%C5\%9F\%C4\%B1na_nominal_ GSY\%C4\%B0H_de\%C4\%9Ferlerine_g\%C3\%B6re_\%C3\%BClkeler_listesi, Erişim tarihi 15.07.2020.

Lamer, Wiebke ve Erin Foster, "Afghan Ethnic Groups: A Brief Investigation", Afghanistan Thematic Report, NATO Civil-Military Fusion Center (CFC), Ağustos 2011.

Latifi, Ali M., "How Iran Recruited Afghan Refugees to Fight Assad's War," The New York Times, 30 Haziran 2017, https://www.nytimes.com/2017/06/30/ opinion/sunday/iran-afghanistan-refugees-assad-syria.html, Erişim tarihi 14.06.2020. 
Loveluck, Louisa, "The Battle for Aleppo, Explained", The Washington Post, 24 Kasim 2016, https://www.washingtonpost.com/news/worldviews/ wp/2016/11/24/the-battle-for-aleppo-explained/, Erişim tarihi 15.07.2020.

Majidyar, Ahmad, "Afghan Officials in Deep Water After Praising Role of Soleimani and Shiite Militias in Syria", Middle East Institute, 29 Kasim 2017, https:/www.mei.edu/publications/afghan-official-deep-water-after-praising-role-soleimani-and-shiite-militias-syria, Erişim tarihi 15.07.2020.

Moslih, Hashmatallah, “Iran 'Foreign Legion' Leans on Afghan Shia in Syria War”, Al Jazeera, 22 Ocak 2016, https://www.aljazeera.com/news/2016/01/ iran-foreign-legion-leans-afghan-shia-syria-war-160122130355206.html, Erişim tarihi 06.08.2020.

Muhammedi, Abdullah, "Hazaralar' in Tarihi ve Etnolojik Yapıs1”, 08.01.2009, https:/guneyturkistan.wordpress.com/2009/01/08/hazaralarin-tarihi-ve-etnolojik-yapisi/, Erişim tarihi 08.02.2020.

Neriah, Jacques, "Iran Deploys Afghan Shiite Brigade to Spread Its Control in Southern Syria", 4 Mart 2015, Jerusalem Center for Public Affairs, https:// jcpa.org/iran-shiite-brigade-syria/, Erişim tarihi 12.05.2020.

Oğuz, Gamze Türkoğlu, "HRW: İran, Suriye'de Afgan Göçmen Çocukları Savaştırıyor", Anadolu Ajansı, 1 Ekim 2017, https://www.aa.com.tr/tr/dunya/ hrw-iran-suriyede-afgan-gocmen-cocuklarini-savastiriyor/924166, Erişim tarihi 14.06.2020.

Peterson, Scott, "Iran Steps up Recruitment of Shiite Mercenaries for Syrian War", The Chiristian Science Monitor, 12 Haziran 2016, https://www.csmonitor. com/World/Middle-East/2016/0612/Iran-steps-up-recruitment-of-Shiite-mercenaries-for-Syrian-war, Erişim tarihi 15.07.2020.

Polk, William R., "Understanding Syria: From Pre-Civil War to Post-Assad", The Atlantic, 10 Mart 2013, https:/www.theatlantic.com/international/archive/2013/12/understanding-syria-from-pre-civil-war-to-post-assad/281989/, Erişim Tarihi 22.10.2020.

Rasmussen, Sune Engel - Nader, Zahra, "Iran Covertly Recruits Afghan Shias to Fight in Syria," The Guardian, 30, Haziran 2016, https://www.theguardian. com/world/2016/jun/30/iran-covertly-recruits-afghan-soldiers-to-fight-in-syria, Erişim Tarihi: 12.05.2020.

Reuter, Christoph, "Murad's War: An Afghan Face to the Syrian Conflict", Afghanistan Analysts Network, 26 Haziran 2015, https://www.afghanistan-a- 
nalysts.org/murads-war-an-afghan-face-to-the-syrian-conflict/, Erişim tarihi 24 Ocak 2020.

"Russia Trains Iran-sponsored Shia Militias in Syria", Afghanistan Analysis, 1 Aralık 2017, https://afghanistananalysis.wordpress.com/2017/12/01/russia-trains-iran-sponsored-shia-militias-in-syria/, Erişim tarihi 15.07.2020.

Sahraei, Fariba, "Syria War: The Afgans Sent by Iran to Fight for Assad", $B B C$, 15 Nisan 2016, https:/www.bbc.com/news/world-middle-east-36035095, Erişim tarihi 12.05.2020.

Seligman, Lara, “The Child Soldier Crisis: 'Kids Are Cheap", Foreign Policy, Report, 8 Kasım 2019, https://foreignpolicy.com/2019/11/08/child-soldier-crisis-kids-are-cheap-yemen-isis-my-star-sky/, Erişim tarihi 15.07.2020.

Smyth, Philip, "Iran's Afghan Shiite Fighter in Syria", The Washington Institute, Policy Watch 2262, 3 Haziran 2014, https://www.washingtoninstitute. org/policy-analysis/view/irans-afghan-shiite-fighters-in-syria, Erişim tarihi 11.02.2020.

Strickland, Patrick, "Why Are Afghan Refugees Leaving Iran?", Al Jazeera, 17 Mayis 2016, https:/www.aljazeera.com/indepth/features/2016/05/afghan-refugees-leaving-iran-160511103759873.html, Erişim tarihi 14.06.2020.

Surosh, Esmatullah, “Afganistan'ın Etnik Grupları Arasındaki Çatışmaların Temel Nedenlerinin Analizi”, 14/01/2018, Kafkasya Stratejik Araştırmalar Merkezi-Kafkassam, https://kafkassam.com/afganistanin-etnik-gruplar-arasindaki-catismalarin-temel-nedenlerinin-analiz.html, Erişim tarihi 12.05.2020.

Thomas, Joscelyn, “Islamic State's Khorasan 'Province' Claims Responsibility for Attack on Cultural Center in Kabul," FDD's Long War Journal, 28 Aral1k 2017, https://www.longwarjournal.org/archives/2017/12/islamic-states-khorasan-province-claims-responsibility-for-attack-on-cultural-center-in-kabul.php, Erişim tarihi 13.03.2020.

Toplu, Mehmet, "Hazara Türklerinin Geçmişi ve Bugünü”, Azərbaycanlıların va Digər Türkdilli Xalqların Đməkdaşlıq Mərkəzi, (ATХӘM), 19 Ekim 2016, http://atxem.az/news/a-15486.html, Erişim tarihi 25.02.2020.

“Ülkelerin Kişi Başına Düşen Milli Gelirleri”, Sabah, 19.04.2011, https:// www.sabah.com.tr/galeri/ekonomi/ulkelerin-kisi-basina-dusen-milli-gelirleri, Erişim tarihi 15.07.2020.

Williams, Sara Elizabeth, "Afghan Fighters an Increasingly Significant Player on Syrian Battlefield”, Midlle East Eye, 22 Haziran 2015, https://www.midd- 
leeasteye.net/news/afghan-fighters-increasingly-significant-player-syrian-battlefield, Erişim tarihi 11.02.2020.

Wright, Robin, “The Battle For Aleppo, Syria's Stalingrad, Ends”, The New Yorker, 13 Aralık 2016, https://www.newyorker.com/news/news-desk/the-battle-for-aleppo-syrias-stalingrad-ends , Erişim tarihi 15.07.2020.

"Yoksulluğun Maliyeti 40 Milyar Dolar", Hürriyet, 21 Temmuz 2010, https:// www.hurriyet.com.tr/gundem/yoksullugun-maliyeti-40-milyar-dolar-15361941, Erişim tarihi 15.07.2020. 